\title{
Geology of the Devonian Marcellus Shale-Valley and Ridge Province, Virginia and West Virginia- A Field Trip Guidebook for the American Association of Petroleum Geologists Eastern Section Meeting, September 28-29, 2011
}

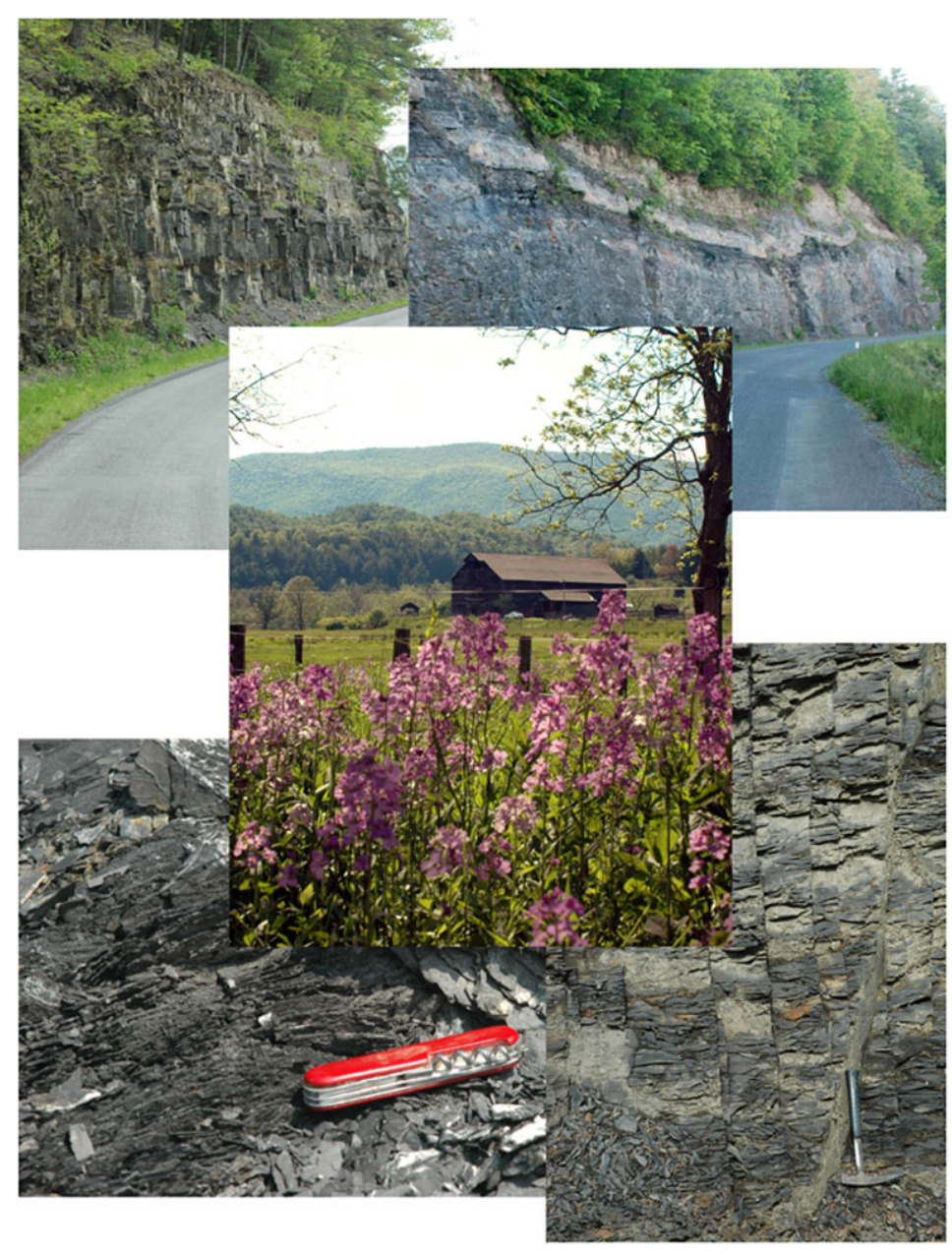

Open-File Report 2012-1194 


\section{Geology of the Devonian Marcellus Shale-Valley and Ridge Province, Virginia and West Virginia- A Field Trip Guidebook for the American Association of Petroleum Geologists Eastern Section Meeting, September 28-29, 2011}

By Catherine B. Enomoto ${ }^{1}$, James L. Coleman, Jr. ${ }^{1}$, John T. Haynes ${ }^{2}$, Steven J. Whitmeyer ${ }^{2}$, Ronald R. McDowell ${ }^{3}$, J. Eric Lewis ${ }^{3}$, Tyler P. Spear ${ }^{3}$, and Christopher S. Swezey ${ }^{1}$

'U.S. Geological Survey, Reston, VA 20192

2James Madison University, Harrisonburg, VA 22807

${ }^{3}$ West Virginia Geological and Economic Survey, Morgantown, WV 26508

Open-File Report 2012-1194 


\section{U.S. Department of the Interior \\ Ken Salazar, Secretary}

\section{U.S. Geological Survey \\ Marcia K. McNutt, Director}

U.S. Geological Survey, Reston, Virginia: 2012

For product and ordering information:

World Wide Web: http://www.usgs.gov/pubprod

Telephone: 1-888-ASK-USGS

For more information on the USGS-the Federal source for science about the Earth, its natural and living resources, natural hazards, and the environment:

World Wide Web: http://www.usgs.gov

Telephone: 1-888-ASK-USGS

Any use of trade, product, or firm names is for descriptive purposes only and does not imply endorsement by the U.S. Government.

Although this report is in the public domain, permission must be secured from the individual copyright owners to reproduce any copyrighted material contained within this report.

Suggested citation:

Enomoto, C.B., Coleman, J.L., Jr., Haynes, J.T., Whitmeyer, S.J., McDowell, R.R., Lewis, J.E., Spear, T.P., and Swezey, C.S., 2012, Geology of the Devonian Marcellus Shale-Valley and Ridge province, Virginia and West Virginia_-A field trip guidebook for the American Association of Petroleum Geologists Eastern Section Meeting, September 28-29, 2011: U.S. Geological Survey Open-File Report 2012-1194, 55 p., available only at http://pubs.usgs.gov/of/2012/1194/. 
American Association of Petroleum Geologists Eastern Section Meeting

September 25-27, 2011

Field Trip: Geology of the Devonian Marcellus Shale_-Valley and Ridge Province, Virginia and West Virginia

September 28-29, 2011

Trip Leaders:

James L. Coleman, Jr., and Catherine B. Enomoto

U.S. Geological Survey

Reston, Virginia

And

John T. Haynes and Steven J. Whitmeyer

James Madison University

Harrisonburg, Virginia

And

Ronald R. McDowell and J. Eric Lewis

West Virginia Geological and Economic Survey

Morgantown, West Virginia 


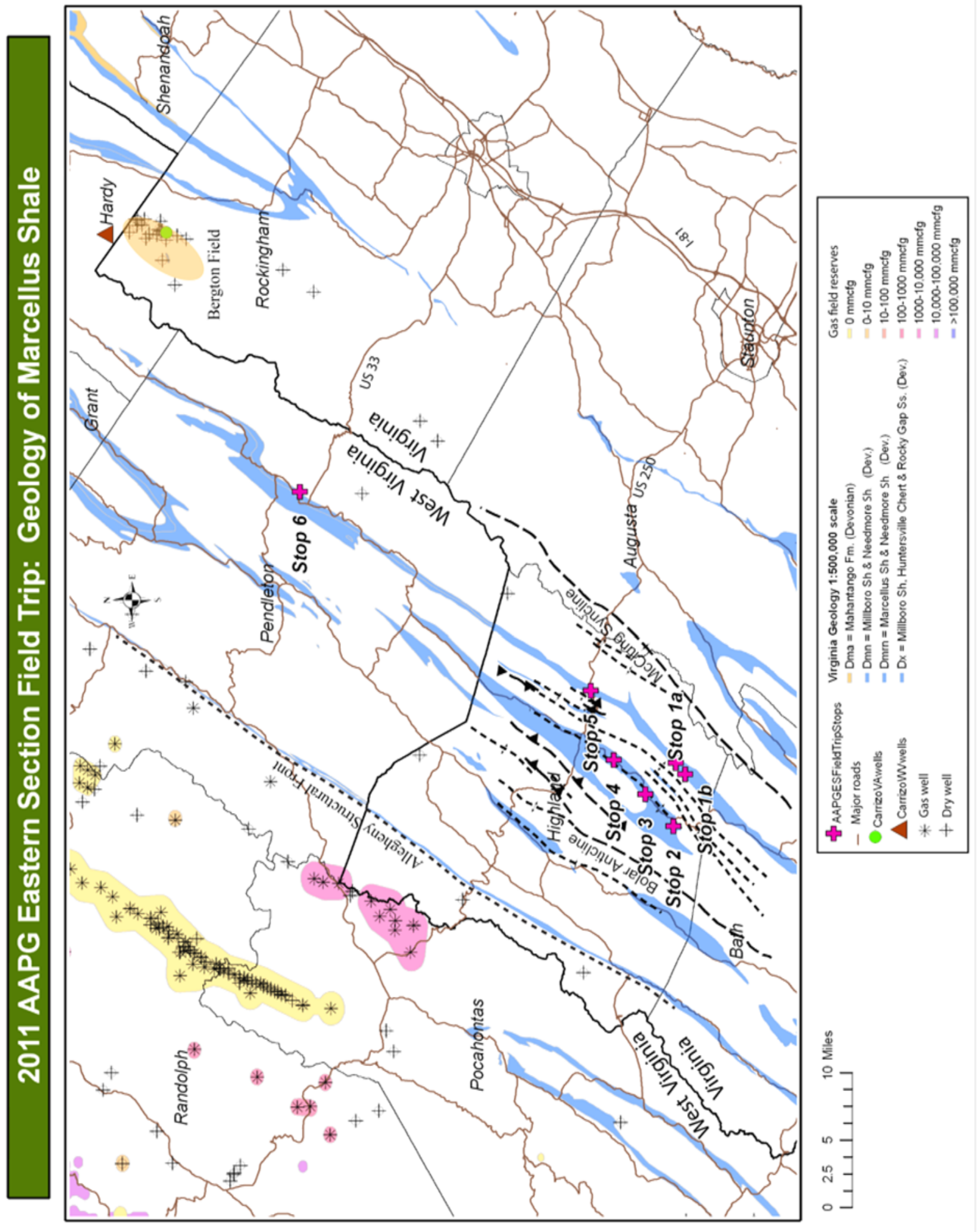




\section{Itinerary}

Wednesday, September 28

Leave Crystal City

8:00 a.m.

Rest stop: Harrisonburg

10:00 a.m.

Lunch stop: Mountain Home Picnic Area,

11:30 a.m.

Near Ramsey's Draft

George Washington National Forest

Lunch provided, picnic tables, restrooms

Overview of field trip by Jim Coleman

Topics: Regional stratigraphy, regional structure

History of Bergton field, gross well log correlations

Leave lunch stop

12:30 p.m.

Arrive Stop 1a and 1b: Cowpasture River (S.R. 614)

1:15 p.m.

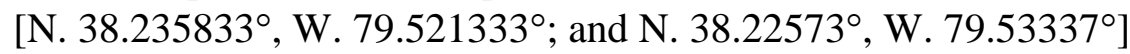

Steve Whitmeyer and John Haynes

Topics: Details of past research: structure, stratigraphy, joints, undeformed versus crumpled zone, petrography

Leave Stop 1b

2:45 p.m.

Arrive Stop 2: Flood (S.R. 609)

3:15 p.m.

[N. 38.238017 ${ }^{\circ}$, W. $79.589133^{\circ}$ ]

Jim Coleman

Topics: Stratigraphy, structural position

Leave Stop 2

3:35 p.m.

Arrive Stop 3: Clover Creek South (S.R. 678)

[N. 38.2678 ${ }^{\circ}, \mathrm{W} .79 .55473^{\circ}$ ]

Jim Coleman and John Haynes

Topics: Details of past research: stratigraphy, geochemistry, concretions

Leave Stop 3

4:10 p.m.

Arrive Hotel

5:00 p.m.

Highland Inn and Montvallee Motel, Monterey, Va.

Dinner buffet at Highland Inn

5:30 - 7:30 p.m. 
Thursday, September 29

Continental breakfast at Highland Inn

$7: 30-8: 15$ a.m.

(full-service breakfast is available nearby at additional cost)

Leave Monterey

8:30 a.m.

Arrive Stop 4: Bullpasture River (S.R. 678)

9:00 a.m.

[N. 38.301483 ${ }^{\circ}$, W. $79.5179^{\circ}$ ]

Jim Coleman and John Haynes

Topics: Intraformational structures, stratigraphy, jointing, geochemistry, petrography (limestone versus barite)

Leave Stop 4

9:45 a.m.

Arrive Stop 5: Bullpasture Mountain (U.S. 250)

10:15 a.m.

[N. 38.3255', W. 79.443617

Cathy Enomoto and Jim Coleman

Topics: Details of research: geochemistry, mineralogy, stratigraphy

Leave Stop 5

11:15 a.m.

Arrive lunch stop: Brandywine, W.Va.

12:00 p.m.

Leave lunch stop

1:00 p.m.

Arrive Stop 6: Brandywine, W.Va. (U.S. 33)

1:05 p.m.

[N. 38.6337 ${ }^{\circ}$, W. 79.2313]

Ron McDowell and Eric Lewis

Topics: Upper Millboro Shale, depositional environment

Leave Stop 6

2:00 p.m.

Rest stop: Harrisonburg, Va.

2:45 p.m.

Arrive Crystal City

6:00 p.m. 


\title{
Geology of the Devonian Marcellus Shale_-Valley and Ridge Province, Virginia and West Virginia
}

\author{
By Catherine B. Enomoto, James L. Coleman, Jr., John T. Haynes, Steven J. Whitmeyer, \\ Ronald R. McDowell, J. Eric Lewis, Tyler P. Spear, and Christopher S. Swezey
}

\begin{abstract}
Detailed and reconnaissance field mapping and the results of geochemical and mineralogical analyses of outcrop samples indicate that the Devonian shales of the Broadtop Synclinorium from central Virginia to southern Pennsylvania have an organic content sufficiently high and a thermal maturity sufficiently moderate to be considered for a shale gas play. The organically rich Middle Devonian Marcellus Shale is present throughout most of the synclinorium, being absent only where it has been eroded from the crests of anticlines. Geochemical analyses of outcrop and well samples indicate that hydrocarbons have been generated and expelled from the kerogen originally in place in the shale. The mineralogical characteristics of the Marcellus Shale samples from the Broadtop Synclinorium are slightly different from the averages of samples from New York, Pennsylvania, northeast Ohio, and northern West Virginia. The Middle Devonian shale interval is moderately to heavily fractured in all areas, but in some areas substantial fault shearing has removed a regular "cleat" system of fractures.

Conventional anticlinal gas fields in the study area that are productive from the Lower Devonian Oriskany Sandstone suggest that a continuous shale gas system may be in place within the Marcellus Shale interval at least in a portion of the synclinorium. Third-order intraformational deformation is evident within the Marcellus shale exposures. Correlations between outcrops and geophysical logs from exploration wells nearby will be examined by field trip attendees.
\end{abstract}

\section{Acknowledgments}

The authors thank Patrick W. Niemeyer, U.S. Geological Survey, for his contributions to this project, which included field mapping, sample collection, and log digitization. We thank Diana L. Rotter, U.S. Geological Survey, for her contributions, including sample collection and sample descriptions. Also, the authors greatly appreciate the thoughtful comments by the technical reviewers: Matthew Heller, Virginia Division of Geology and Mineral Resources, and John Repetski, U.S. Geological Survey.

\section{Introduction}

Within the Devonian System of the central Appalachians, a transition from a stable shallow marine platform to a foreland basin is evident from stratigraphic changes that occur as carbonate rocks of the Lower Devonian Helderberg Group and the quartz arenite of the overlying 
Lower Devonian Oriskany Sandstone pass upward into deeper water slope and basin margin shales and turbidites of the Needmore Shale, Marcellus Shale, Mahantango Formation (the Millboro Shale where Marcellus Shale and Mahantango Formation cannot be differentiated), and Brallier Formation (Lundegard and others, 1985; Dorobek and Read, 1986; Woodrow and others, 1988). This significant change in depositional regime had eustatic, climatic, and tectonic causes.

The initial eustatic influence is evident within the Oriskany Sandstone, a subrounded- to rounded-, fine- to medium-grained, medium-bedded quartz sandstone that is highly fossiliferous in some intervals (Cecil and others, 2004). The Oriskany is believed to have been deposited as a deltaic to coastal sand body during sea level fall. Cross-bedding and disarticulated brachiopod valves indicate a current-swept, shallow marine depositional environment. Alternatively, the rounded quartz grains may have resulted from windblown deposition into a carbonate environment (Grabau, 1940; Cecil and others, 1991, 2004). Or, it is possible that during a highly arid period, low efficiency but large drainage systems may have occasionally brought highly mature sands from the hinterland (somewhere currently in either Europe or Africa) to an arid coastline similar to the present-day Namibian coastline. Minor coastal currents and storms may have helped spread the sand into sheet-like deposits within a carbonate environment. The shell material appears to have dissolved and reprecipitated as carbonate cement into intergranular pore space (Cecil and others, 2004), lithifying the sandstone. The capping ironstone crust at (and near) the top of the Oriskany may represent a maximum flooding surface, which developed on the sand sheets after a sea level rise, prior to the onset of the Needmore Shale prodelta or Onondaga Limestone carbonate bank deposition. The Huntersville Chert may represent a lithologic transition between the Onondaga and the Needmore, or it may represent the distal vestiges of the eolian transport system for the original Oriskany windblown sand (Cecil, 2004a, b). The Oriskany is the only Devonian sandstone in the Appalachian basin that extends west of the basin axis (Dennison and Head, 1975), and it is generally believed to be equivalent to the Dutch Creek Sandstone of the Illinois Basin and the Sylvania Sandstone of the Michigan Basin (Swezey, 2008, 2009).

A climatic influence is suggested by the widespread presence of carbonate banks, chert of the Helderberg Group, extremely pure quartz sandstone of the Oriskany Sandstone underlying silty shale of the Needmore Shale, and organic-rich shale of the Millboro Shale containing predominantly Type II kerogen (Cook and Bally, 1975; Hill and Lombardi, 2002; Ryder and others, 2011). A model for the influence of paleoclimate on Carboniferous deposition in North America (for example, Scotese, 2003; Cecil, 2009) may be applicable to the Devonian strata. The tectonic influence is evident with the development and evolution of the Acadian foredeep at the end of Oriskany deposition as collision between a microplate or island arc and the southeastern margin of Laurentia occurred. Ultimately, the collision led to the Acadian Orogeny and deposition of the Catskill clastic wedge throughout the central Appalachians (Woodrow and Sevon, 1985).

Of particular interest to the field trip stops are the changes in depositional environments that occurred with the successive formation of the Oriskany Sandstone, the Needmore Shale, the Marcellus Shale and Mahantango Formation. The occurrence of limestone concretion beds, limestone beds, and barite-rich deposits within the Millboro Shale will be examined and discussed, as will results of geochemical analyses and mineralogical studies. Changes in deformation styles between the Marcellus Shale and the overlying and underlying formations will be examined as well. 


\section{Stratigraphy}

\section{Oriskany Sandstone}

The Oriskany Sandstone (Vanuxem, 1839, for Oriskany Falls, New York; fig. 1) is the oldest of the Devonian stratigraphic units that we will study at the stops. It is typically 10-25 meters (m) thick in the Cowpasture and Bullpasture River valleys. At one exposure in Hupman Valley it is only 3-4 m thick (Haynes and Whitmeyer, 2010). It is characteristically a medium- to thick-bedded, fossiliferous, white quartz arenite that weathers to various shades of light yellowish-gray, commonly with rusty, probably limonitic, stains. It is medium- to coarse-grained ( $\mathrm{mU}$ to $\mathrm{cL}$ ) with a few thinner zones of coarser quartz sand, and even some granules and pebbles. Moldic pores of large brachiopods including Spirifer arenosus are common in some horizons of the Oriskany, and it is these pores along with remnant primary and (or) secondary (from dissolution of calcite cement) interparticle porosity that have allowed the Oriskany to be a prolific oil and gas producer in many areas of the Appalachian basin (Diecchio, 1985), including the Thornwood field along the Highland County, Va. - Pocahontas County, W.Va., border (Limerick and others, 2005). The nearest Oriskany field to the field trip area is the Bergton field in northwestern Rockingham County, Va. (Young and Harnsberger, 1955; Limerick and others, 2005).

The contact of the Oriskany Sandstone with the underlying Licking Creek Limestone, or facies-equivalent Shriver Chert (Dorobek and Read, 1986; Haynes and Whitmeyer, 2010), is visible along U.S. 250 on the east flank of Bullpasture Mountain and in Hupman Valley where an access road crosses a small stream. The contact may also be observed in some caves and sinkholes south of the settlement of Flood, at several places in the gorge of the Bullpasture River, and on a bluff on the west bank of the Cowpasture River south of the settlement of Patna.

The contact of the Oriskany with the overlying Needmore Shale is visible on the south side of an old meander scar of the Cowpasture River southeast of the community of Patna (see figs. 6-7, near stop 1a), and along S.R. 609 southwest of the church at Flood (figs. 6-7, near stop 2). Although the Oriskany Sandstone usually weathers to friable sandstone, the disconformity at the top of the Oriskany is sometimes characterized by a hard, mineralized interval stained with iron, as seen on U.S. 250 near stop 5 (see figs. 34-35).

\section{Needmore Shale and Huntersville Chert}

The Needmore Shale (Willard, 1939) is typically 20-35 m thick and is a greenish-gray mudrock that weathers to various shades of light gray to olive gray or greenish gray. In nearly all exposures it contains a diverse and moderately abundant marine fauna of whole and fragmental corals, brachiopods, trilobites (notably Phacops sp.), bryozoans, crinoids, and ostracodes. In exposures in this region there is dark-gray shale at the base of the Needmore that is normally only 1-2 m thick; this is the Beaver Dam Shale Member, named and first described by Willard (1939). The Needmore spans the Early to Middle Devonian boundary. At some locations in this region, there is cherty sandstone between the Needmore Shale and the Oriskany Sandstone. This cherty sandstone may represent the northeasternmost extent of the facies-equivalent Huntersville Chert (Bick, 1962), an important gas producer in southern West Virginia (Patchen, 1968; Cardwell, 1982).

The contact of the Needmore with the overlying Millboro Shale can be observed in the dry riverbed of the Cowpasture River north of Laurel Gap and along the bluff on the south side of the aforementioned meander scar of the Cowpasture River. 


\section{Millboro Shale}

The Millboro Shale (first used by Cooper, 1939, with formal introduction by Butts, 1940) is a 300- to 400-m-thick sequence of primarily mudrock including black fissile shales, thinly laminated and thin-bedded black shales, and very fine grained siltstones that weather yellowgray to white to silvery and are sparsely fossiliferous, with a few small brachiopods and occasional ammonoids being the most commonly recovered fossils. The Millboro also contains prominent zones of calcareous concretions that range in diameter from 2 centimeters $(\mathrm{cm})$ to more than $1 \mathrm{~m}$. Some of these are septarian in character (Lesure, 1957), and authigenic barite and quartz are common in many concretions as well as in some discrete beds (Nuelle and Shelton, 1986; Clark and Mosier, 1989).

In the parallel valleys of the Cowpasture and Bullpasture Rivers, separated by Bullpasture Mountain, the Millboro Shale occurs along the axes of synclines. It is also exposed in a tight syncline present in the Hupman Valley, which divides Bullpasture Mountain into two parallel ridge crests. Mahantango Formation, or Upper Millboro, is recognized on the east side of the Cowpasture River near U.S. 250. The contact with the Brallier Formation is not exposed but likely is located on the west flank of Shaw's Ridge.

North of the field trip area, the Marcellus Shale is distinguished from the Mahantango Formation, and "Millboro Shale" is not used.

\section{Marcellus Shale}

The Marcellus Shale (Hall, 1839) consists of dark-gray to black, fissile, pyritic shale interbedded with dark-gray argillaceous limestone or calcareous shale. It contains a fossiliferous layer of limestone, the Purcell Member of the Marcellus Shale (Cate, 1963), and prominent zones of calcareous concretions ranging in diameter from several centimeters to more than $1 \mathrm{~m}$. In the study area, it often exhibits chaotic bedding. The Marcellus Shale is about $165 \mathrm{~m}$ thick in western Shenandoah County (Rader and Gathright, 2001), where it is differentiated from the Mahantango Formation.

The Marcellus Shale has been identified in the subsurface using geophysical well logs in Highland and Rockingham Counties, Va., and in Pocahontas and Pendleton Counties, W.Va., and from conodonts collected from surface samples in Shenandoah County, Va. (Harris and others, 1994). However, this geologic unit is not differentiated on all published geologic maps in westernmost Virginia southwest of Shenandoah County and northeast of Buchanan County (Rader and Wilkes, 2001; Dicken and others, 2005) nor in easternmost West Virginia from western Pendleton County south to Monroe County (Hasson and Dennison, 1968; Nicholson and others, 2005). In these areas, the term Millboro Shale is often used for the dark-gray to black fissile shale found in outcrop where no distinction can be made with the overlying Mahantango Formation.

Dennison (2005) and subsequent studies by the U.S. Geological Survey (USGS) suggest that the Purcell Member of the Marcellus Shale is present in the exposure on U.S. 250 east of McDowell and on S.R. 678 along the Bullpasture River. Recent mapping in the Williamsville 7.5-minute quadrangle (Haynes and Whitmeyer, 2010) suggests that the Purcell Member is present as disaggregated and separated beds in the deformed regions of the Cowpasture riverbed. Conodont biostratigraphy indicates the Purcell in the Winchester 30 x 60 minute quadrangle is of Middle Devonian (Eifelian) age (Harris and others, 1994). In the exposure on U.S. 250, the unit consists of about $12 \mathrm{~m}$ of cross-laminated tan, silty, calcareous shale and gray, fossiliferous, silty limestone. Nuelle and Shelton (1986) recognized the Purcell Member as a favorable target for barite exploration. 


\section{Mahantango Formation}

The Mahantango Formation (Willard, 1935) consists of thin-bedded to laminated gray shales, greenish-gray siltstones, and fine-grained, greenish-gray sandstones. Where examined in the study area, the Mahantango has low total organic content and regular (that is, non-chaotic) bedding. As noted above, locally the Mahantango is difficult to distinguish from the underlying Marcellus Shale, and therefore these formations are often combined and mapped as one unit called the Millboro Shale in westernmost Virginia and easternmost West Virginia (de Witt and others, 1993).

\section{Brallier Formation}

The Brallier Formation (Butts, 1918) is 300 to $550 \mathrm{~m}$ of interbedded dark-gray to greenish-gray shales, siltstones, and sandstones within the area of the Staunton $30 \times 60$ minute quadrangle (Rader and Wilkes, 2001), including Highland County, Va. The grain size increases upward in section, and sandstones become more abundant in the upper portion of the formation. The base of the Brallier is placed at the top of the gray to black shales of the Millboro Shale or at the top of a thick sandstone unit of the underlying Mahantango Formation in Highland County (Rader and Wilkes, 2001), and it has a sharp contact with the underlying Millboro Shale in Pendleton County, W.Va. (McDowell and others, 2007).

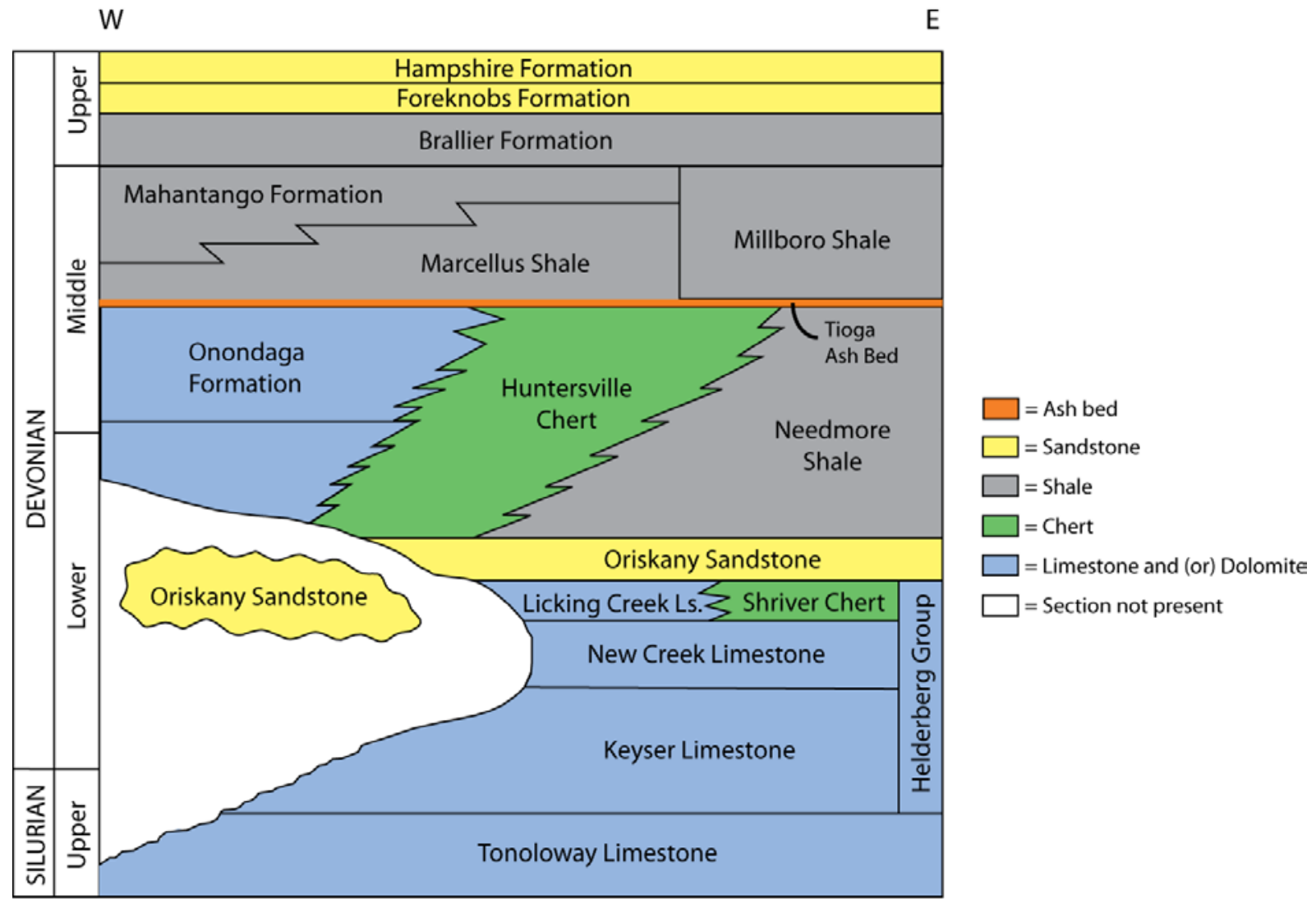

Figure 1. Schematic chart showing Upper Silurian to Upper Devonian strata in the central Appalachian basin (modified from Kulander and Dean, 1986; Flaherty, 1996; Milici and Swezey, 2006). 


\section{Structure}

Publications from mapping in the Williamsville 7.5-minute quadrangle (Haynes and Whitmeyer, 2010) and in the Staunton 30 x 60 minute quadrangle (Rader and Wilkes, 2001) show second-order anticlinal and synclinal structures encompassing the area of the field trip. These studies build on previous work that has documented prevalent third-order folds and faults (for example, Kulander and Dean, 1986; figs. 2, 3) in the Marcellus Shale. Third-order features are evident in outcrop but are not mappable at the 7.5-minute quadrangle scale, except as zones of deformation.

The Warm Springs anticline (Kulander and Dean, 1986; fig. 3), also named the Bolar anticline (Rader and Wilkes, 2001, p. 6), is cored with Silurian and Ordovician sandstones and carbonates that form the resistant Jack Mountain west of McDowell, Va. The McClung syncline (Butts, 1940) is underlain by Mississippian sandstones and Upper Devonian siltstones and sandstones that are resistant to weathering and form Shenandoah Mountain on the east side of the field trip area. Between these two prominent northeast-trending folds are several third-order folds that range from sub-meter to several meters in scale (fig. 3). These small-scale folds typically occur in the tightly compressed axes of second-order synclines that are cored by the structurally weak Millboro/Marcellus Shale. Excellent exposures of these third-order deformation features will be examined during this field trip.

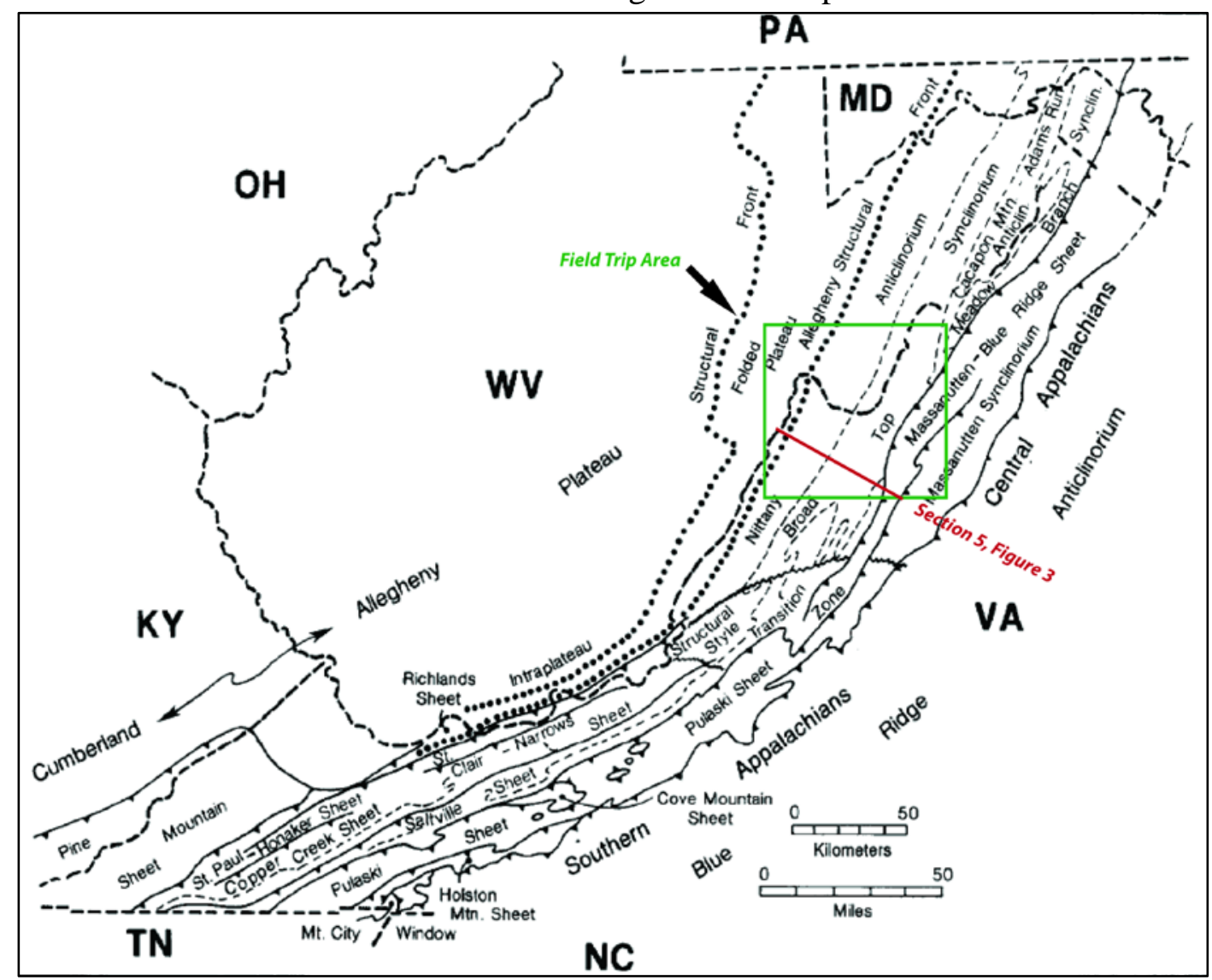

Figure 2. Regional structure map showing major tectonic regions, field trip area, and location of cross section in figure 3 (modified from Kulander and Dean, 1986); reprinted by permission of the AAPG, whose permission is required for further use). 


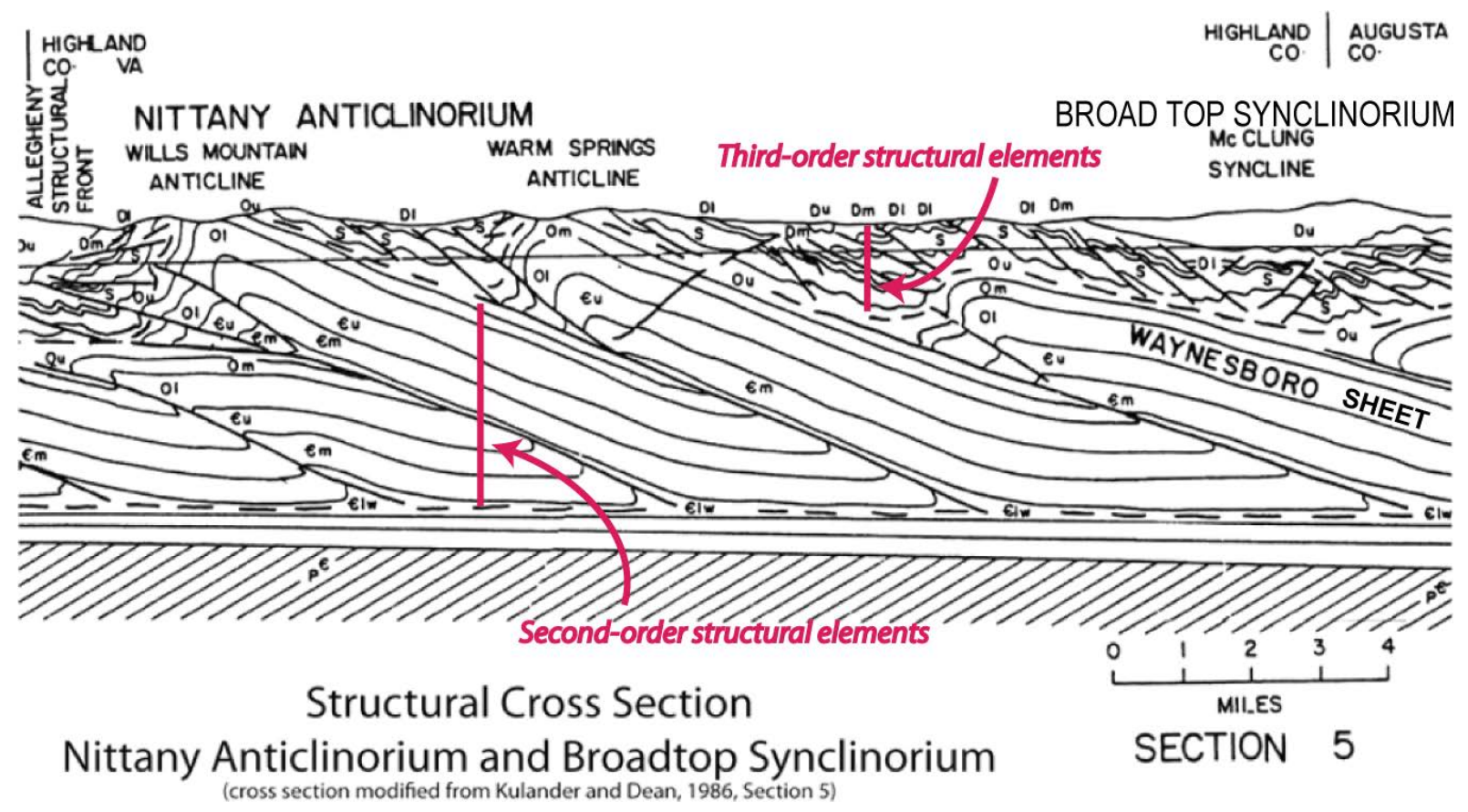

Figure 3. Cross section illustrating third-order structural elements within the middle and upper Paleozoic formations. €lw = Lower Cambrian Waynesboro Formation; $€ \mathrm{~m}=$ Middle Cambrian; $€ \mathrm{U}=\mathrm{Upper}$ Cambrian; OI = Lower Ordovician; Om = Middle Ordovician; Ou = Upper Ordovician; S = Silurian; DI = Lower Devonian; Dm = Middle Devonian; Du = Upper Devonian (modified from Kulander and Dean, 1986); reprinted by permission of the AAPG, whose permission is required for further use).

\section{Description of Individual Stops}

\section{Cowpasture River Valley}

Figures 4 and 5 show the geologic map of the Bullpasture Mountain area (Haynes and Whitmeyer, 2010) overlain on an oblique view of the area (looking northeast) from Google Earth. The locations of selected exposures in the valleys of the Cowpasture and Bullpasture Rivers that will be visited are shown. Results of the total organic carbon and vitrinite reflectance analyses for Marcellus Shale samples taken in the area are shown in figures 6 and 7.

Along the Cowpasture River south of Patna, a small unincorporated community in Highland County, Va., the riverbed is dry for much of the late spring, summer, fall, and even early winter months each year, as the entire flow of the river is lost to underground karst drainage pathways in the limestones of the Helderberg Group via several sink points. Once the river sinks in its bed, about 10 kilometers $(\mathrm{km})$ of riverbed are dry or nearly so, and several exposures of the Oriskany Sandstone, Needmore Shale, and Marcellus Shale become accessible. These allow for more detailed study of the stratigraphic and structural aspects of these units. 


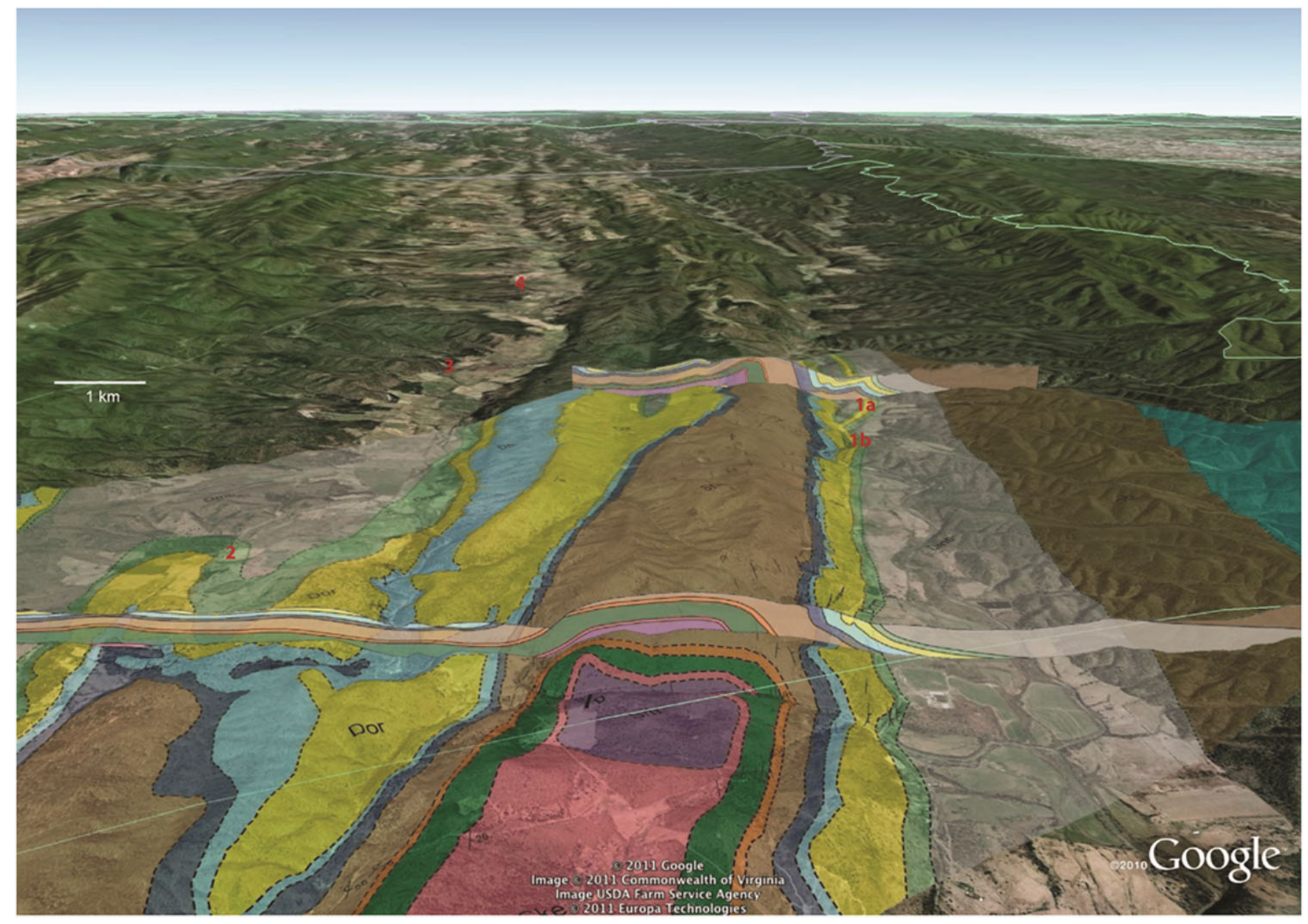

Figure 4. Geologic map of part of the Williamsville 7.5-minute quadrangle (Haynes and Whitmeyer, 2010) draped over Google Earth imagery (dated January 31,2007 ) and digital elevation model (DEM). Vertical cross sections of subsurface geology are superimposed on the ground surface. The oblique view looks northeast along the crest of Bullpasture Mountain, a structurally complex anticlinorium capped on the east by exposures of Tonoloway Limestone (brown) and on the west by Oriskany Sandstone (yellow) and Helderberg Group limestones (light blue). Field trip stops in this area (red text) are in the valleys of the Cowpasture River (stops 1a-1b, right) and the Bullpasture River (stops 2-4, left). The scale bar is accurate for the middle region of the image but inaccurate if extrapolated to the upper or lower regions of the image due to the oblique view. 


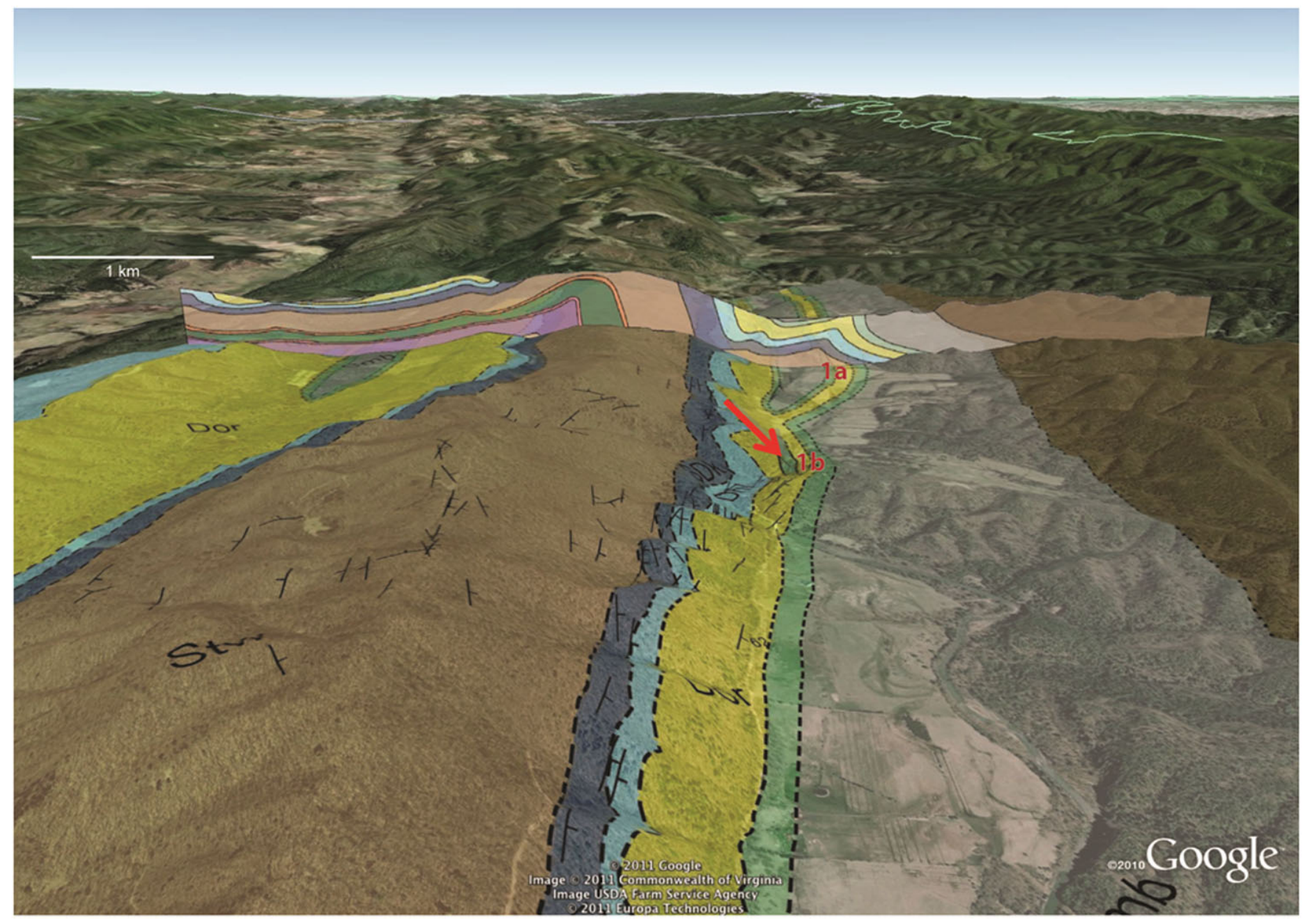

Figure 5. Closer view of the Cowpasture River and the area around stops $1 \mathrm{a}$ and $1 \mathrm{~b}$ in figure 4 . Note the infolded Needmore Shale (arrow) immediately north of the meander at Laurel Gap in a very tight syncline in the Oriskany Sandstone. Base imagery and digital elevation model (DEM) from Google Earth (dated January 31, 2007). The scale bar is accurate for the middle region of the image but inaccurate if extrapolated to the upper or lower regions of the image due to the oblique view. Stw = Silurian Tonoloway Limestone (light brown); Dk = Silurian-Devonian Keyser Limestone (dark blue); Dhl = Devonian Helderberg Group (light blue); Dor = Devonian Oriskany Sandstone (yellow); Dnm = Devonian Needmore Shale (green); Dmb = Devonian Millboro Shale (gray); $\mathrm{Db}=$ Brallier Formation (brown). 


\section{Stops 1 - 4: Total Organic Carbon, weight \%}
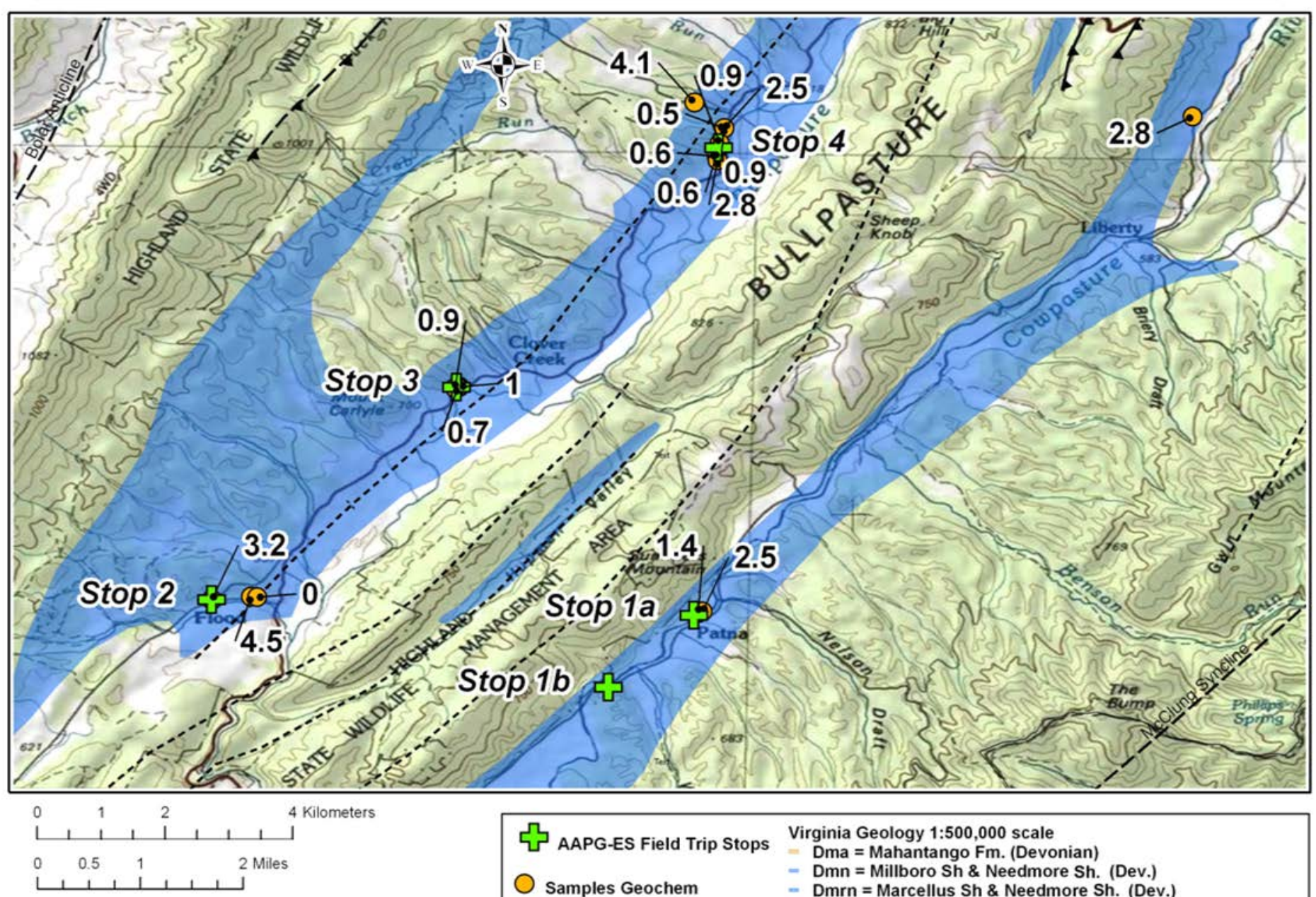

TOC = ' 0 ' means value is not available

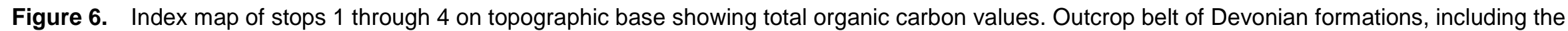
Mahantango, Marcellus, Millboro, Needmore, and Huntersville Chert, is shown in blue, from 1:500,000-scale digital geologic map. Total organic carbon values (weight percent) posted next to sample locations (geologic map modified from Dicken and others, 2005). 


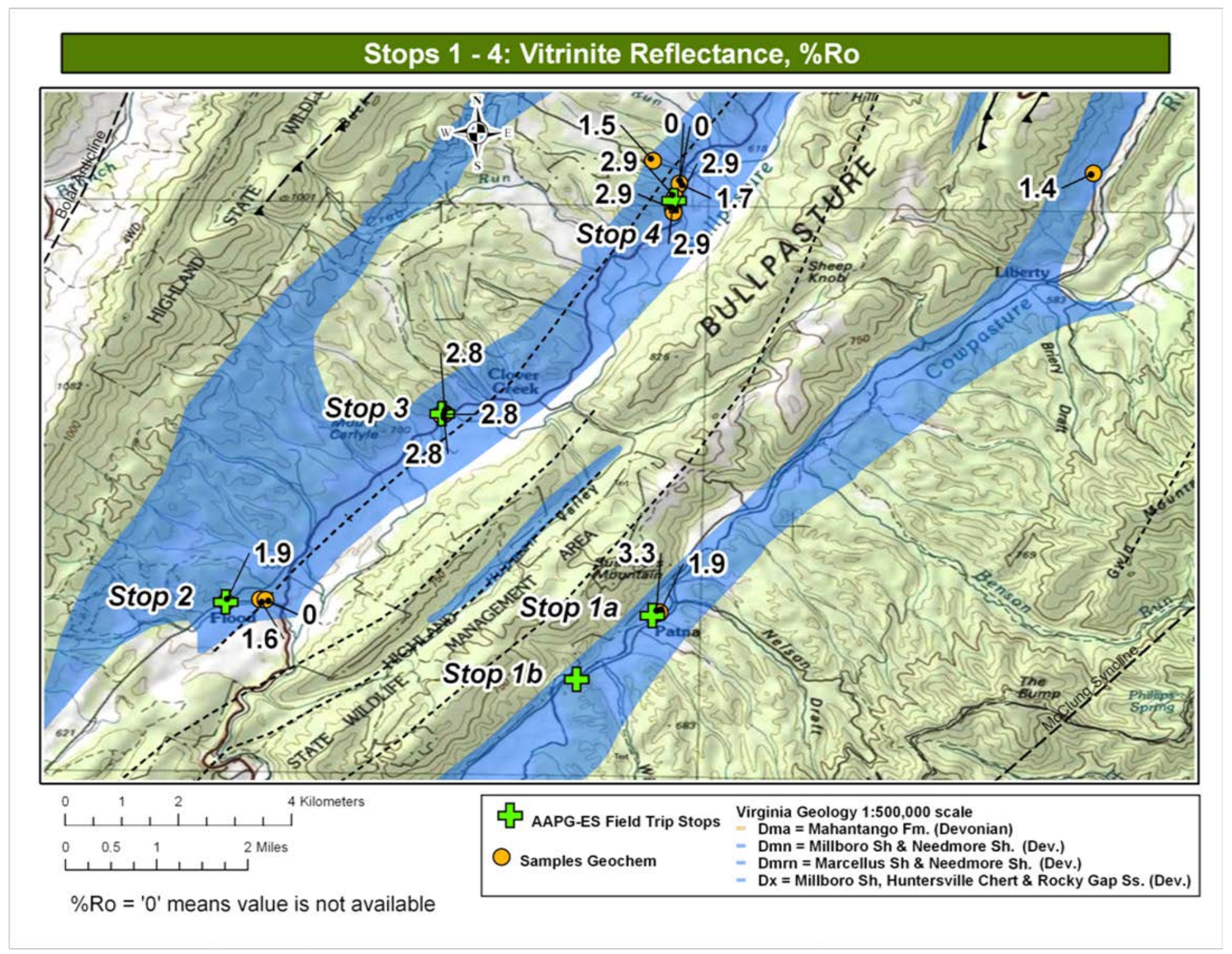

Figure 7. Index map of stops 1 through 4 on topographic base showing vitrinite reflectance values. Outcrop belt of Devonian formations, including the Mahantango, Marcellus, Millboro, Needmore, and Huntersville Chert, is shown in blue, from 1:500,000-scale digital geologic map (modified from Dicken and others, 2005). Vitrinite reflectance values (\%Ro) posted next to sample locations. 
Stop 1a: Seasonally dry riverbed $2 \mathrm{~km}$ north of Laurel Gap (exposures extend from N. $38.238317^{\circ}, \mathrm{W} .79 .518517^{\circ}$ at the north end to $\mathrm{N} .38 .235833^{\circ}, \mathrm{W} .79 .521333^{\circ}$ at the south end)

At this location, which is where the Forest Service road in Nelson Draft tees into S.R. 614 about $2 \mathrm{~km}$ north of the church in Laurel Gap, the contact of the Needmore and Marcellus is exposed in a dry riverbed along an open meander of the Cowpasture River (figs. 8-15). The geometry of this meander allows for study of two exposures of the same stratigraphic interval, along strike with each other (fig. 9). Here the upper beds of the Needmore are calcareous mudrocks with some whole and fragmental fossils, dipping gently to the northwest (figs. 10, 11). Overlying them are a few meters of black fissile shale that abruptly change from uniformly bedded mudrocks into a highly folded and faulted interval that includes variably oriented calcareous concretions and broken and fractured calcareous layers of various sizes (figs. 12, 13). This interval can be traced in outcrop for several tens of meters to where fluvial gravels bury the outcrop. Beginning at the outside of the meander (by the barn along S.R. 614), the exposures one sees while looking upriver can be walked out from the uppermost Needmore and lowest Marcellus into the contorted zone (fig. 12), which then extends farther upriver well past the point where the stream in Nelson Draft joins the Cowpasture River. Northwest-dipping beds of Oriskany Sandstone are visible on the east side of S.R. 614 at the junction with Nelson Draft road. Downriver, the exposures in the meander can be walked out to the limit of riverbed outcrops, which are several tens of meters downriver beyond the cement weir (a private driveway), where the contorted zone again is completely buried by river gravels.

Prominent deformation features in this interval include meter-scale fault and shear zones, centimeter- to decimeter-scale plunging anticlines and synclines, and prevalent fractures (figs. 13-15). Several small-scale folds and faults are oblique to the northeast structural grain and may have resulted from semi-chaotic, localized adjustments to diminished space along the larger scale synclinal axis of the riverbed. Principal joint sets, which possibly predate compaction and lithification, as shown by their relation to some of the calcareous nodules (fig. 15), predominantly show a northwest strike in both folded (fig. 16) and unfolded (fig. 17) zones, with some joint sets overprinted and obscured within the most highly deformed regions. The strike of the principal joint sets is roughly parallel to the direction of regional compression during the Alleghanian Orogeny, which suggests that most of the joint sets, and presumably the small-scale folding and faulting, are related to this event. 


\section{Cowpasture River dry exposures}
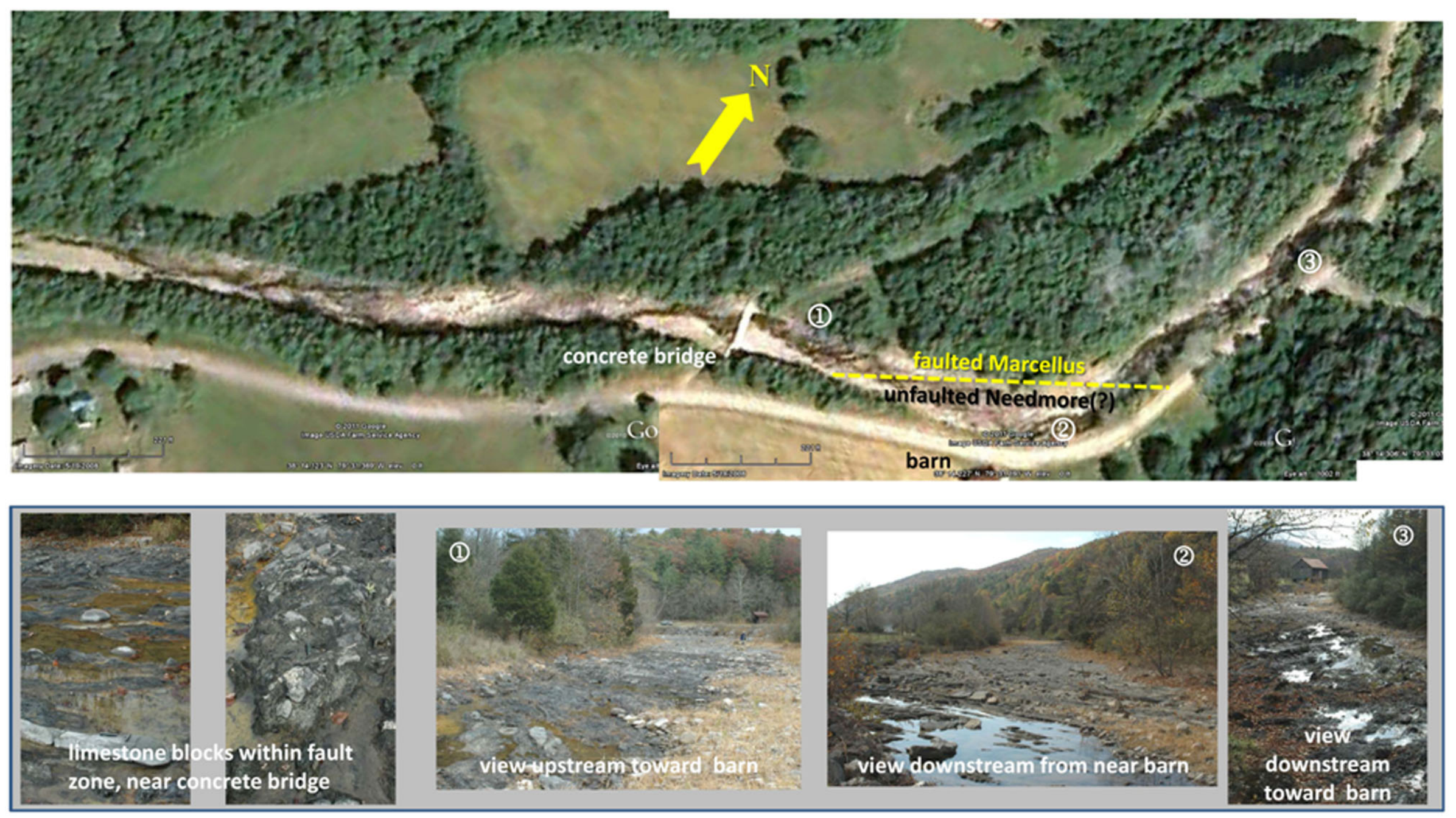

Figure 8. Stop 1a, along and in the Cowpasture River. Base imagery from Google Earth (image date May 19, 2008, USDA Farm Service Agency, @2011 Google). 


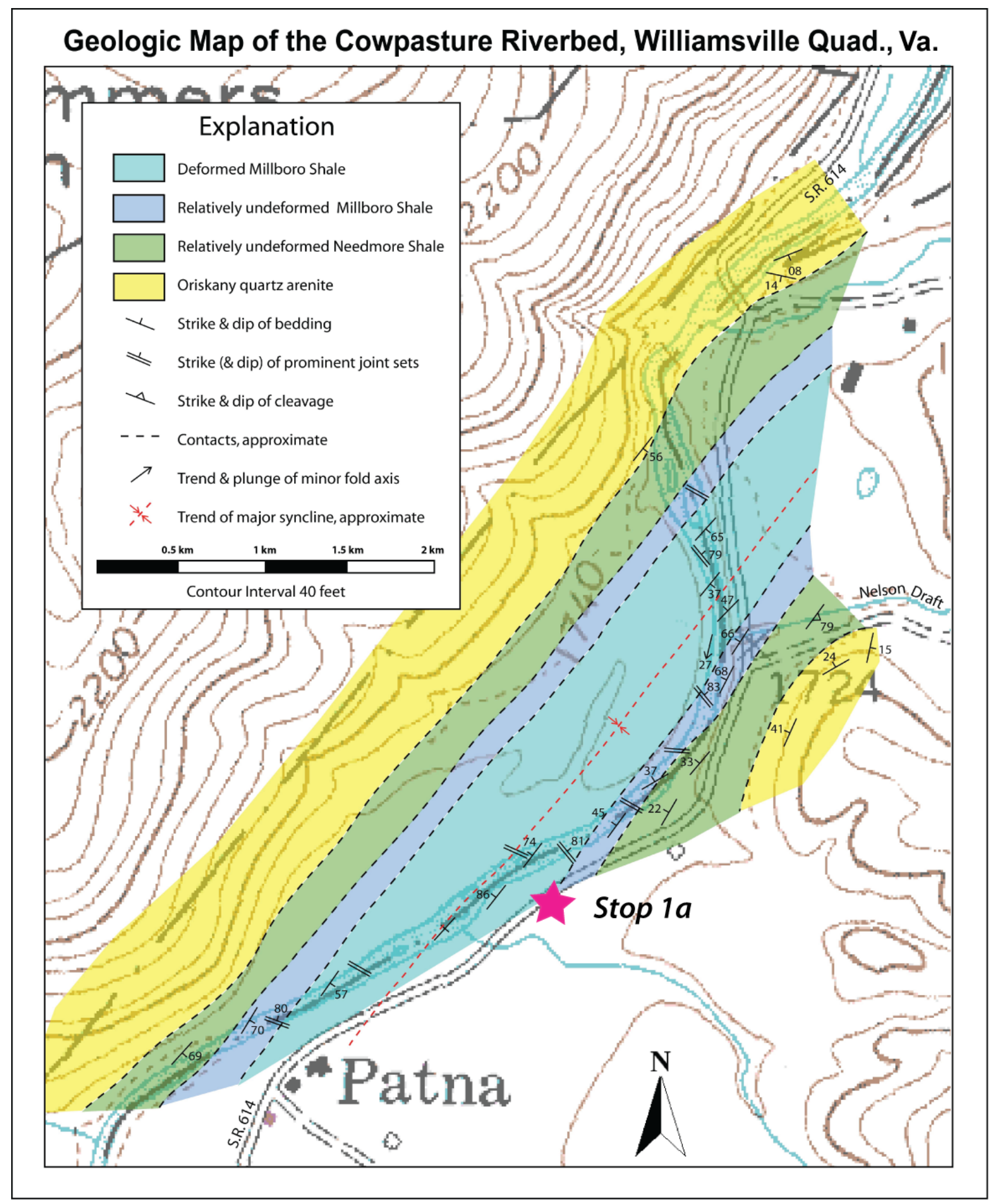

Figure 9. Geologic map of the Cowpasture riverbed, Stop 1a, near Patna, Va. (Caro and others, 2010). 


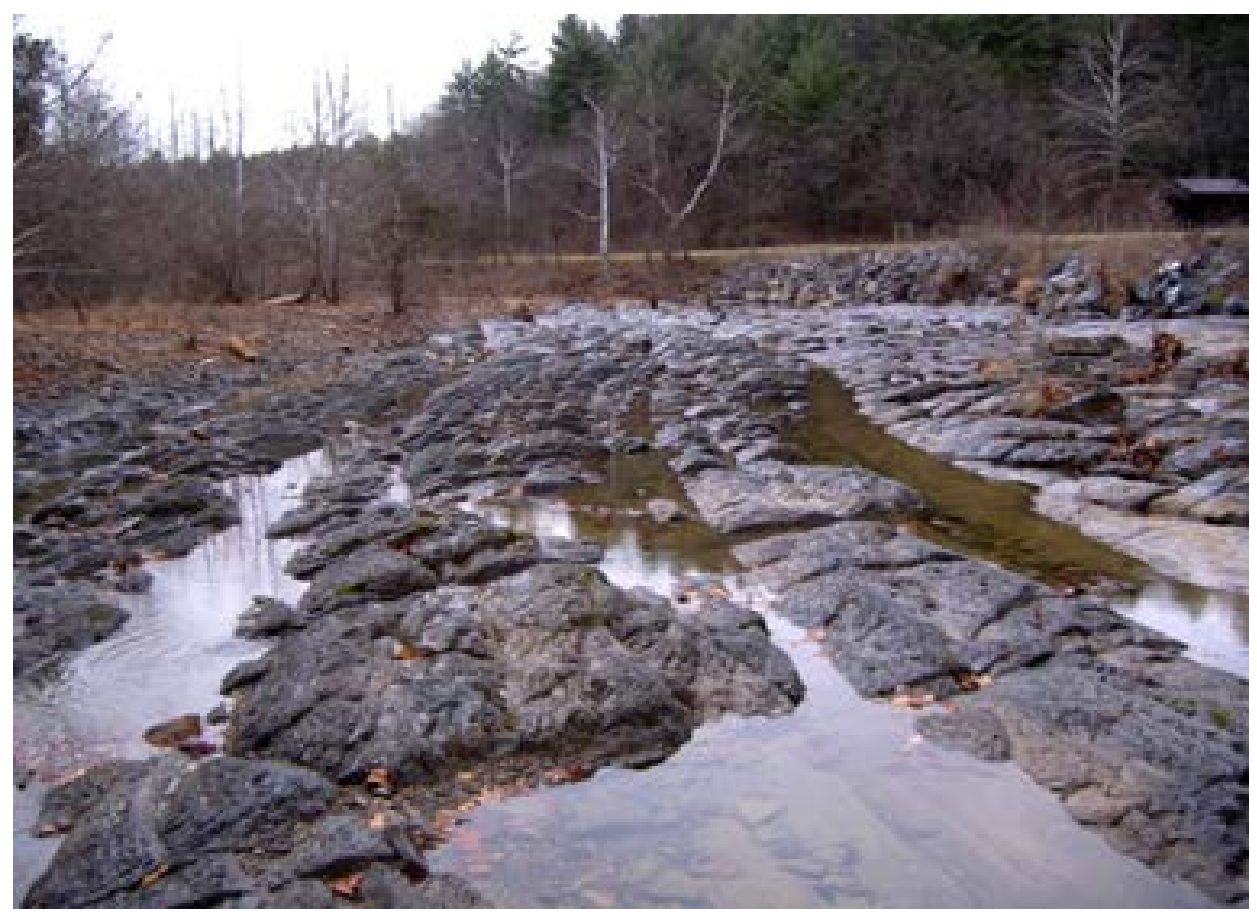

Figure 10. Ledges of northwest-dipping and fractured Needmore Shale at stop 1a. There are several calcareous layers, some of which are moderately fossiliferous and include whole and fragmental Phacops. Photo: John Haynes.

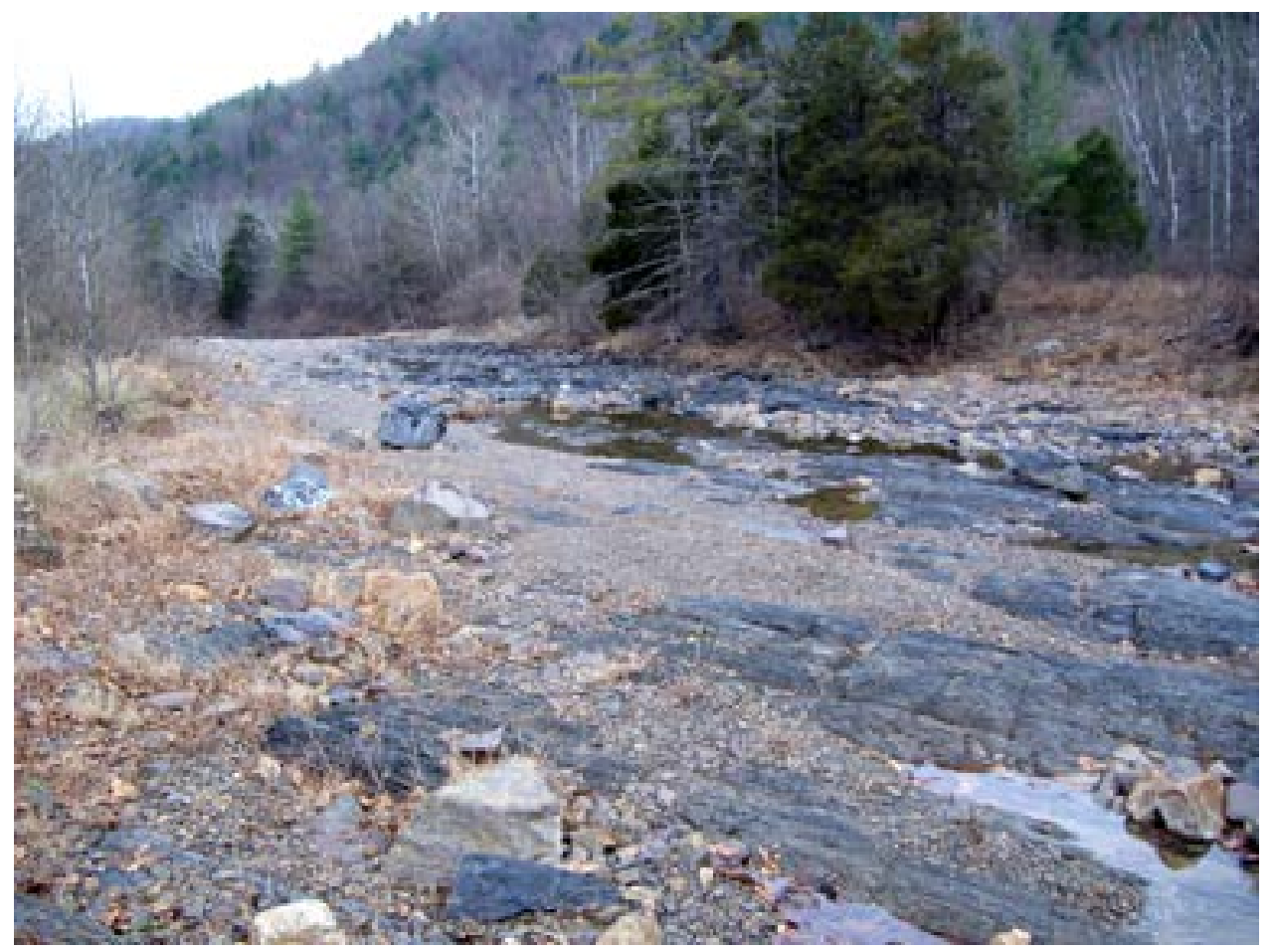

Figure 11. Ledges of Needmore Shale (foreground) and Millboro Shale (by conifer trees) at stop 1a upriver from the concrete weir (upper left-center). The contact between the two units is at top-center, but its precise location is problematic due to a structural transition from gently dipping but otherwise structurally uncomplicated beds to beds with extensive small-scale folds and faults. Photo: John Haynes. 


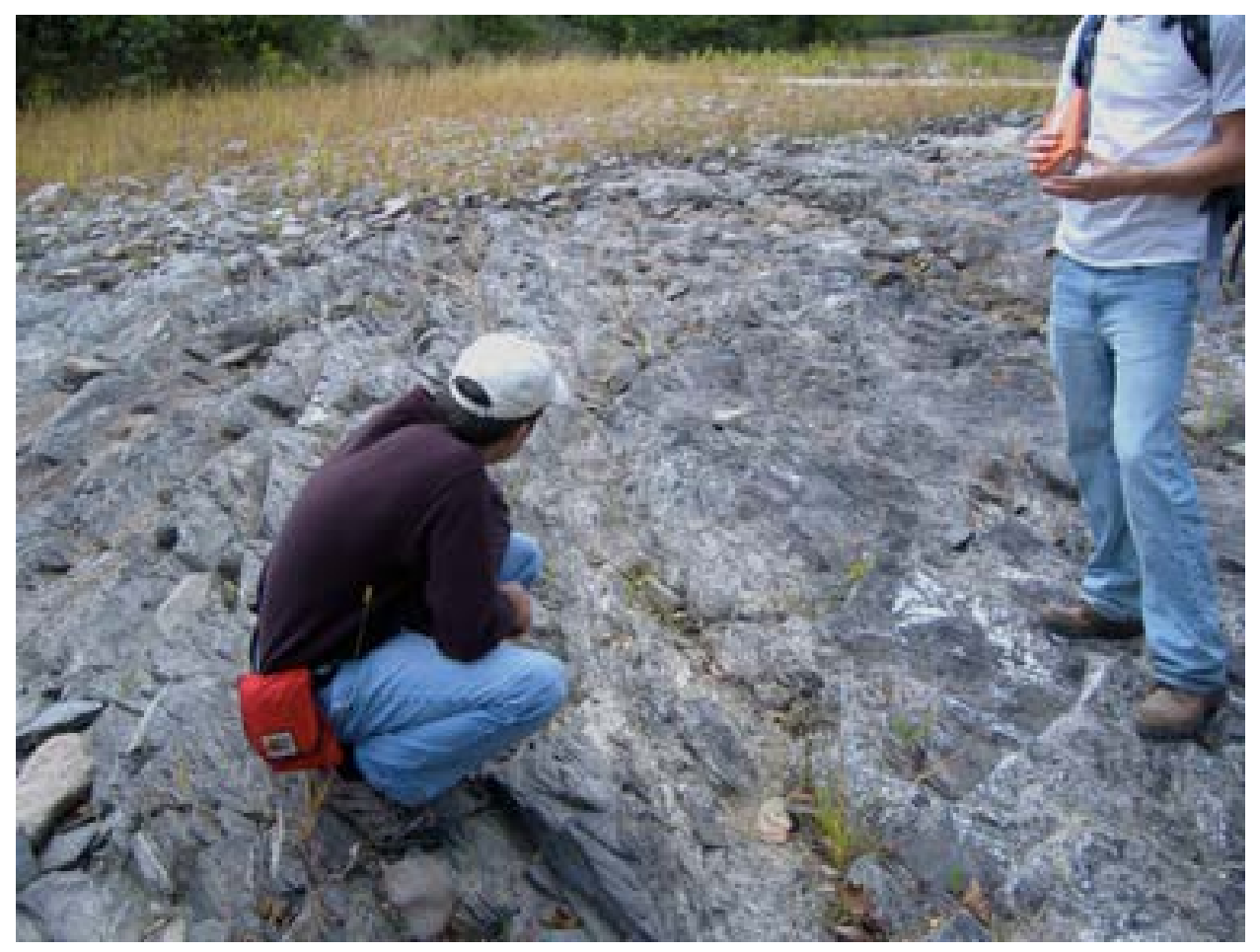

Figure 12. Steven Whitmeyer and James Madison University student Seldon Walker at stop 1a, on either side of the contact between relatively undeformed Needmore Shale (left) and highly deformed Needmore and Marcellus Shale (right). Photo: John Haynes.

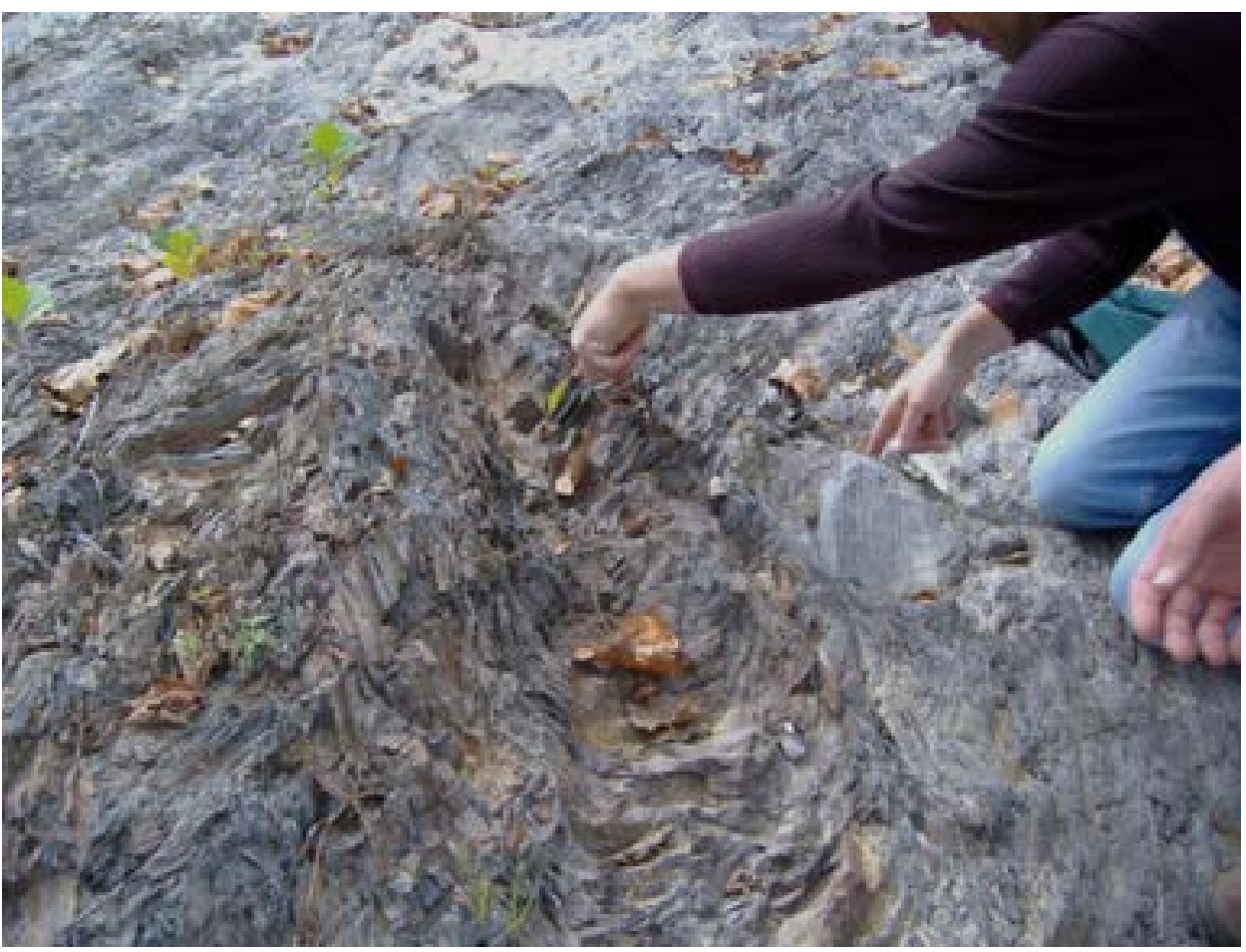

Figure 13. Shale with extensive small-scale folding throughout, which contrasts with a calcareous nodule that exhibits planar lamination within it that has not been affected by folding. Photo is a closeup of the zone of highly deformed Marcellus Shale shown in figure 12. Photo: John Haynes. 


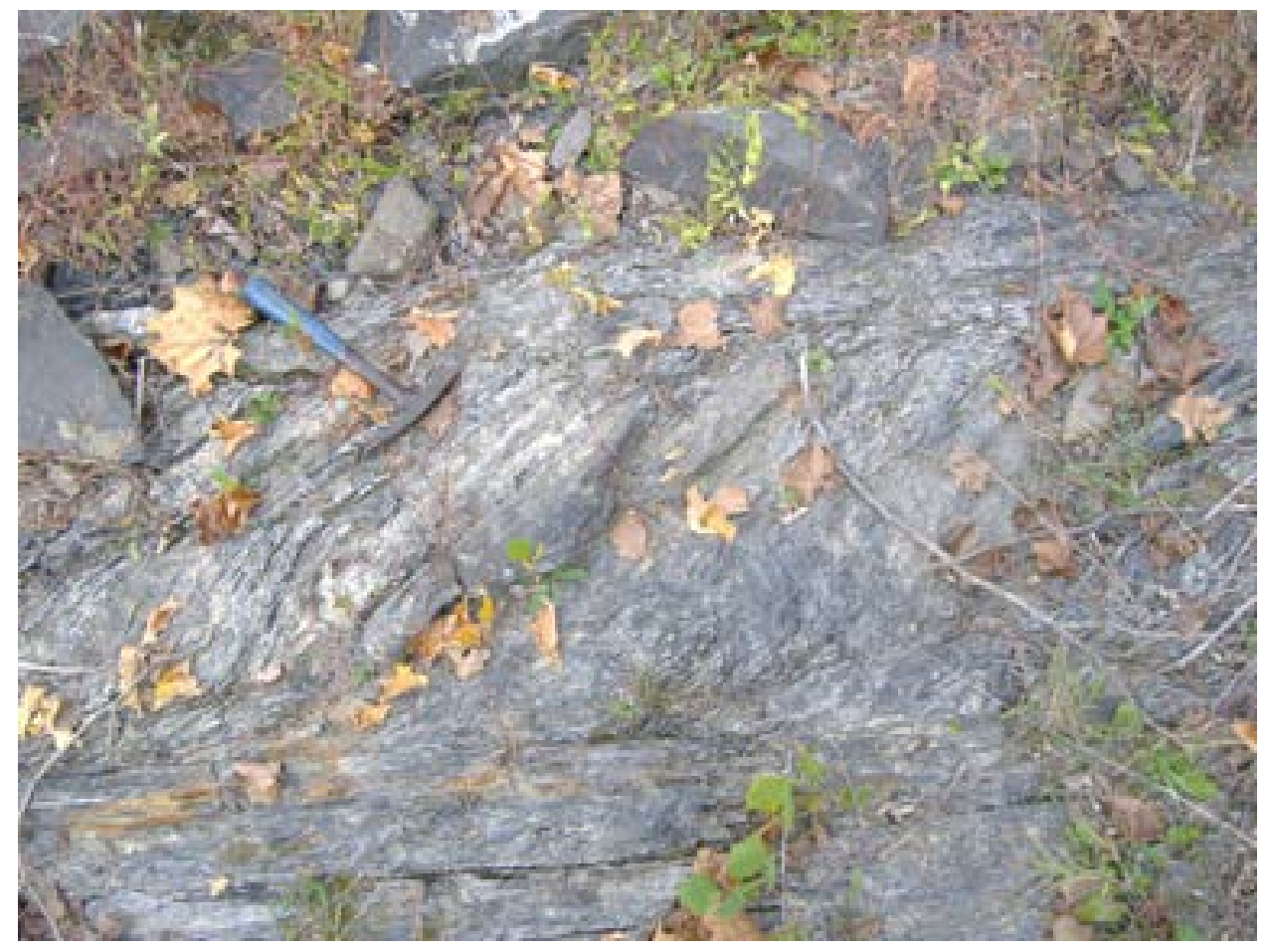

Figure 14. A small shear zone with duplex-like geometry but with apparent strike-slip rather than dip-slip movement from the zone of highly deformed Marcellus Shale north of the meander at stop 1a. Note hammer for scale. Photo: John Haynes.

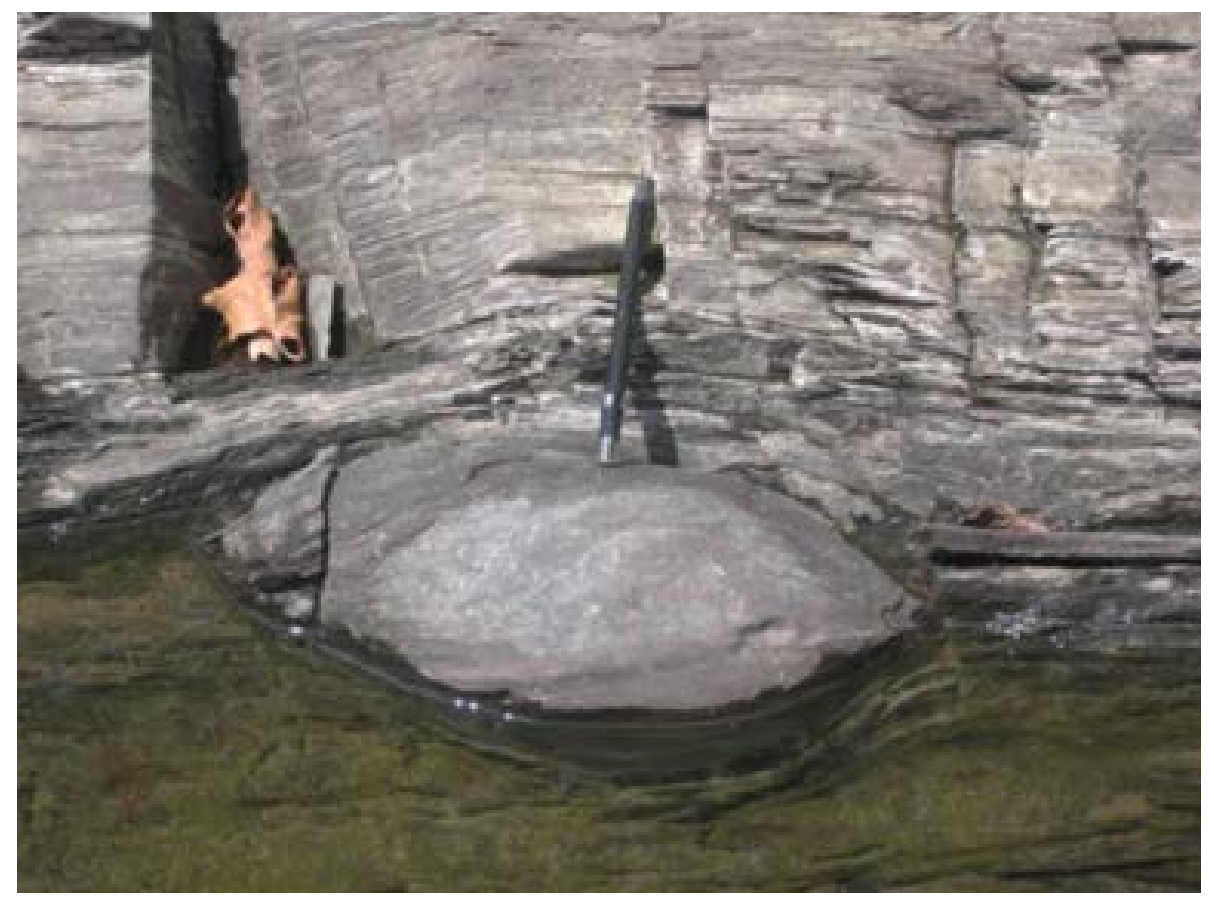

Figure 15. Fractures in the Needmore Shale in the riverbed of the Cowpasture River at stop 1a that, because of the fanning of those fractures around the curvature of the nodule or concretion, likely predate the growth of the nodule, and (or) the compaction of the mud (now shale) around the nodule. Note mechanical pencil for scale. Photo: Steven Whitmeyer. 


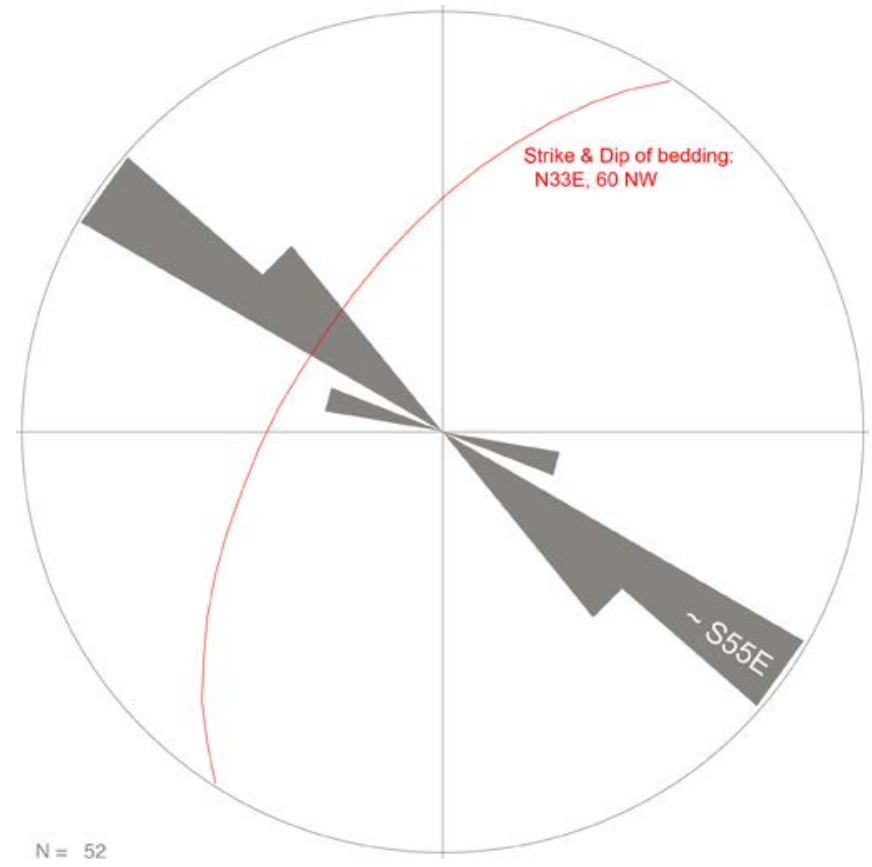

Figure 16. Rose diagram of joint sets in the deformed zone of the lower Millboro Shale in the bed of the Cowpasture River in the vicinity of stop 1a. Note dominant joint set striking S.55 E. Great circle in red shows strike and dip of bedding in the riverbed at N. $33^{\circ} \mathrm{E} ., 60^{\circ} \mathrm{NW}$.

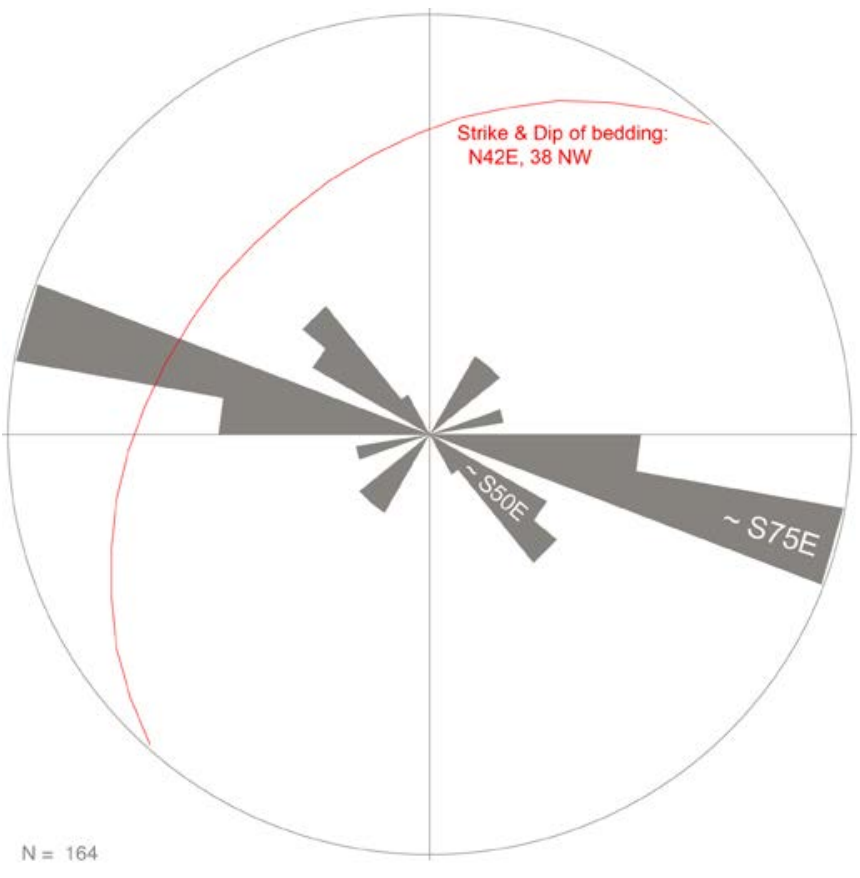

Figure 17. Rose diagram of joint sets in the upper several meters of the Needmore Shale in the bed of the Cowpasture River at stop 1a, where that interval is essentially undeformed. Note the presence of the S. $50^{\circ} \mathrm{E} .-\mathrm{S} .55^{\circ} \mathrm{E}$.-striking joint sets that dominate the rose diagram in figure 16 but are subordinate to the S. $75^{\circ}$ E.-striking joint set in this diagram. Great circle in red shows strike and dip of bedding in the riverbed at N. $42^{\circ} \mathrm{E} ., 38^{\circ} \mathrm{NW}$., similar to the orientation of bedding in figure 16 except for a shallower dip angle. 


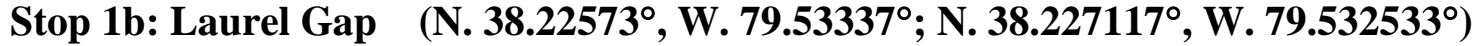

About 500 m northeast of the church in Laurel Gap is a tight synclinal kink fold in the Oriskany Sandstone (fig. 18) that is visible from S.R. 614 as one looks south-southwest into the river gap. These folds have recently (winter 2010-11) been made more visible by logging and land clearing on the ridges immediately east and northeast of the church. In the new roadcut east of S.R. 614, one can observe the Oriskany Sandstone and its contact with the overlying Needmore Shale (fig. 19). Within the Needmore Shale, there are at least three ash beds, including two that are gray and one that is orange (fig. 20). Above the third ash bed, there is dark-gray to black shale with chaotic bedding that may be the Marcellus Shale. In the dry bed of the Cowpasture River parallel to S.R. 614, the synclinal kink fold contains a deformed mass of Needmore Shale along its axis, and on the northwest limb there is also an exposure of the cherty sandstone at the very top of the near-vertical ledge of Oriskany Sandstone; it is possibly Huntersville Chert facies that was deposited on the Oriskany.

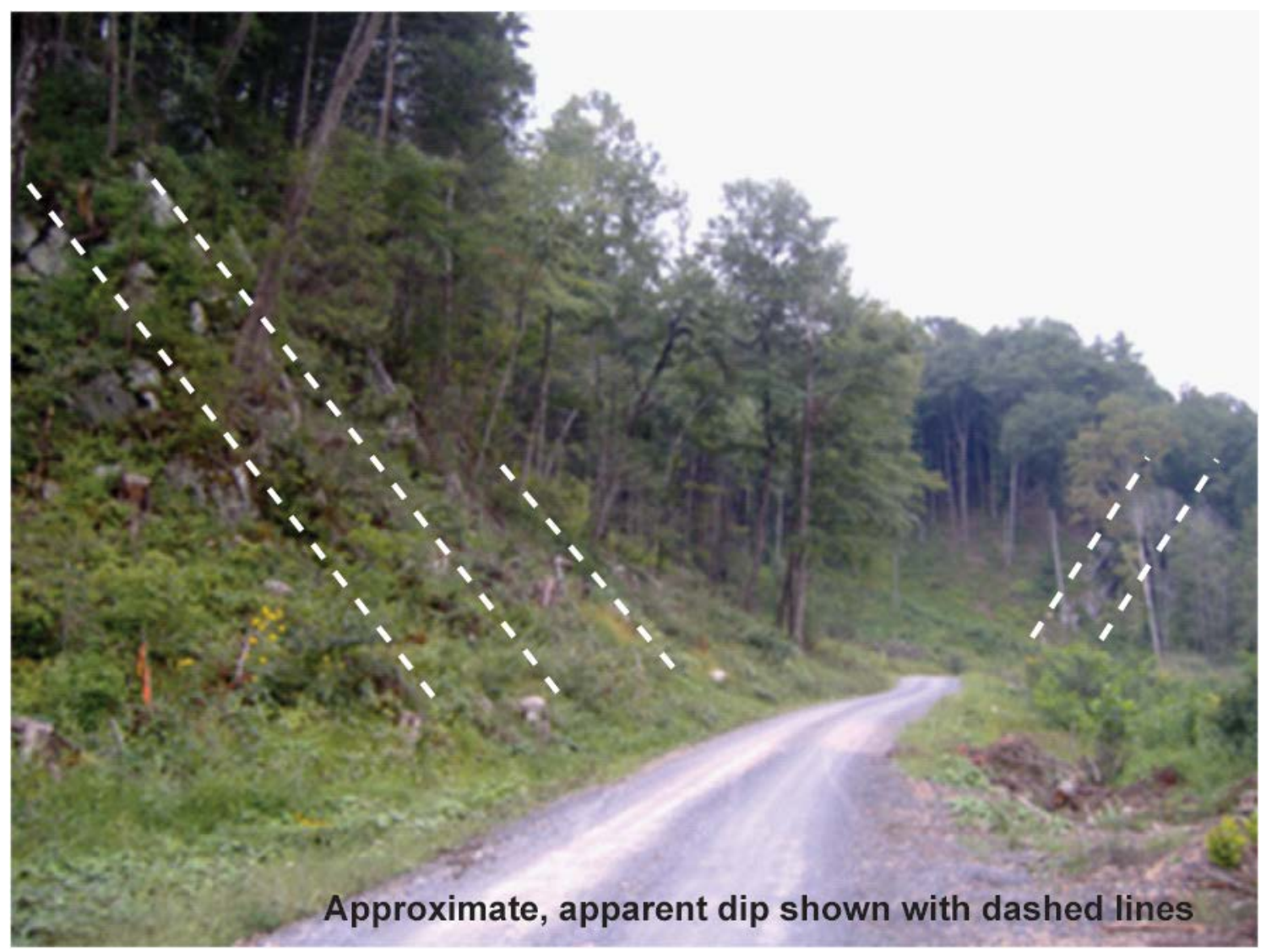

Figure 18. View to the southwest of kink-folded Oriskany Sandstone at stop $1 b$. The ledges at left in the foreground dip to the northwest, whereas the ledges in the background at right dip to the southeast. Photo: John Haynes; annotation: James Coleman. 


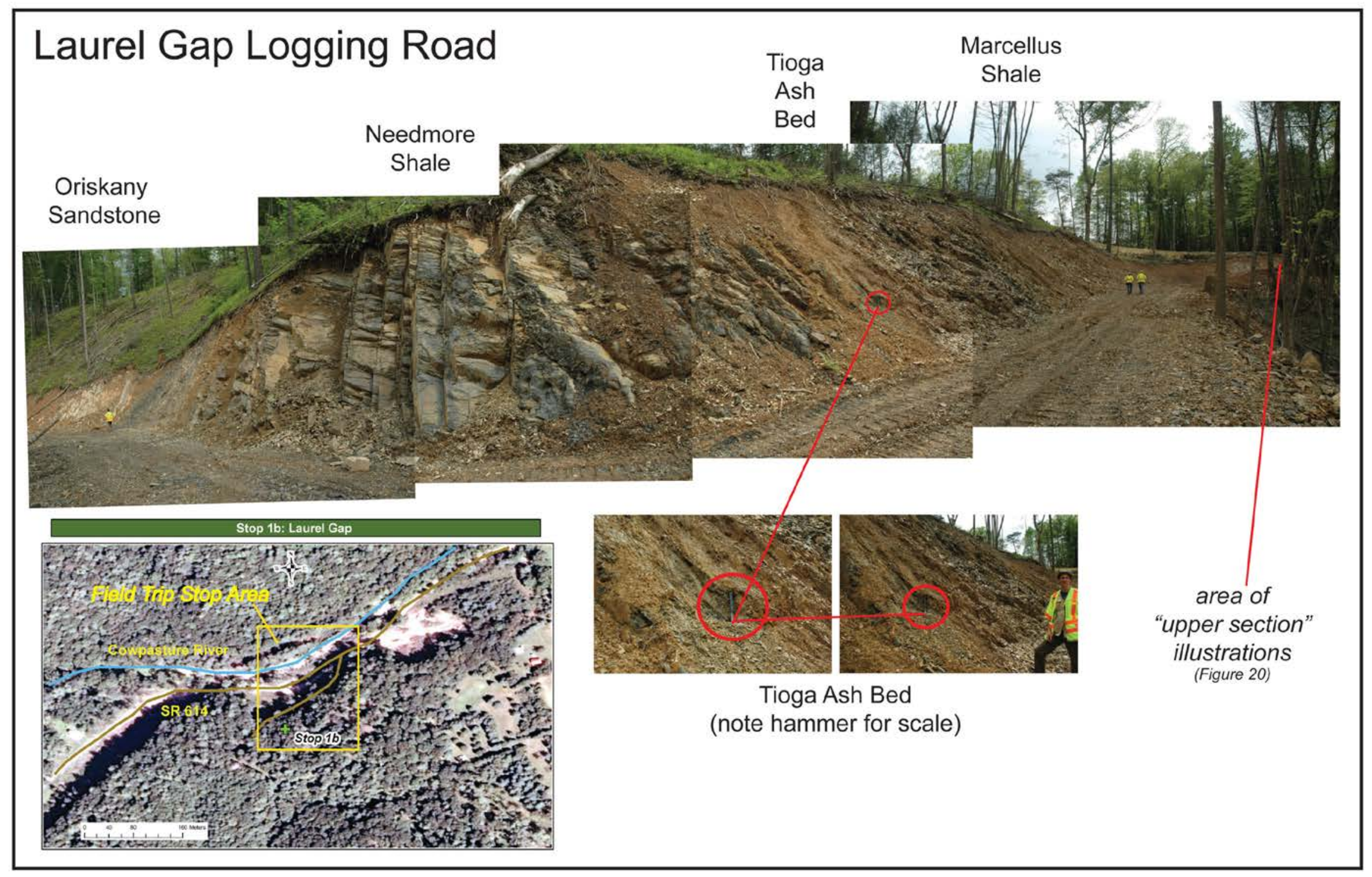

Figure 19. Laurel Gap roadcut at stop 1b, lower section. 


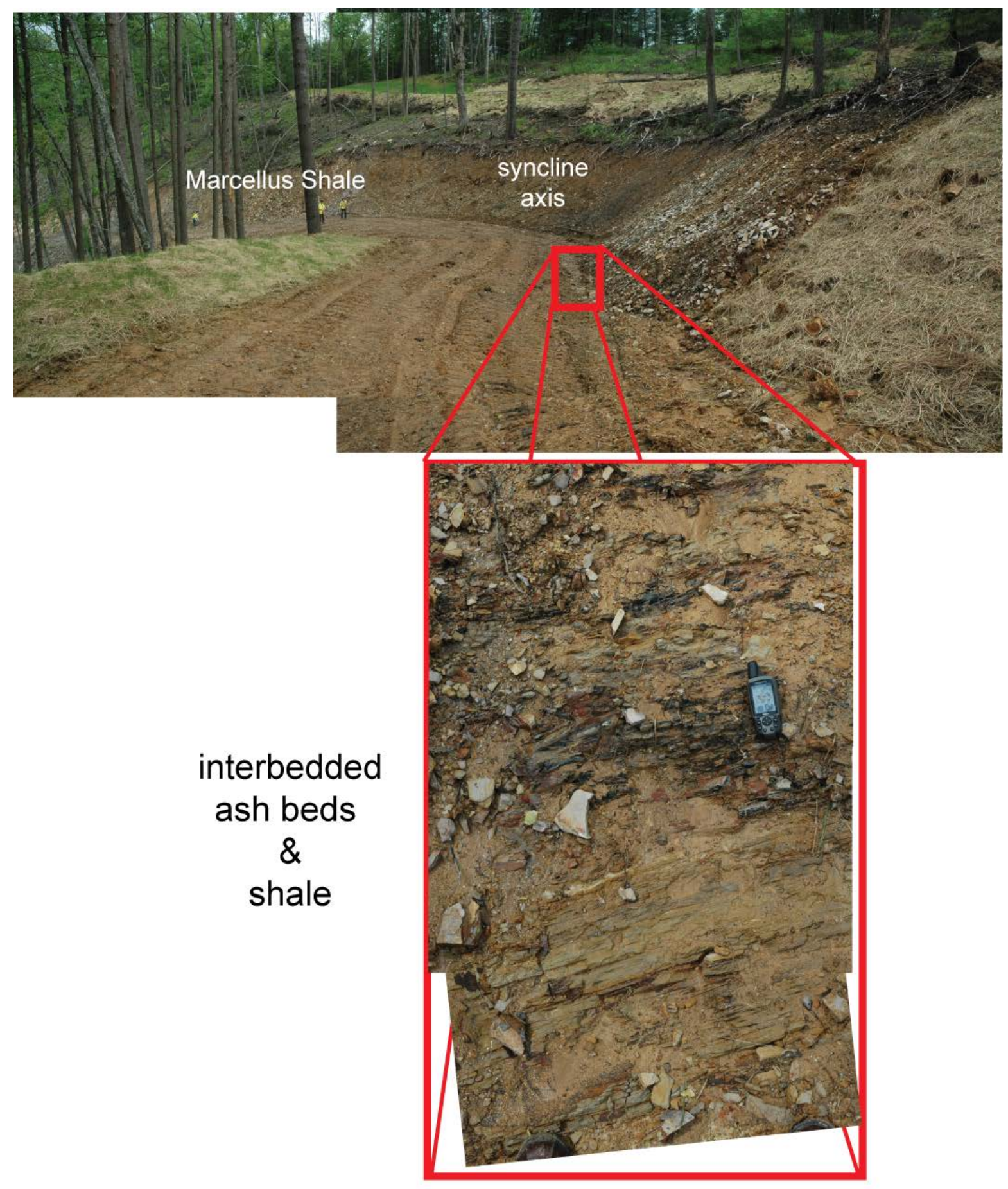

\section{Laurel Gap Logging Road - upper section}

Figure 20. Laurel Gap Logging Road (upper section), stop 1b, looking downhill and to the northeast. 


\section{Bullpasture River Valley}

\section{Stop 2: Settlement of Flood, Va., on S.R. 609 (N. 38.238017 , W. 79.589133) Strike N. $41^{\circ}$ E., Dip $32^{\circ}$ SE.}

Figure 21 shows the stop 2 area. Stratigraphically higher in section than stops $1 \mathrm{a}$ and $1 \mathrm{~b}$ and lower than stops 3 and 4, figure 22 shows the lowermost Marcellus is black, pyritic, fissile shale with limestone concretions. Third-order deformation is preserved differently in the shale than the limestone beds. The shales exhibit small-scale folds or intervals with shearing bounded by intervals with no shearing or folding. The limestones contain folded and faulted beds that indicate the limestone beds were consolidated when subjected to the stress that caused the deformation. This observation suggests that tectonic stress rather than synsedimentary deformation caused the disrupted bedding in this outcrop.

\section{Exposure of Millboro Shale near Flood, Va.}

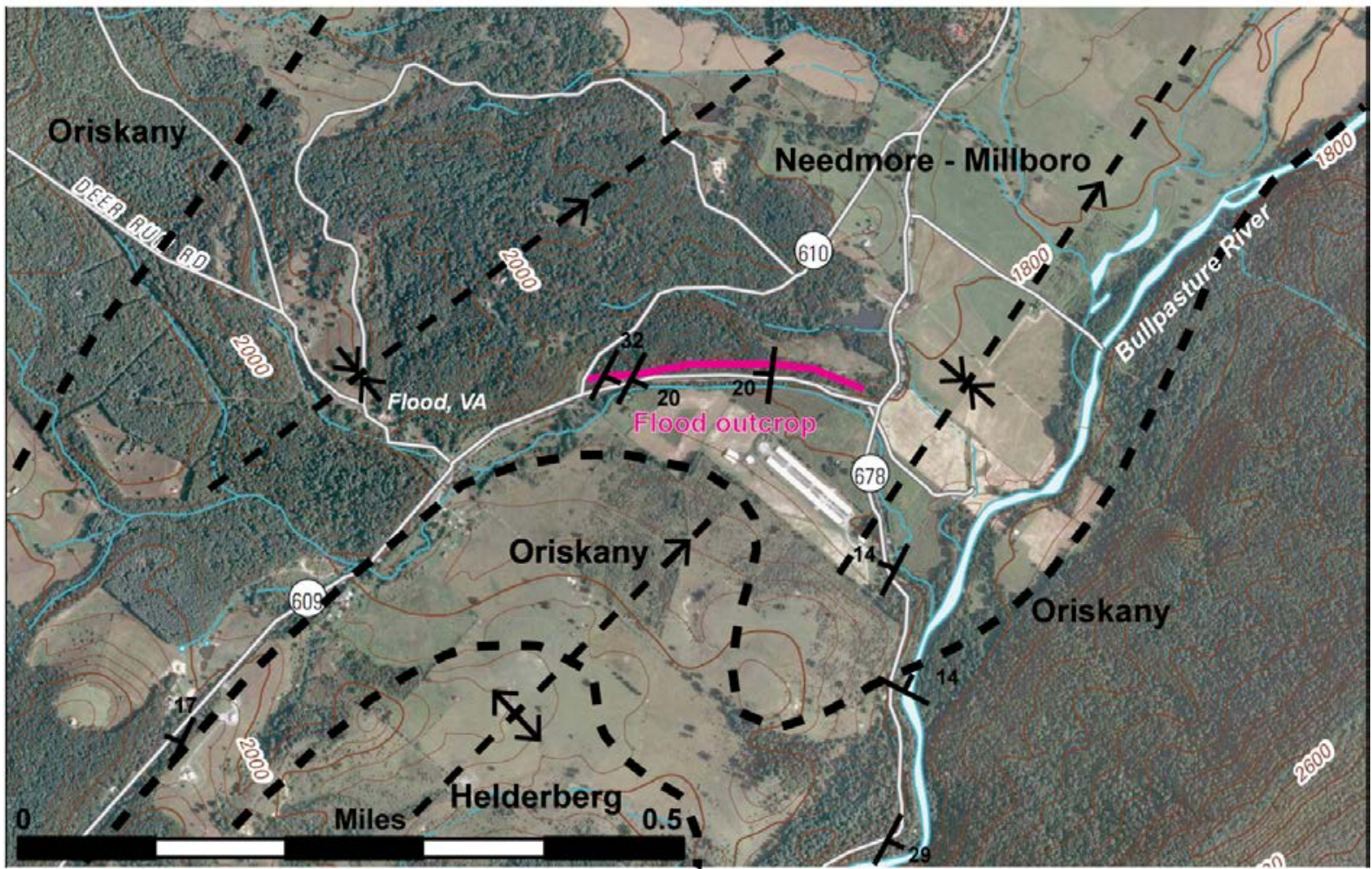

Figure 21. Sketch geologic map of stop 2 area showing Devonian Helderberg Group to Millboro Shale near Flood, Va. Base map is VA_Williamsville_20110510_TM_geo.pdf, available from the USGS Map Store (http://store.usgs.gov); geologic annotation from unpublished field maps of G.P. Wilkes, Virginia Department of Mines, Minerals and Energy (DMME), and J.L. Coleman and C.S. Swezey. 


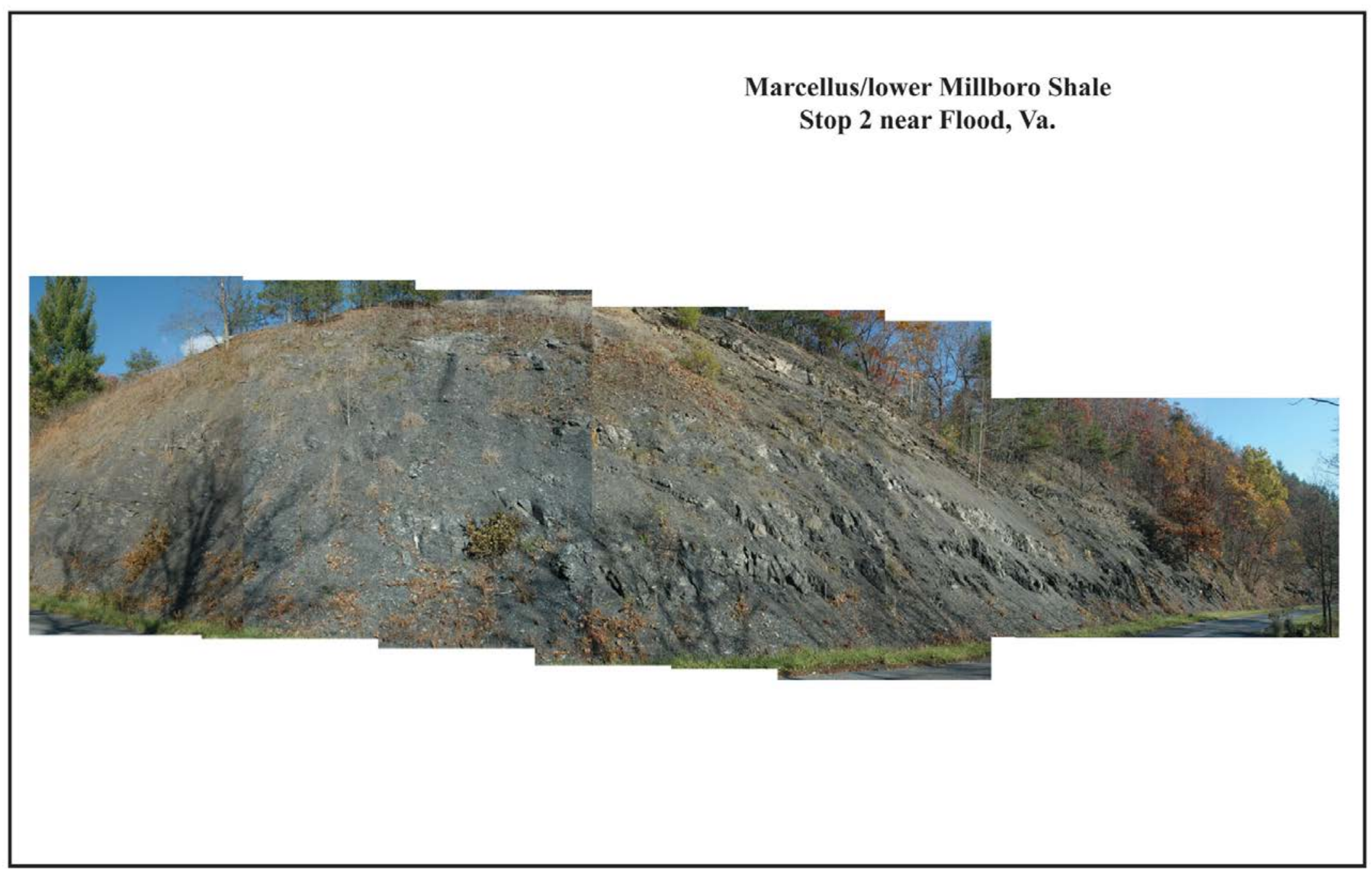

Figure 22. Photomontage at stop 2, looking north. This view of the north side of the roadcut illustrates the chaotic bedding of the

Marcellus/lower Millboro Shale. Calcareous-rich intervals have greater continuity than the less calcareous intervals. Overall structural dip is to the northeast, to the right end of the photomontage. 


\section{Stop 3: $1 \mathrm{~km}$ west-southwest of Clover Creek $\quad\left(\mathrm{N}^{3} 38.2678^{\circ}\right.$, W. $\left.79.55473^{\circ}\right)$}

On the west side of S.R. 678 about $1 \mathrm{~km}$ west-southwest of the old church at Clover Creek (fig. 23) is an exposure of nearly flat-lying Marcellus (Millboro) Shale that measures about $9 \mathrm{~m}$ high. This exposure is probably close to the axis center of the Bullpasture valley syncline, and, perhaps because of this there is little apparent folding of the strata. Multiple joint sets are exposed at this location (fig. 24), some of which parallel joint sets in the Cowpasture riverbed described earlier. In February 2011, Haynes and others generated a synthetic gamma ray log of this exposure using a hand-held scintillometer on loan to James Madison University from the Virginia Division of Geology and Mineral Resources (fig. 25). This revealed that the most radioactive zone, and presumably the most organic-rich zone as well, is located about two-thirds of the way up the exposure (fig. 26).

Numerous calcareous concretions weather out of the face of this exposure, and some of these have an internal septarian structure. Many of them also contain appreciable barite and authigenic euhedral quartz.

\section{Millboro Shale Outcrop at Clover Creek, Va.}

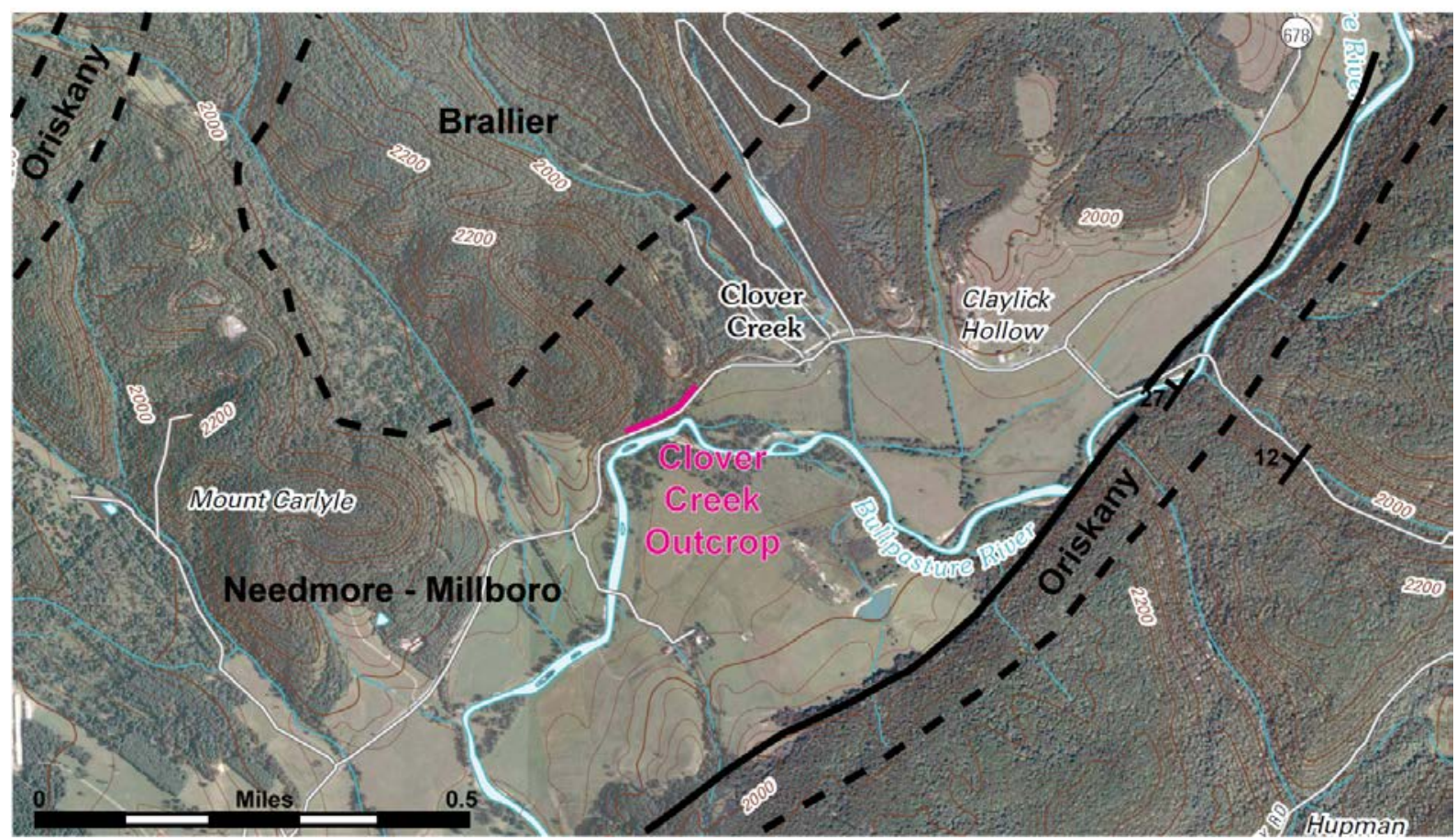

Figure 23. Sketch geologic map of stop 3 area showing Devonian Oriskany Sandstone to Brallier Formation near Clover Creek, Va., along the Bullpasture River; base map is VA_Monterey_SE_20110510_TM_geo.pdf, available from the USGS Map Store (http://store.usgs.gov); geologic annotation from unpublished field maps of G.P. Wilkes, DMME, and J.L. Coleman and C.S. Swezey. 


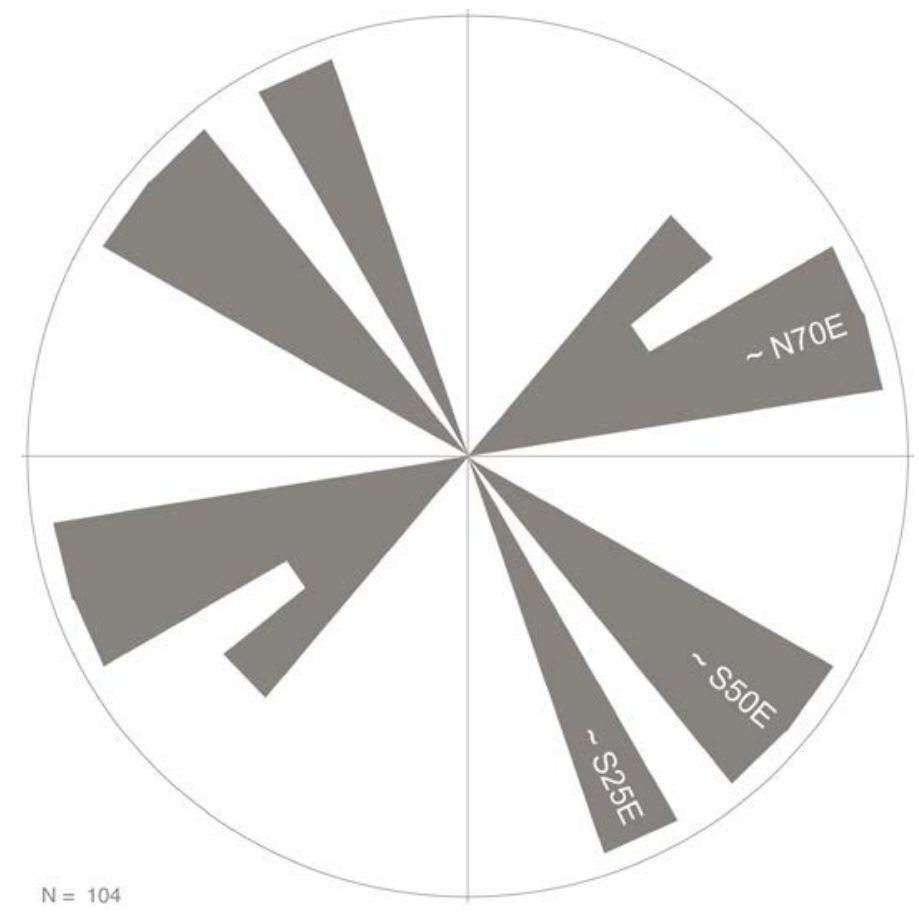

Figure 24. Rose diagram of joint sets in the shale along the Bullpasture River at stops 3 and 4 . The S. $50^{\circ}$ E.- striking joint set is also apparent in the Cowpasture River bed (figs. 16, 17) and thus may predate the complex deformation seen in the lower Millboro Shale in the Cowpasture River bed.

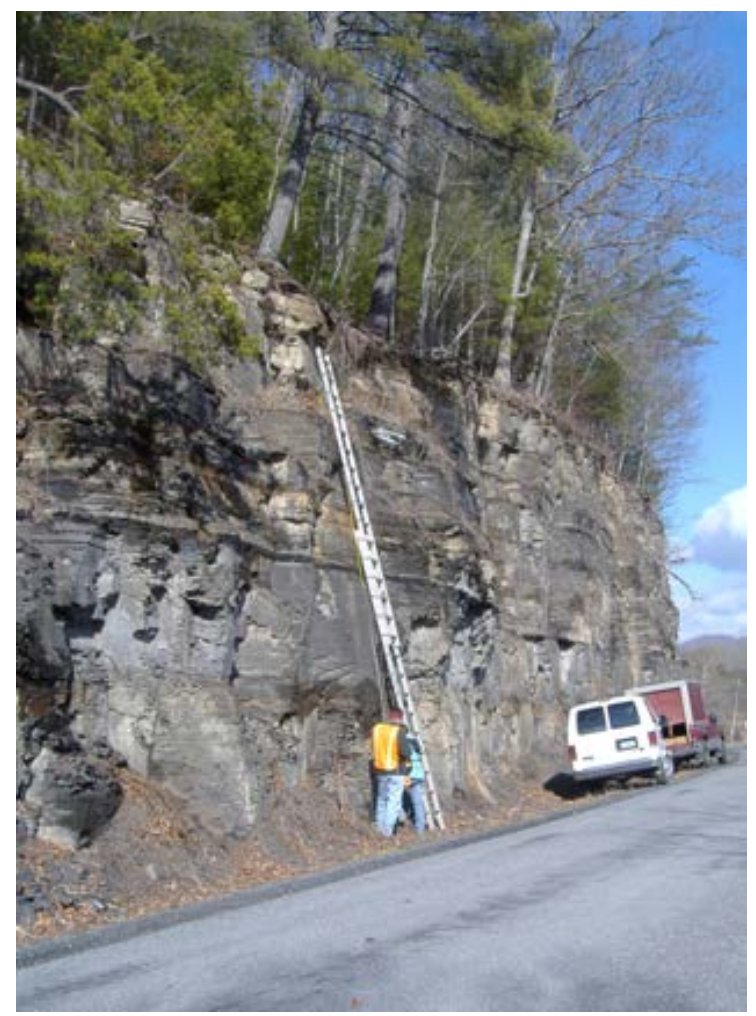

Figure 25. Obtaining a synthetic gamma ray log of the Millboro Shale on S.R. 678 south of Clover Creek. This exposure, at stop 3, is nearly horizontally bedded, and very little structural deformation is evident. Photo: Richard Lambert, Virginia Speleological Survey (VSS). 


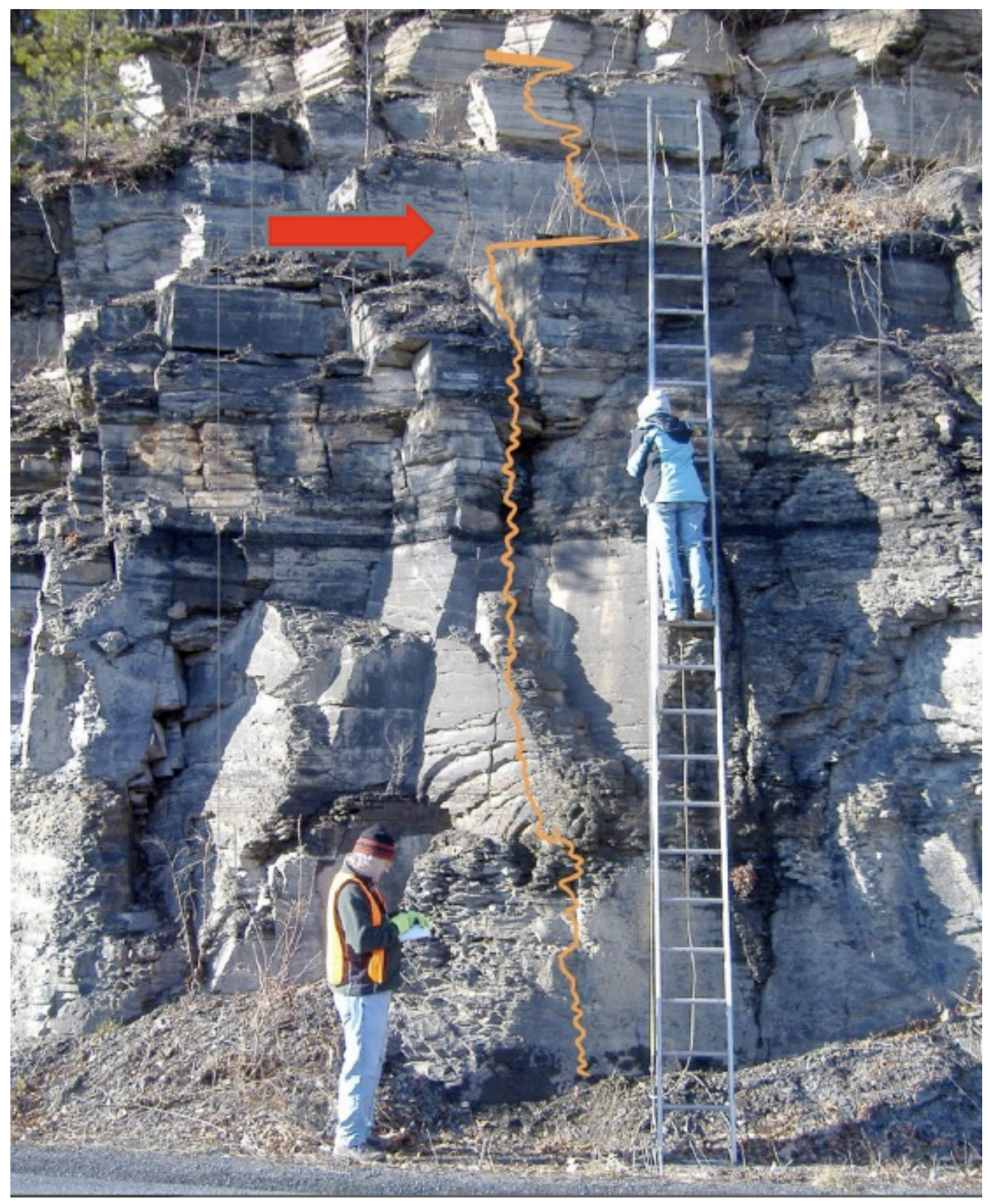

Figure 26. The synthetic gamma ray log of the Millboro Shale that was obtained from the outcrop at stop 3 in February 2011 is overlain on the exposure itself. The arrow is at the horizon of the major observed kick in counts per second and probably marks the location of the zone of highest organic content in this exposure. John Haynes and James Madison University student Sharon Porter are shown in photo. Photo: Richard Lambert, VSS. 
On the west side of S.R. 678 about $5.5 \mathrm{~km}$ northeast of stop 3 is another exposure of Marcellus (Millboro) Shale (fig. 27), but unlike the one farther south along S.R. 678, structural complications are visible at this exposure, as well as more stratigraphic variability. Near the north end of this exposure, almost at eye level along the road, is a fault zone that extends across much of the exposure and which thins and thickens measurably along its length (fig. 28). Faultinduced foliation within this zone is tangential to the overlying and underlying undeformed shale, indicating overall west-directed thrust movement. Above this zone are intervals with many concretions (figs. 29, 30).

At the south end of this exposure is a road-level-accessible bed that is about $30-40 \mathrm{~cm}$ thick and which is notably more resistant, thicker bedded, and lighter in color than the adjacent mudrocks (fig. 31). This is a calcareous bed with abundant barite and quartz, making it somewhat similar in terms of its mineral content to the concretions that occur in the Marcellus Shale of this region. This bed has been slightly folded at places along its length, giving it a broadly undulatory character, and it has also been broken by small faults in two places (fig. 32). Some faults appear to truncate and offset prominent joints, suggesting that at least some of the joint sets predate the main phase of Alleghanian thrust faulting (for example, Engelder and Whitaker, 2006). This may be the Purcell Member of the Marcellus Shale, which is noted for its barite content (Nuelle and Shelton, 1986; Hasson and Dennison, 1988).

\section{Exposure of Millboro Formation along Bullpasture River, Va.}

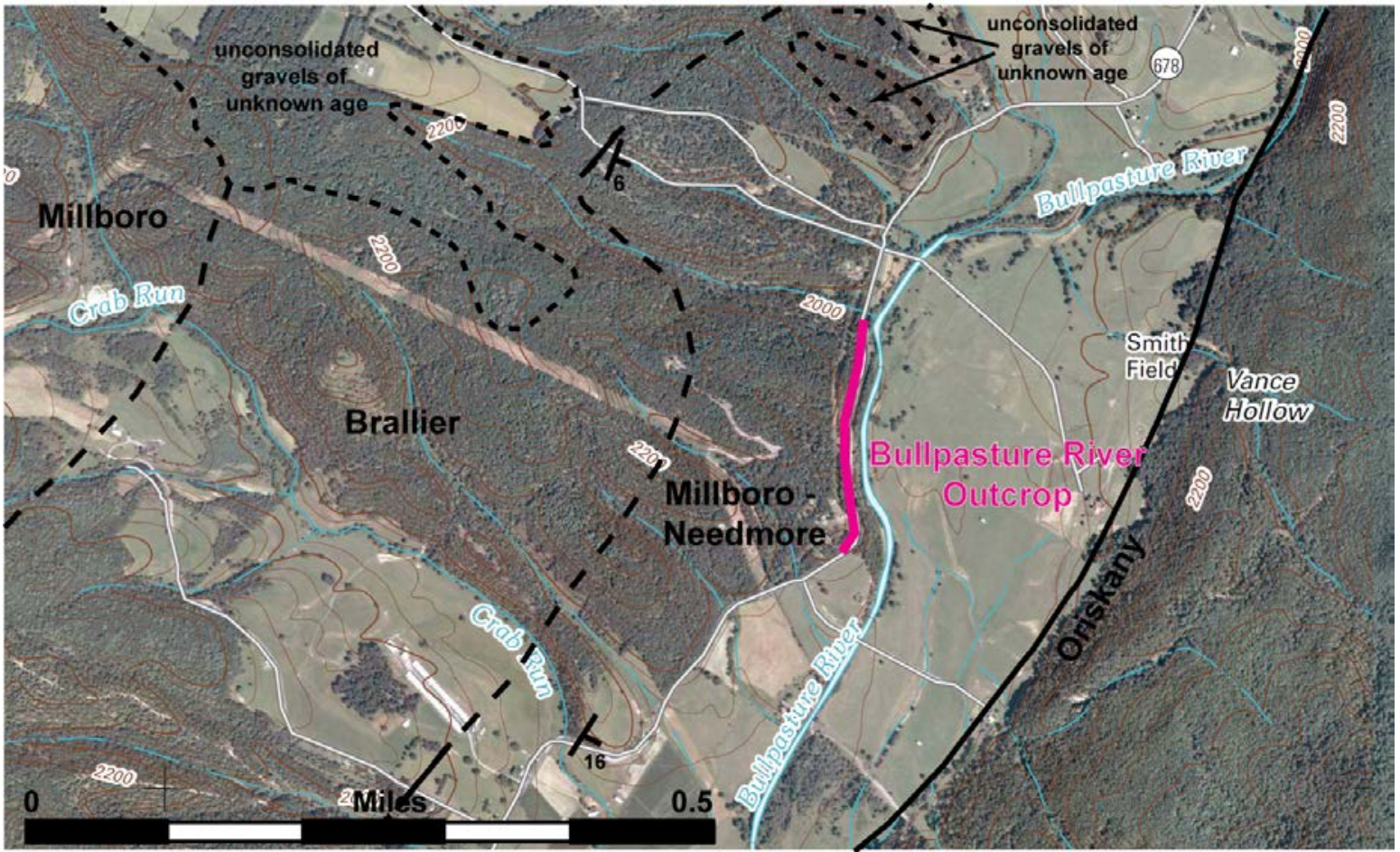

Figure 27. Sketch geologic map of stop 4 area showing Devonian Oriskany Sandstone to Brallier Formation; base map is VA_Monterey_SE_20110510_TM_geo.pdf, available from the USGS Map Store (http://store.usgs.gov); geologic annotation from unpublished field maps of G.P. Wilkes, DMME, and J.L. Coleman and C.S. Swezey. 


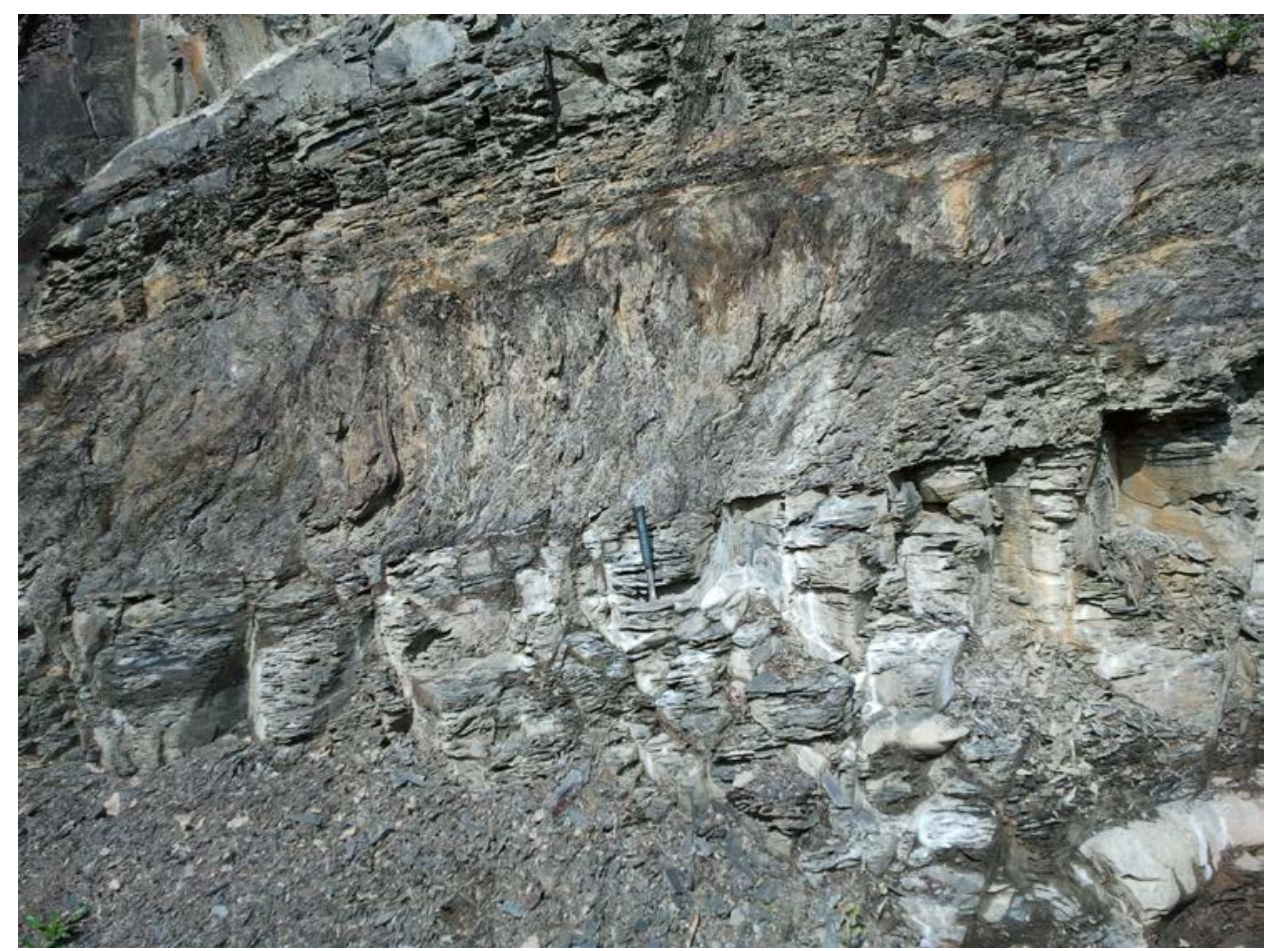

Figure 28. Fault zone (across center of photo) at stop 4 containing shear-banded shale bounded by zones of relatively undeformed shale above and below. Configuration of material indicates dextral movement of the shale blocks relative to one another. Rock hammer is $33 \mathrm{~cm}$ long. Photo: Diana Rotter.

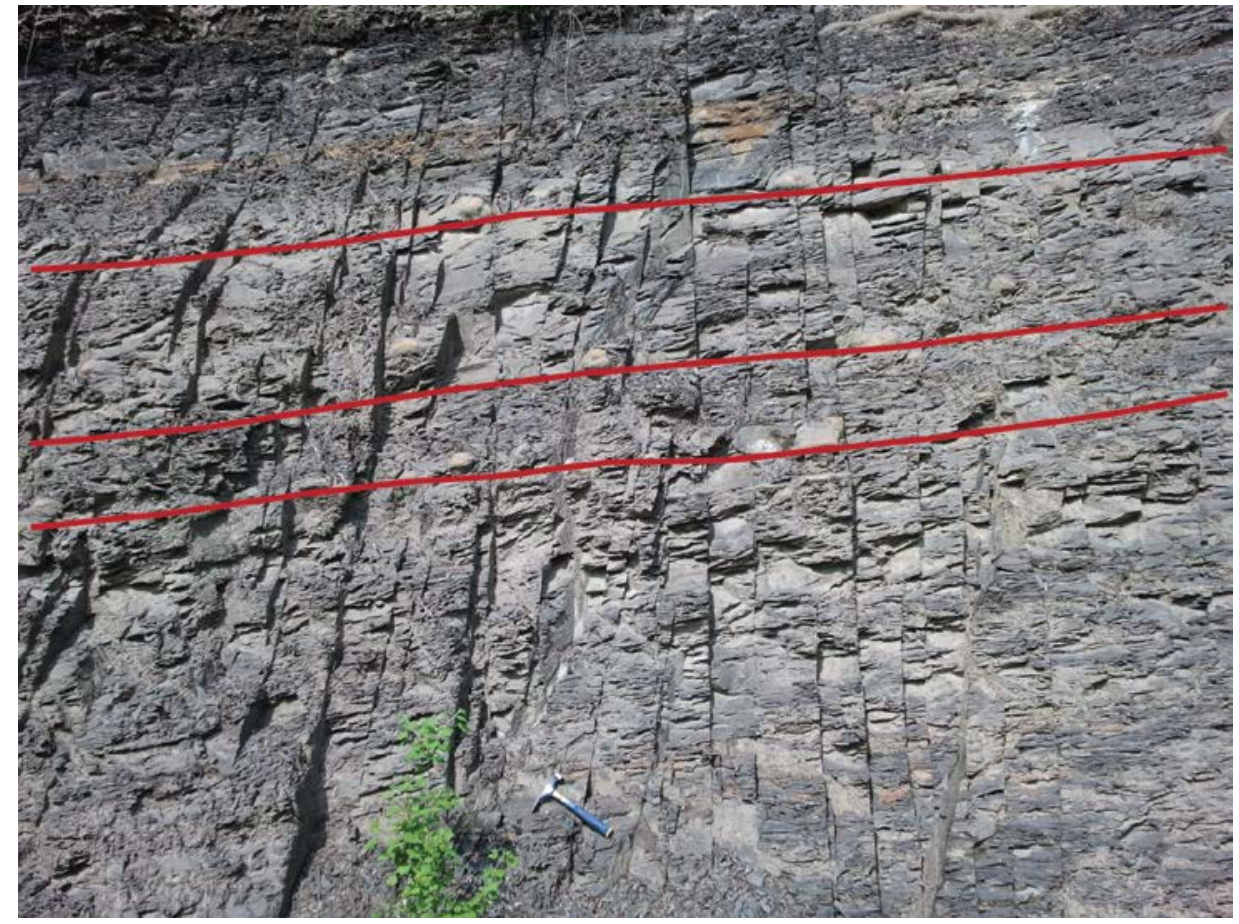

Figure 29. In this exposure of the Marcellus Shale at stop 4, concretions are arranged in distinct layers, as indicated by the red lines. In some cases, joints have cut and displaced portions of some concretions; in other instances, joints have stopped or "bent" around concretions. Rock hammer is $33 \mathrm{~cm}$ long. Photo: Diana Rotter. 


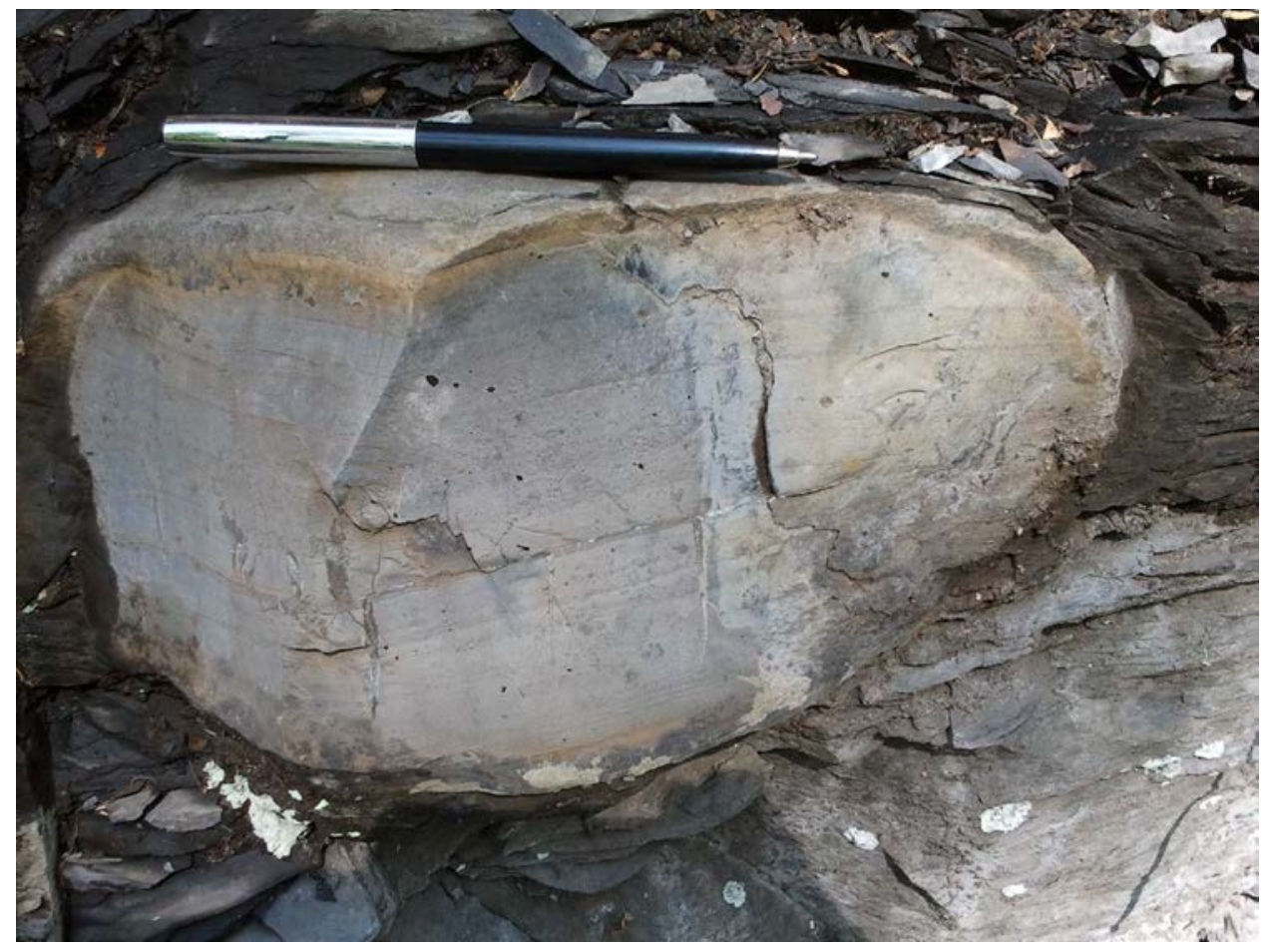

Figure 30. Some concretions contain parallel layering internally, suggesting primary sedimentation layers. In this calcium carbonate-rich concretion, the formational layers are made obvious by the weatherresistant nature of the pyrite crystals. Photo: Diana Rotter.

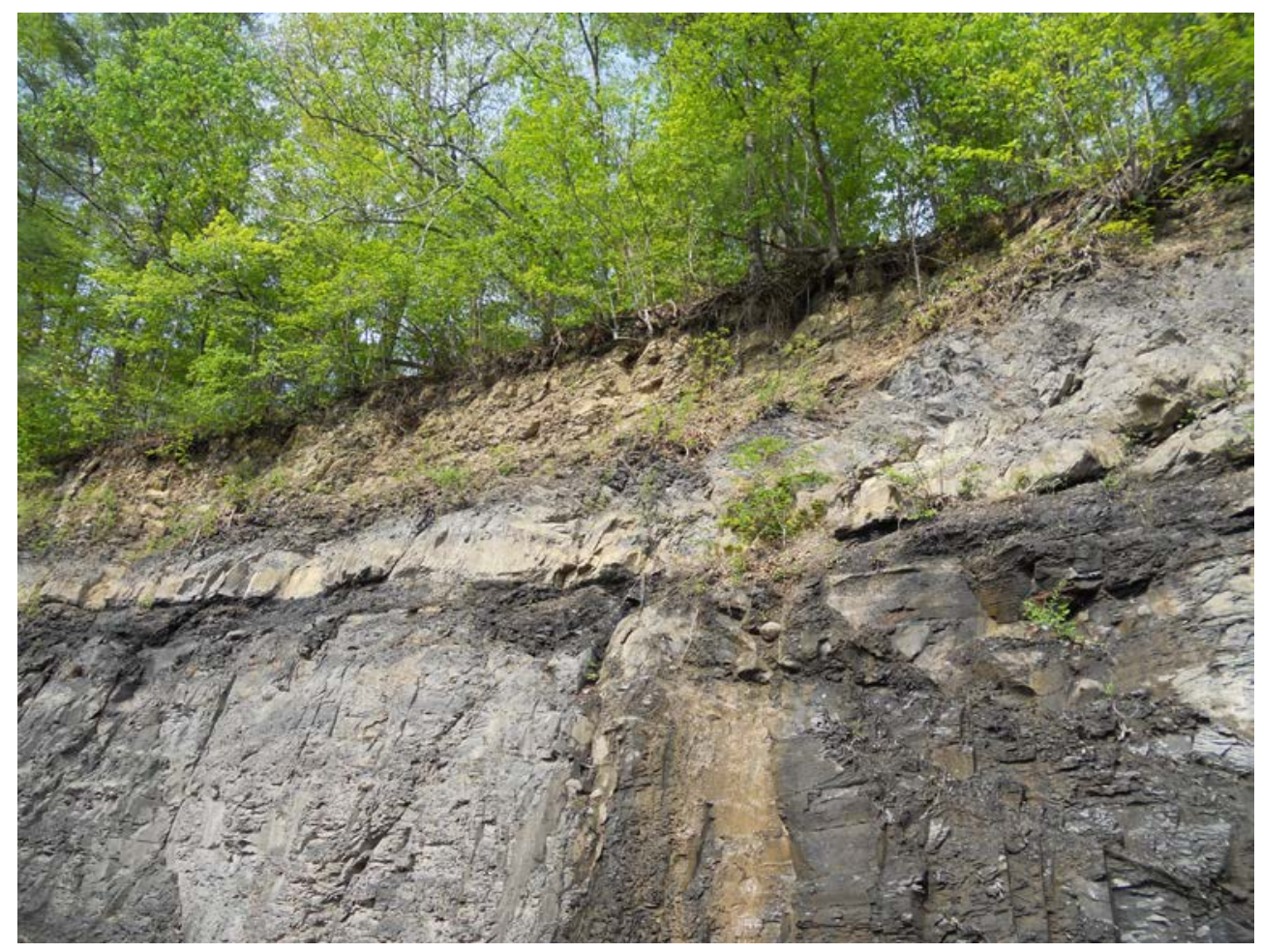

Figure 31. Light-colored, calcareous barite-rich bed (located in upper third of roadcut) within Marcellus (Millboro) Shale at stop 4. Photo: Catherine Enomoto. 


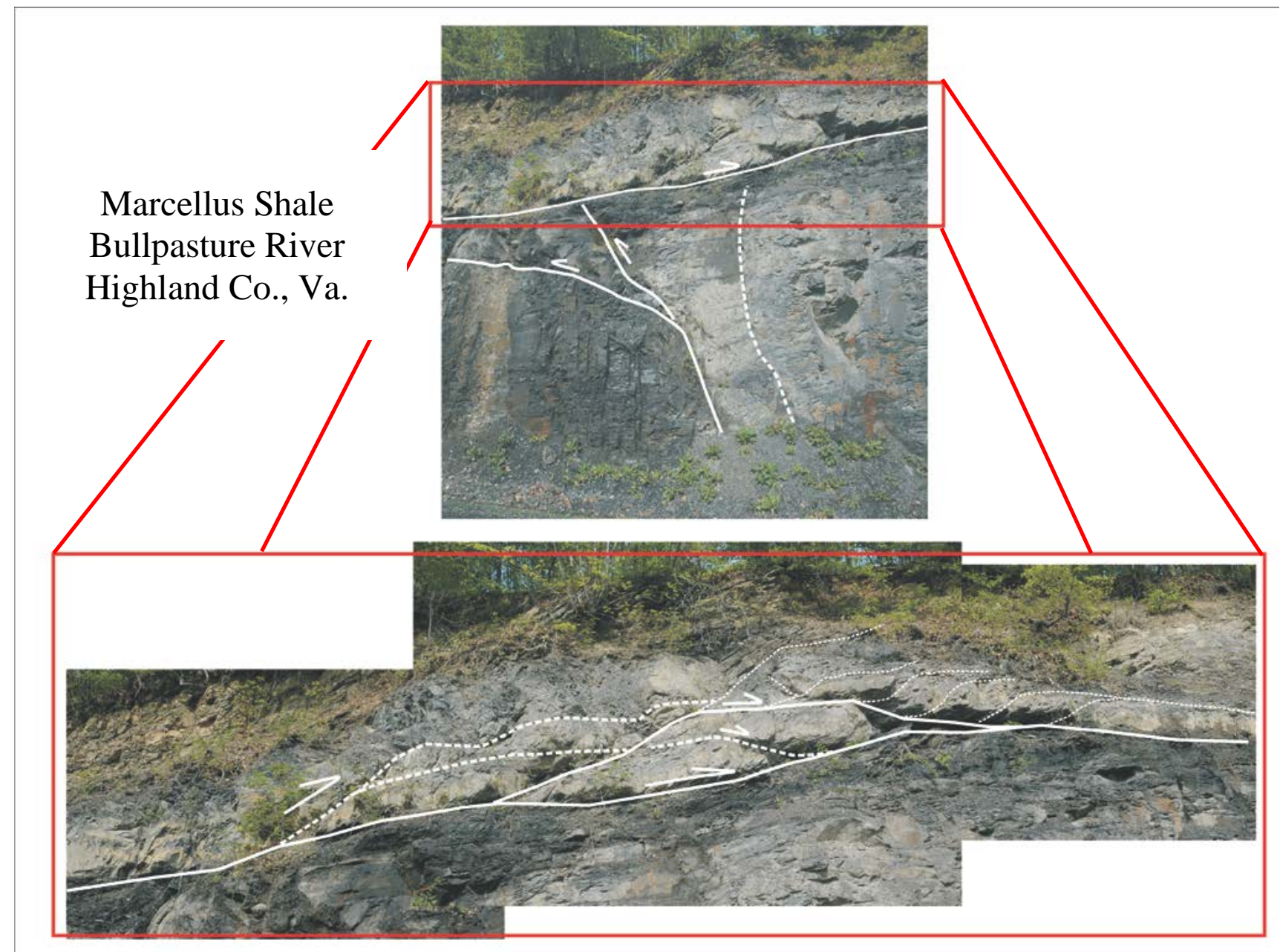

Figure 32. Folded and faulted calcareous, barite-rich layer of the Marcellus Shale at Bullpasture River. It is underlain by a $25-\mathrm{cm}$-thick shale interval that is sheared, which is subsequently underlain by a shale interval with no lateral shearing characteristics. Photo and graphics: James Coleman.

\section{Bullpasture Mountain}

Stop 5: Northwest limb of McClung syncline, U.S. 250, Bullpasture Mountain (N. 38.3255², W. $79.443617^{\circ}$ ) Strike N. $44^{\circ}$ E., Dip $47^{\circ}$ SE.

A stratigraphic section from the Lower Devonian Oriskany Sandstone to the Middle Devonian Millboro Shale is exposed on the east flank of Bullpasture Mountain where U.S. 250 traverses generally east to west across Highland County (fig. 33). When the highway was originally constructed, it incised Bullpasture Mountain east of McDowell, Va. In the mid-1990s, part of the highway was straightened, including the portion that exposes the Marcellus Shale. The original roadbed, as well as the current highway roadcut, allows access to the Middle Devonian section from the lower part of the Needmore Shale to the upper part of the Millboro Shale (figs. 33-37). Exposures along the highway continue east of the Cowpasture River valley and contain uppermost Millboro (Mahantango Formation siltstone and shale) and lower Brallier sandstone, siltstone, and shale. The presence of erosion control material covering a significant portion of the current roadcut west of the Cowpasture River (fig. 37), however, inhibits examination of the Tioga Ash Bed and the lowermost portion of the Millboro Shale that is correlative with the lower Marcellus Shale. A relict exposure in the parking area (shown as "Stop 
5” on figs. 34, 35) contains a small interval of material that is covered by the limestone boulders in the main cut. Heavy rain run-off in the spring of 2011 revealed more extensive exposures of this correlative interval in the drainage ditch along the toe of the limestone-armored slope on the north side of the highway, confirming the stratigraphic correlation with the exposures in the field trip stop 5 parking area. Hasson and Dennison (1988) described four limestone horizons within the Millboro Shale at this location. Today we are able to discern three calcareous horizons in the Millboro Shale and a limestone concretion horizon in the Needmore Shale. We will visit the thickest calcareous interval (fig. 36), which is being studied by the USGS to discern its age and depositional environment.

Representative samples were collected and submitted for geochemical analysis and for determination of low-temperature ash and semi-quantitative mineralogy by the USGS laboratory in Reston, Va. Results of the total organic carbon and vitrinite reflectance analyses are shown in figures 34 and 35. Thickness measurements taken in 2009 were compared with the description of the formations exposed in the original roadcut in Hasson and Dennison (1988) and with a sketch map made from earlier plane-table mapping of the original roadcut area published by Dennison (2005) (fig. 38).

\section{U.S. 250 at Bullpasture Mountain}

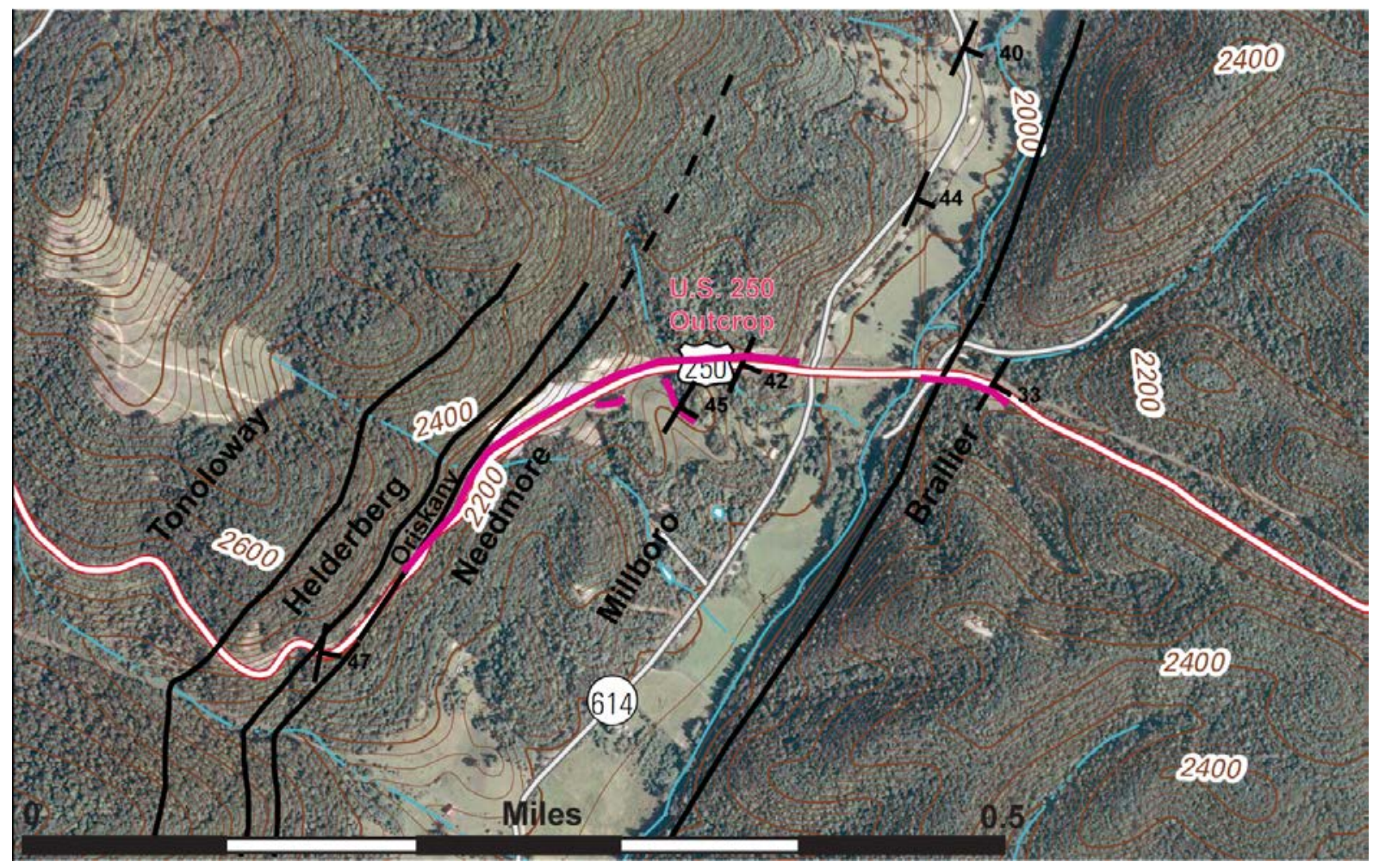

Figure 33. Sketch geologic map of stop 5 area showing Silurian Tonoloway Limestone to Devonian Brallier Formation, U.S. 250 at Bullpasture Mountain; base map is VA_McDowell_20110510_TM_geo.pdf, available from the USGS Map Store (http://store.usgs.gov); geologic annotation from unpublished field maps of G.P. Wilkes, DMME, and J.L. Coleman, C.S. Swezey, C.B. Enomoto, and P.W. Niemeyer. 


\section{Stop 5: Total Organic Carbon, weight \%}

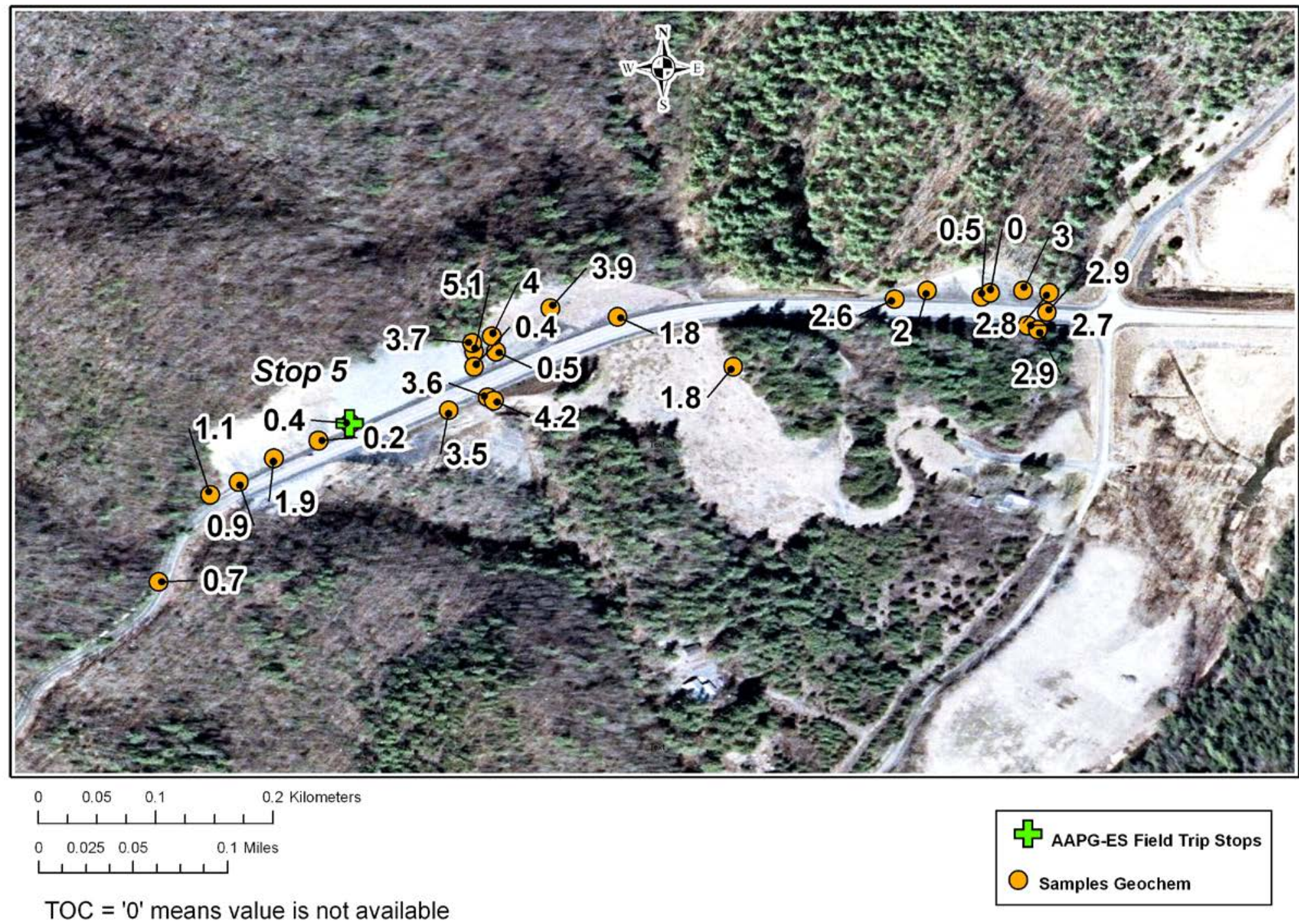

Figure 34. Aerial photograph of stop 5 depicting sample locations and total organic carbon values (weight percent) measured in all samples. 


\section{Stop 5: Vitrinite Reflectance, \%Ro}

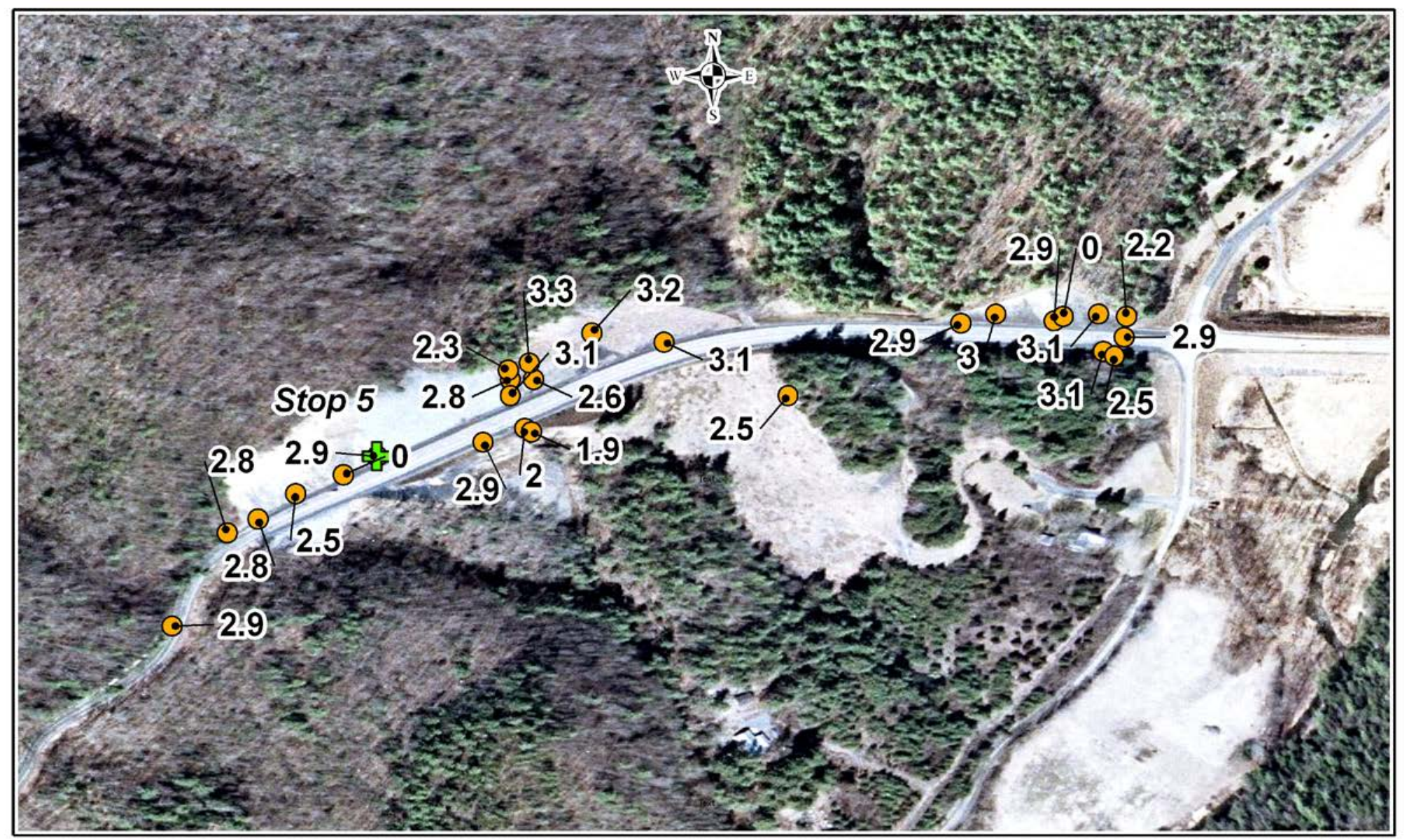

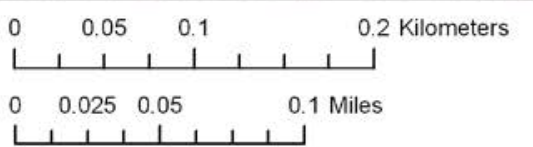

$\%$ Ro $=$ ' 0 ' means value is not available

Figure 35. Aerial photograph of stop 5 depicting sample locations and vitrinite reflectance values (\%Ro) measured in all samples. 


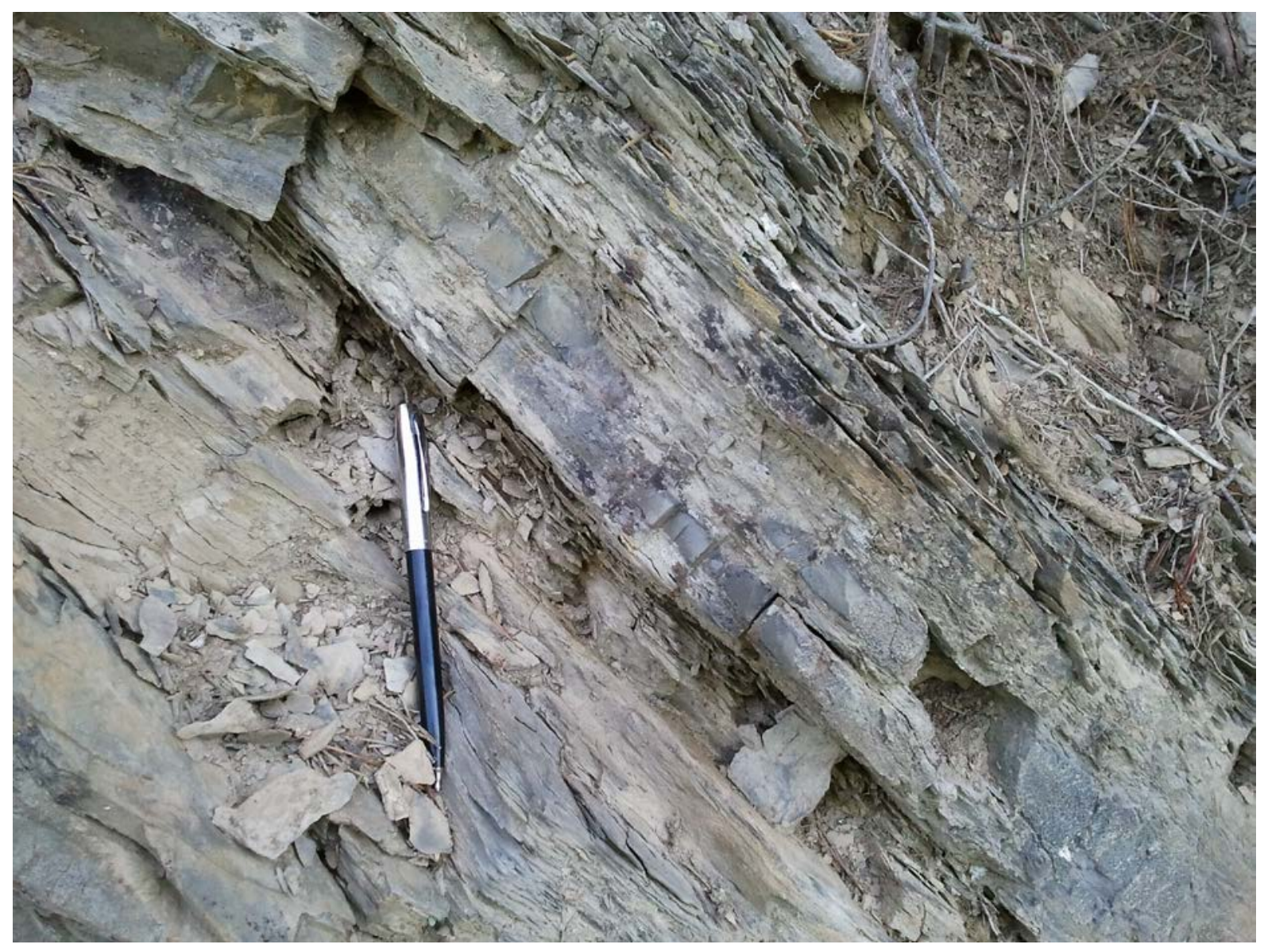

Figure 36. At stop 5, a 10.5-m-thick interval of interbedded silty limestones, calcareous shales, and silty shales may represent the Purcell Member of Millboro Shale. Samples were collected to attempt to determine the conodont zonation for this interval. Photo: Diana Rotter. 


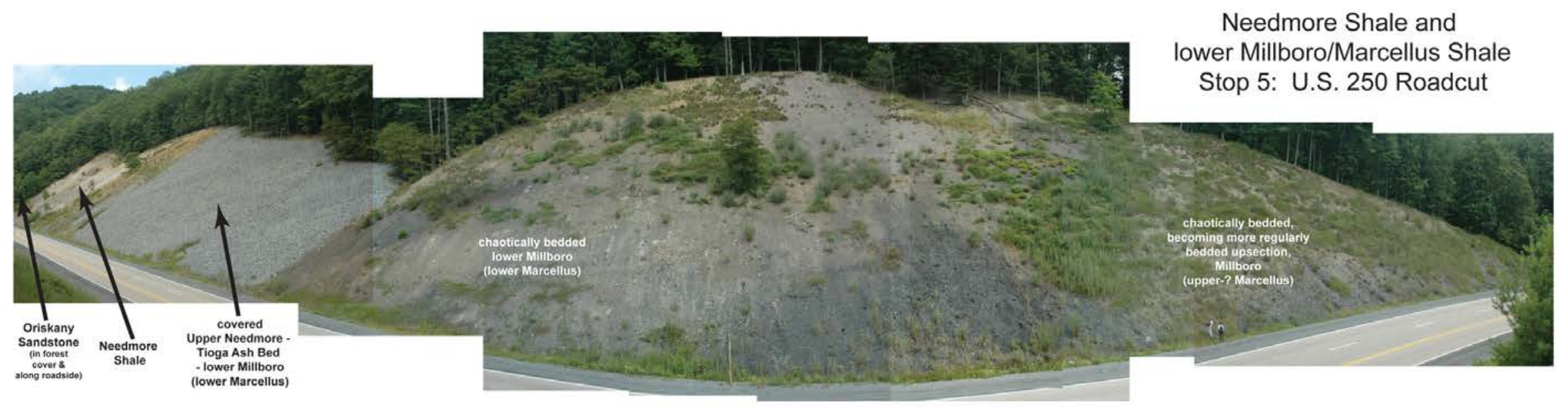

Figure 37. Photomontage of western portion of U.S. 250 roadcut at stop 5. This view extends from the Lower Devonian Oriskany Sandstone (exposed in the woods at the left of the image) through the Middle Devonian Needmore Shale to a covered interval beneath which lies the upper Needmore Shale,

Tioga(?) Ash Bed, and lower Millboro (lower Marcellus) Shale (Middle Devonian). Downhill, to the right of the montage (up section, stratigraphically), the upper Marcellus Shale and lower Mahantango Formation (upper Millboro Shale) are well exposed. A significant amount of erosion control material covers this exposure of the Marcellus Shale at stop 5 along the highway on Bullpasture Mountain. This riprap is placed over highly deformed Tioga(?) Ash Bed and lower Millboro Shale to prevent landslides from blocking U.S. 250. Photos: James Coleman. 


\section{Middle Devonian Stratigraphy}

Highland County, Virginia

Vertical Section at U.S. 250 and Cowpasture River, Highland Co., Va. (Hasson and Dennison, 1988)

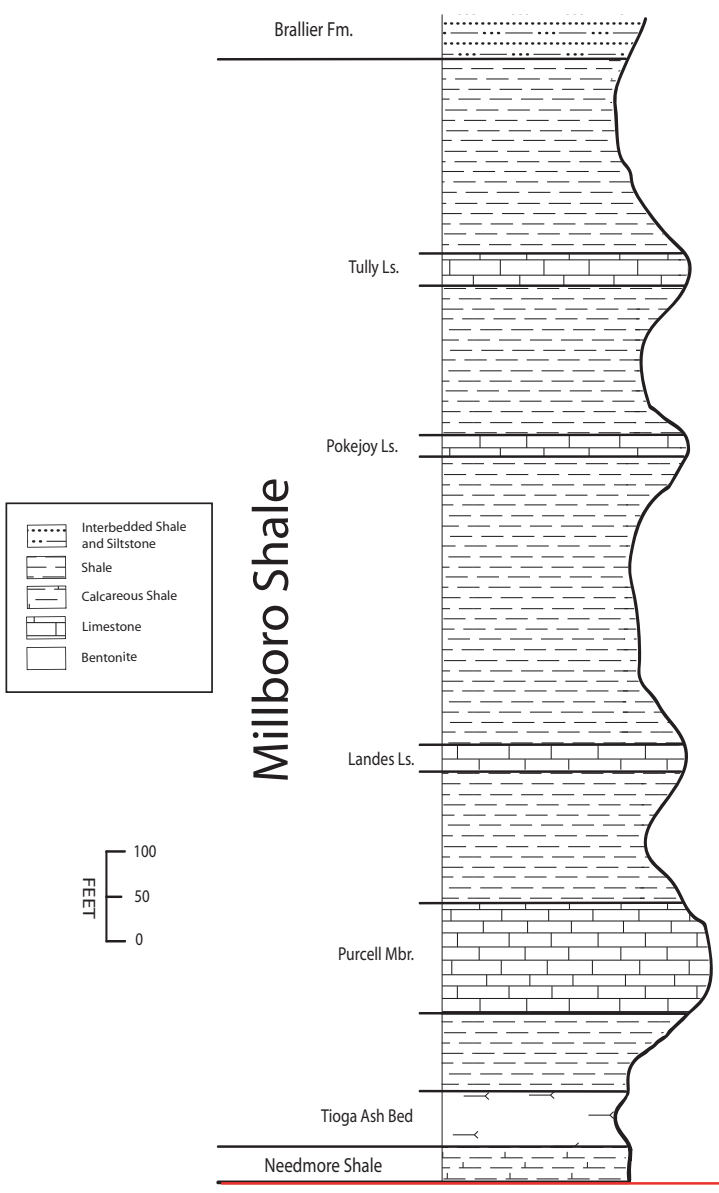

Section constructed by Patrick Niemeyer from information contained in Hasson and
Vertical Section at U.S. 250 and

Cowpasture River, Highland Co., Va.
Bertha Smith \# 1

Highland County, Va.

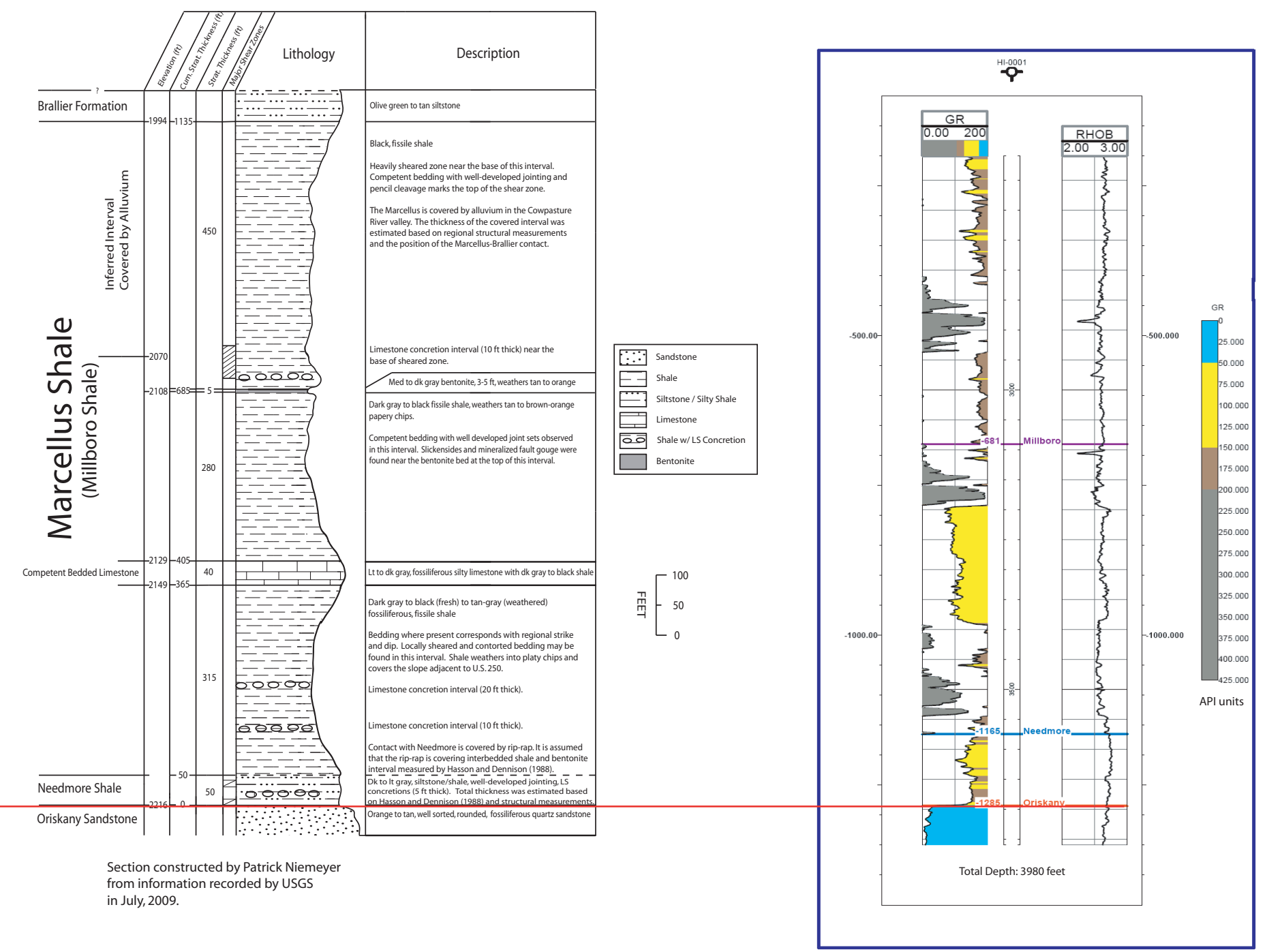

Figure 38. Graphical representation of measured sections of old (Hasson and Dennison, 1988) and new road beds correlated to geophysical log of nearby exploration well. Graphics by Patrick Niemeyer and Catherine Enomoto. Fm. = Formation; Ls. = Limestone; GR = gamma ray; $\mathrm{RHOB}=$ bulk density. 


\section{South Branch of the Potomac River}

\section{Stop 6: Northwest limb of syncline, U.S. 33 north of Brandywine, W.Va. (N. 38.6337 ${ }^{\circ}$, W. $79.2313^{\circ}$ ) Strike N. $35^{\circ}$ E., Dip $25^{\circ}$ SE.}

The geologic maps (figs. 39-41) indicate that the location of this stop is in the upper part of the Millboro Shale, near the contact with the Brallier Formation. Predominantly dark-gray to black, thinly bedded carbonaceous shale, interbedded with several thin limestones, is present at this location (figs. 42-43). Continuous limestone beds, approximately $15-30 \mathrm{~cm}$ thick, are located midway up the exposure on the east side of the highway. Underlying this interval is a dolomitic bed that has an erosional basal contact and sharp top contact and contains features that exhibit an overall "bell shape"; these features may represent some type of soft sediment deformation (fig. 44). Examination of thin sections made from samples taken in dark laminae associated with these sedimentary features shows that the laminae are composed of iron-rich clay and framboidal pyrite, suggesting that some of these laminae originated as thin layers of organic matter, perhaps of algal origin. A layer of calcareous concretions, some with well-developed septaria (fig. 43), is located midway up the exposure on the west side of the highway; this interval is lower stratigraphically than the interval on the east side of the highway. Also on the west side of the highway are thin quartz silt laminae, cemented with calcite, interbedded with black carbonaceous shale (fig. 45). Low-relief cross-bedding is evident in silt laminae within the shale. Faint feeding traces are present as well as a dwarfed fauna of articulate brachiopods (Leiorhynchus sp.); conical, phosphatic fossils (Styliolina fissurella); and unidentified goniatite cephalopods. The dominant joint set is oriented at 50 degrees northwest (fig. 46), with a secondary joint set oriented 55 degrees northeast.

As the field trip vehicles proceed east out of the field trip area to the top of Shenandoah Mountain, we will drive through the Brallier, Scherr, Foreknobs, and Hampshire Formations (Dennison, 1988; fig. 47). 

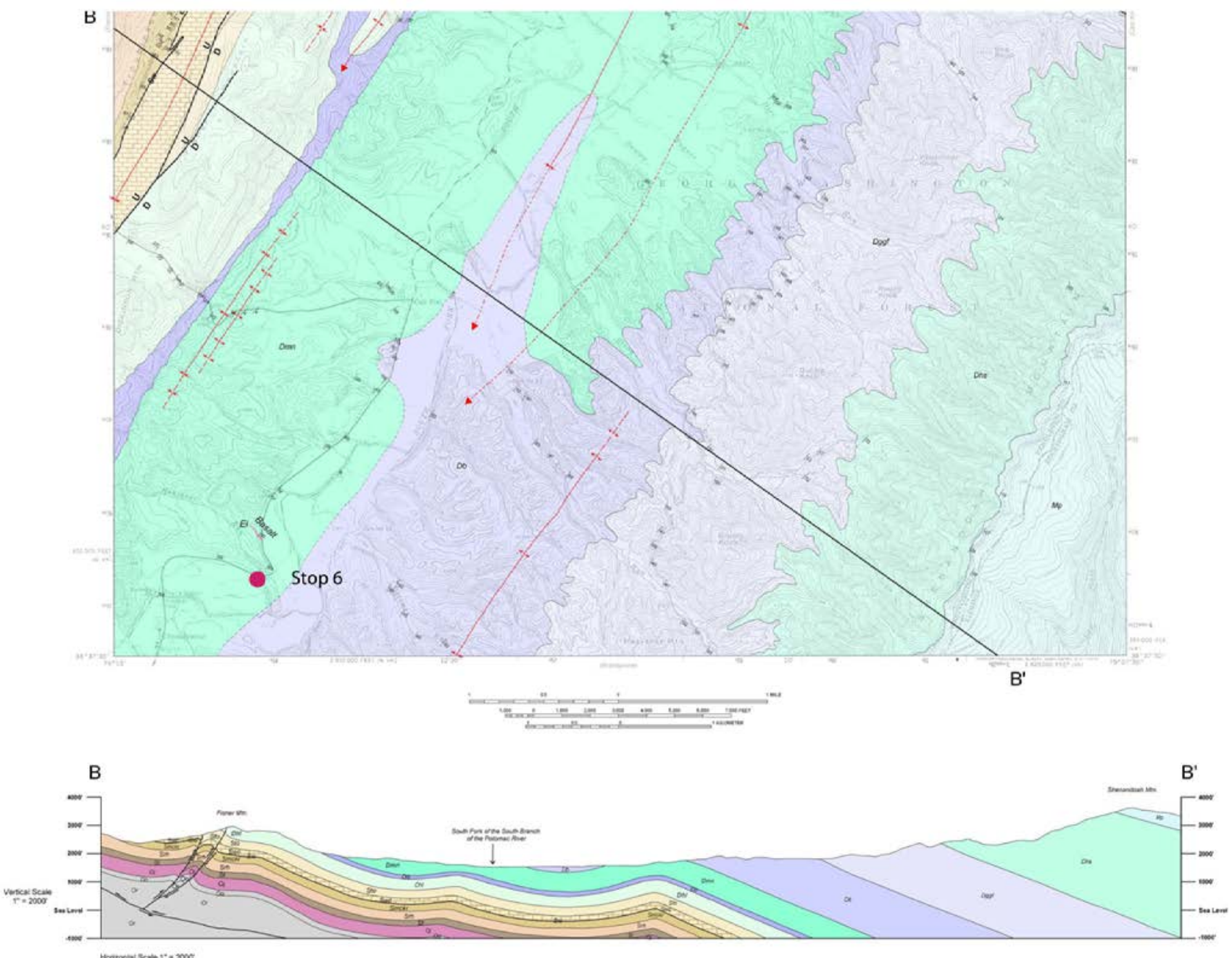

Mp = Mississippian Price Formation

Dhs $=$ Devonian Hampshire Formation

Dggf = Devonian Greenland Gap/Foreknobs Formation
$\mathrm{Db}=$ Devonian Brallier Formation

Dmn $=$ Devonian Millboro \& Needmore Shales

Do $=$ Devonian Oriskany Sandstone

Dhl $=$ Devonian Helderberg Group

Figure 39. Southern half of the geologic map and cross section of the Fort Seybert 7.5-minute quadrangle, W.Va. (modified from McDowell and others, 2007) 


\section{Stop 6: Total Organic Carbon, weight \%}

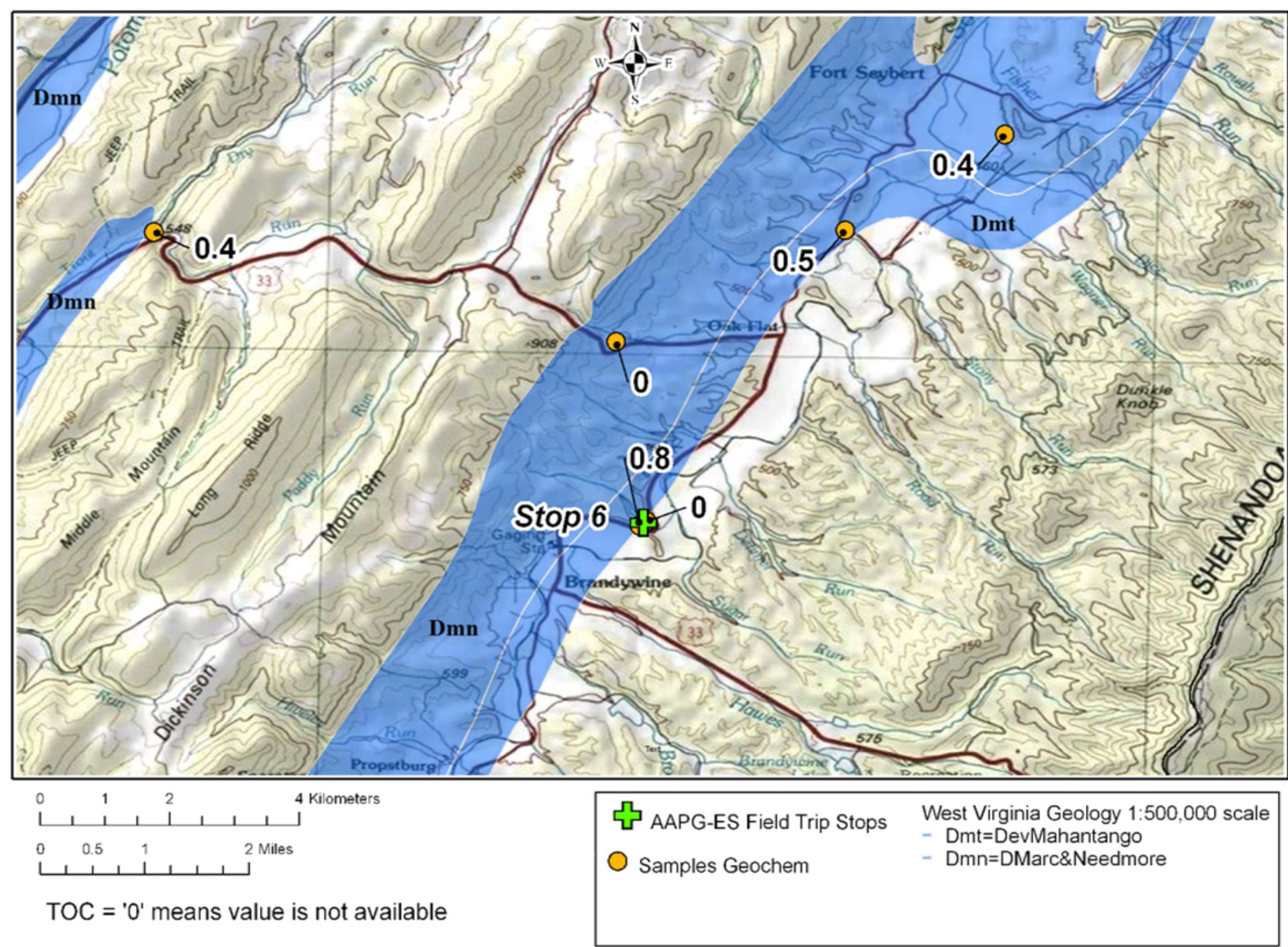

Figure 40. Index map of stop 6 on topographic base with total organic carbon values. Outcrop belt of Devonian formations, including the Mahantango, Marcellus, Millboro, Needmore, and Huntersville Chert, is shown in blue, from 1:500,000-scale digital geologic map (modified from Nicholson and others, 2005). Total organic carbon values (weight percent) posted next to sample locations. 


\section{Stop 6: Vitrinite Reflectance, \%Ro}
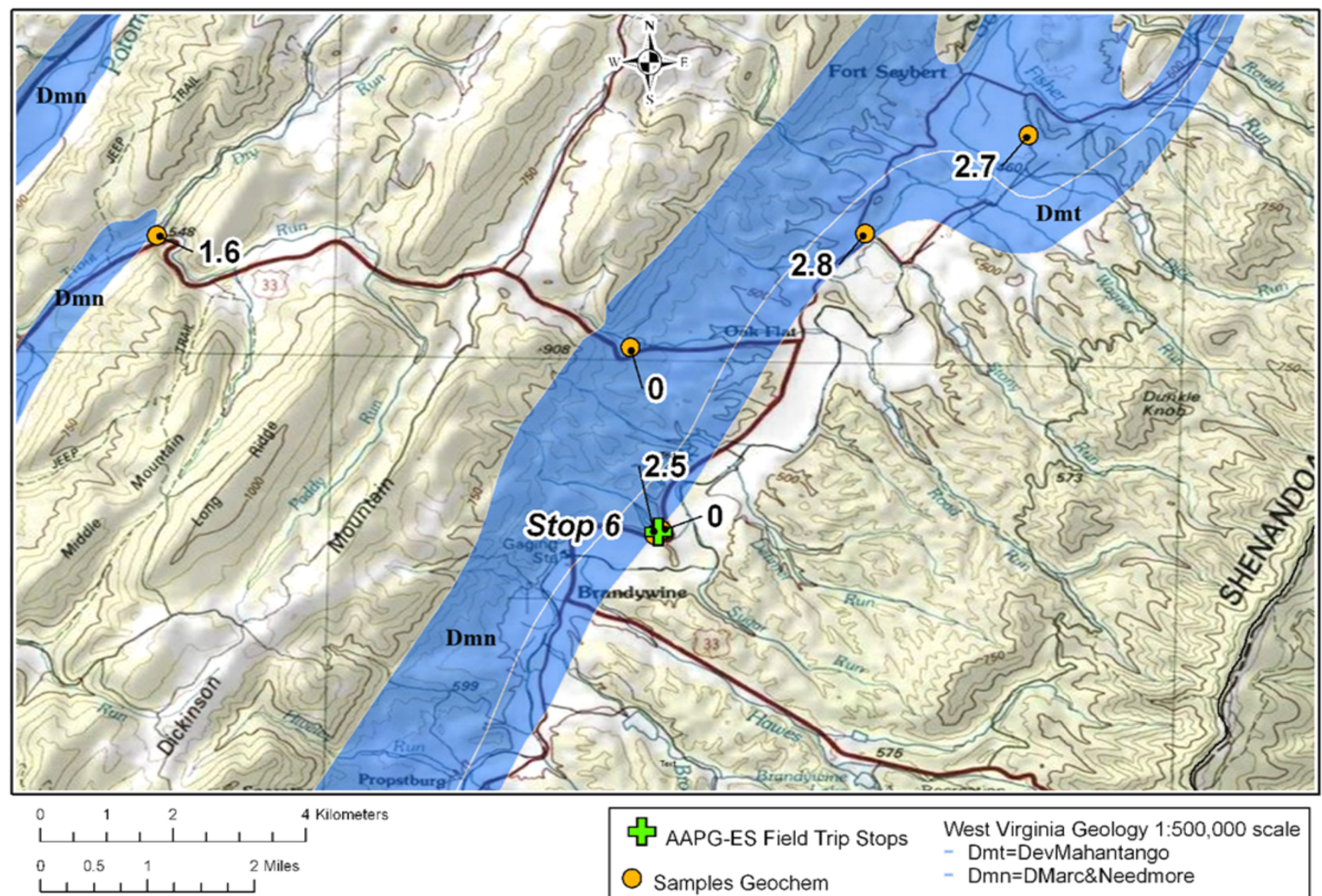

$\%$ Ro $=$ ' 0 ' means value is not available

Figure 41. Index map of stop 6 on topographic base with vitrinite reflectance values. Outcrop belt of Devonian formations, including the Mahantango, Marcellus, Millboro, Needmore, and Huntersville Chert, is shown in blue, from 1:500,000 scale digital geologic map (modified from Nicholson and others, 2005). Vitrinite reflectance values (\%Ro) posted next to sample locations. 


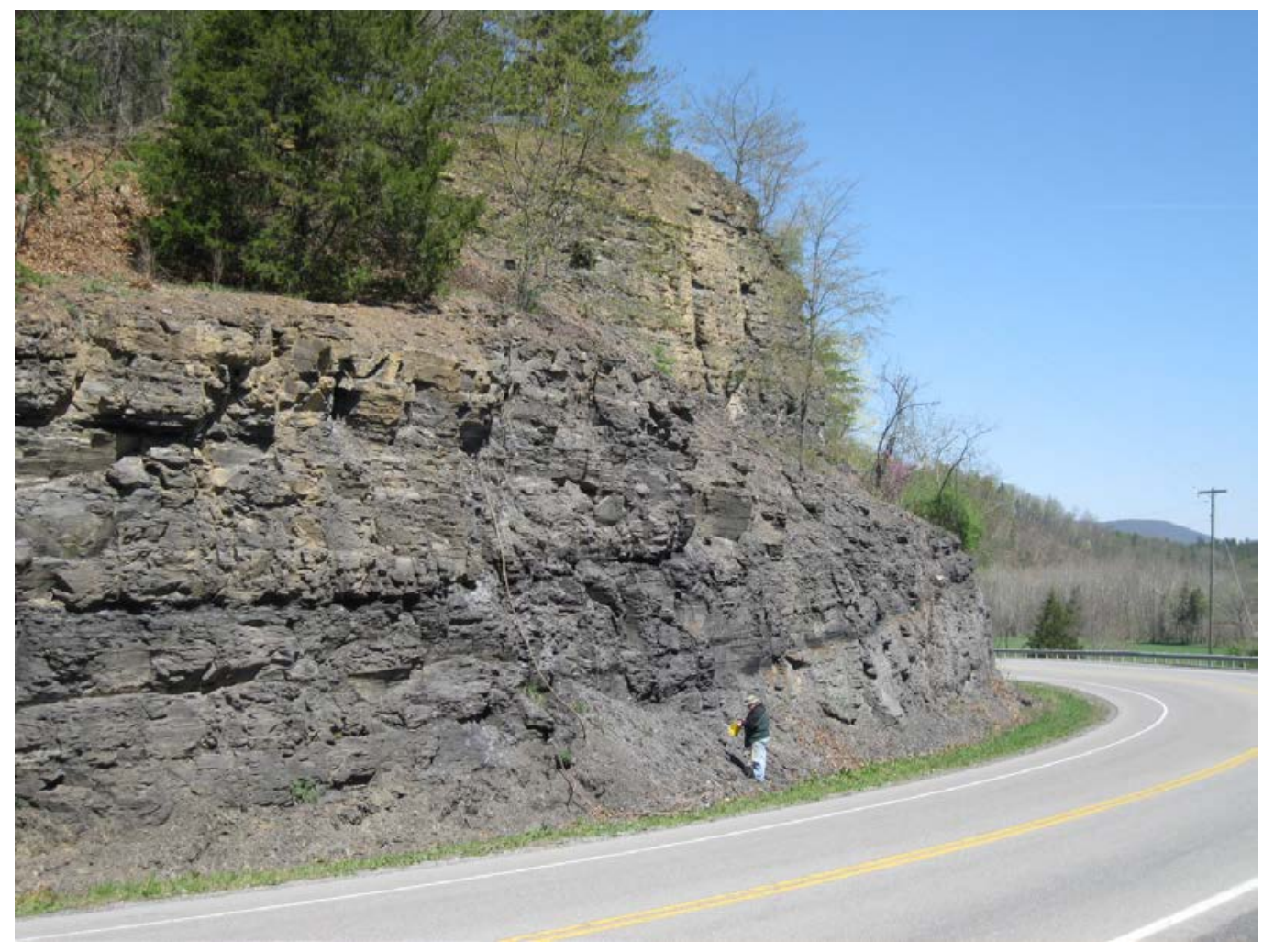

Figure 42. Brandywine outcrop (west side of U.S. 33). Photo: Eric Lewis.

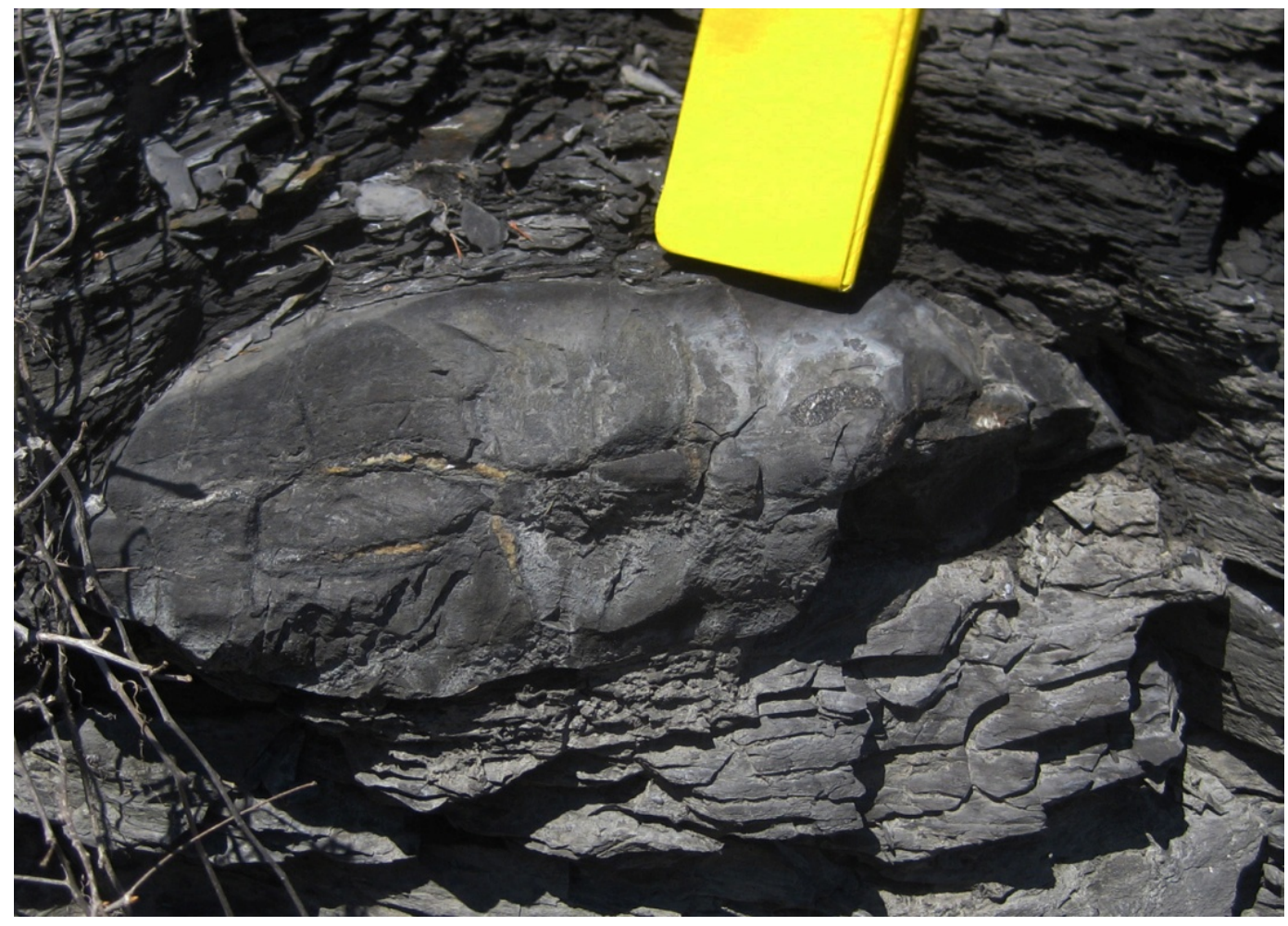

Figure 43. Carbonate concretion with septaria located on west side of U.S. 33. Note field notebook for scale. Photo: Ronald McDowell. 


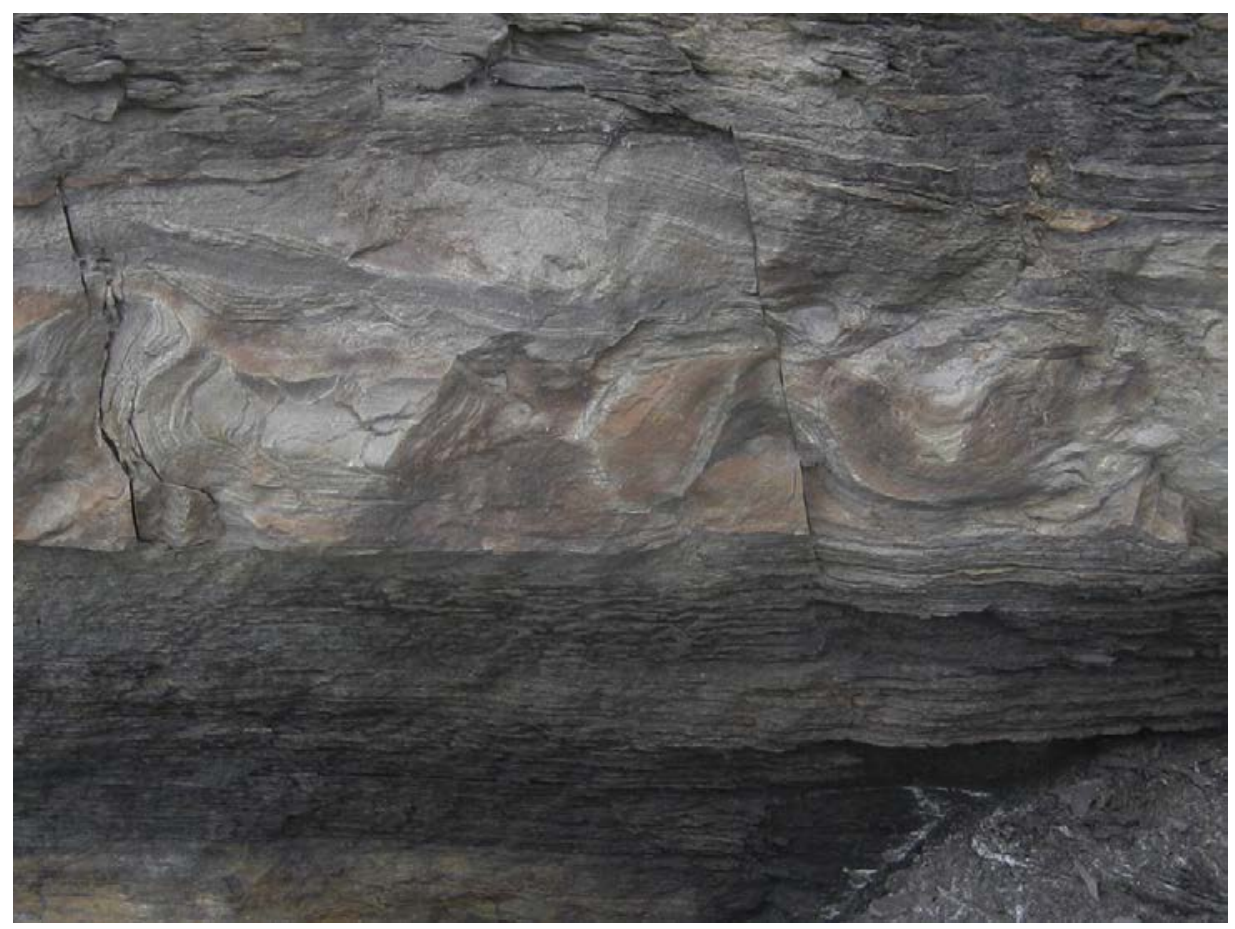

Figure 44. Small, soft-sediment structures or possible algal laminae in 25-cm-thick dolomitic layer on east side of U.S. 33. Interbedded carbonate and ripple cross-laminated quartz siltstone overlie this bed; horizontally laminated quartz siltstone underlies it. This feature exhibits many characteristics of an ancient seismite, namely, sudden formation, size, tectonic setting, and depositional setting (Wheeler, 2002). This feature's extent has not been mapped to determine if synchroneity and zoned distribution also satisfy the characteristics of an ancient seismite. Photo: Ronald McDowell.

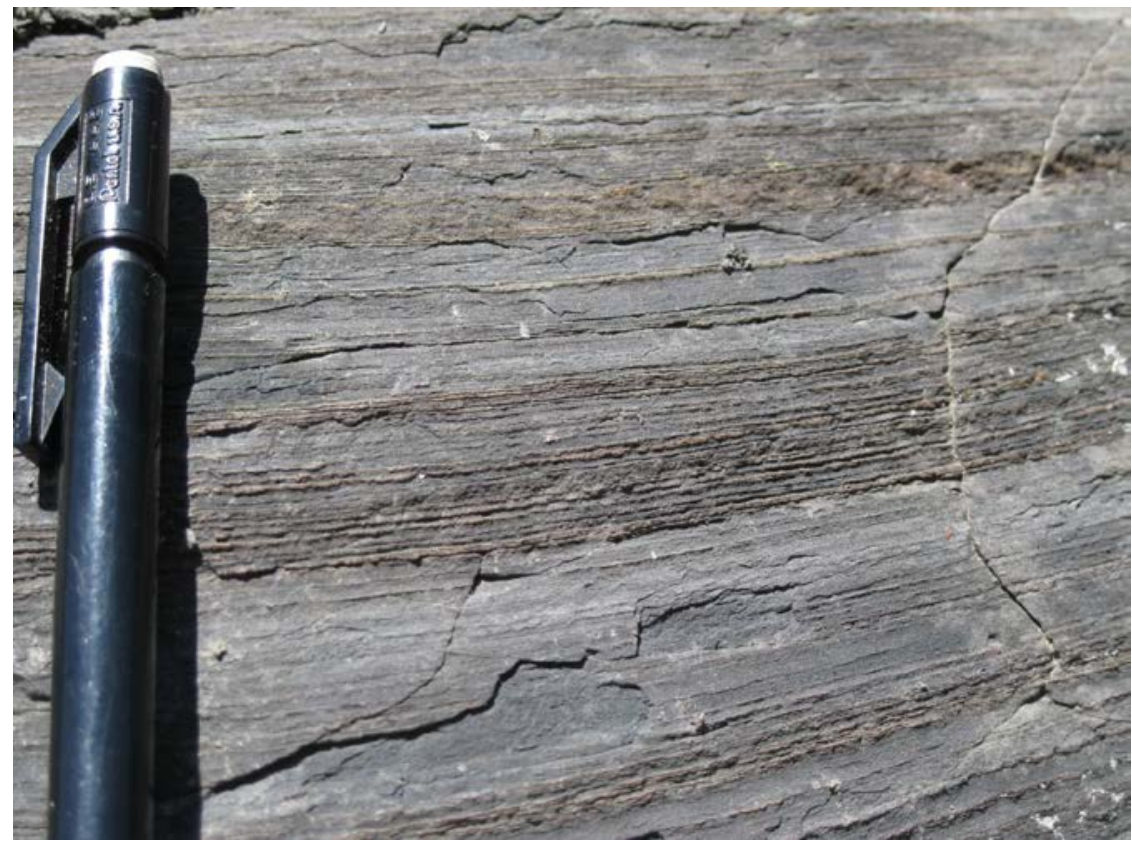

Figure 45. Quartz silt turbidite(?) laminae cemented with calcite on west side of U.S. 33. Photo: Eric Lewis. 


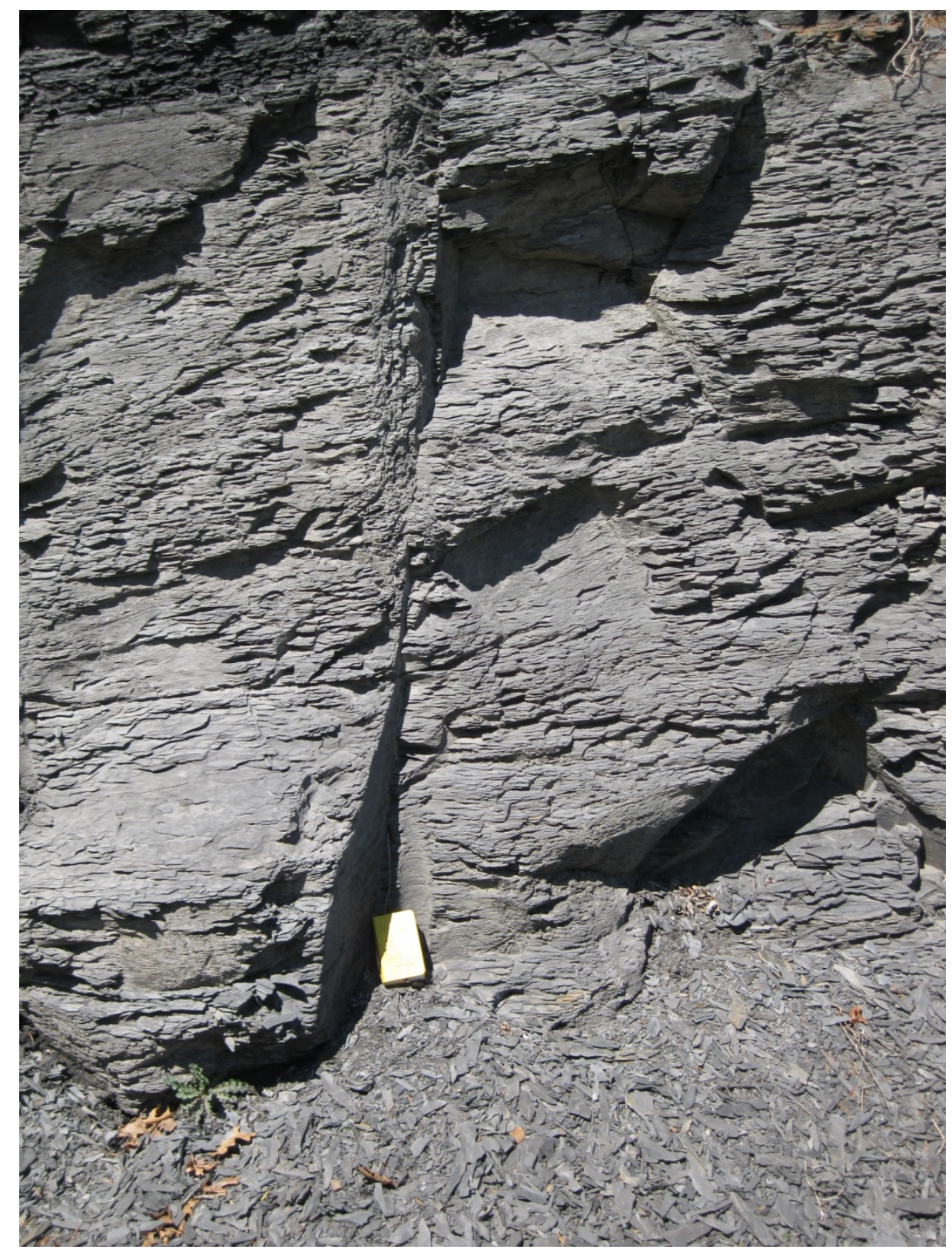

Figure 46. Well-developed joint in Millboro Shale with "splintery" fracture on west side of U.S. 33. Note field book for scale. Photo: Eric Lewis. 


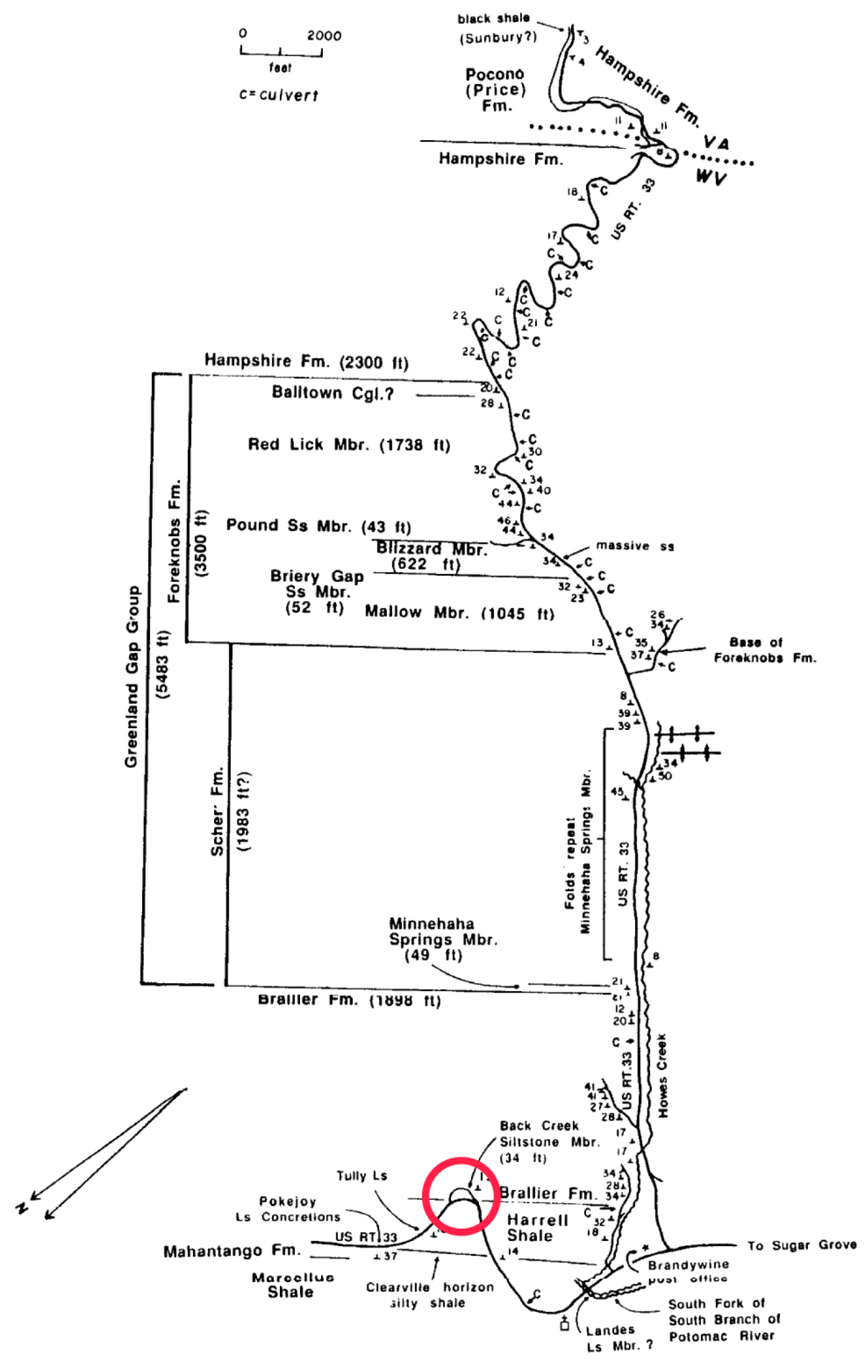

Figure 47. Plane-table map along U.S. 33 near Brandywine, W.Va. (Dennison, 1988). In this figure, Dennison differentiates the Marcellus Shale, Mahantango Formation, and Harrell Shale within the Millboro Shale. The red circle indicates the location of stop 6. 


\section{References Cited}

Bick, K.F., 1962, Geology of the Williamsville quadrangle, Virginia: Virginia Division of Mineral Resources, Report of Investigations 2, 40 p.

Butts, Charles, 1918, Geologic section of Blair and Huntington Counties, central Pennsylvania: American Journal of Science, ser. 4, v. 44, p. 523-537.

Butts, Charles, 1940, Geology of the Appalachian Valley in Virginia: Virginia Geological Survey Bulletin 52, part I - geologic text and illustrations, 568 p.

Cardwell, D.H., 1982, Oriskany and Huntersville gas fields of West Virginia, with deep well and structural geologic map: West Virginia Geological and Economic Survey, Mineral Resources Series, MRS-5A, $180 \mathrm{p}$.

Caro, Natalie, Walsh, Kimberley, Walker, S.M., Whitmeyer, S.J., and Haynes, J.T., 2010, Analyses of deformed zones in the Millboro Shale, Highland County, VA: Implications for Alleghanian Tectonics: 2010 Northeastern/Southeastern Joint Section Meeting of the Geological Society of America Abstracts with Programs, v.42, no.1, p. 91.

Cate, A.S., 1963, Lithostratigraphy of some Middle and Upper Devonian rocks in the subsurface of southwestern Pennsylvania, in Shepps, V.C., ed., Symposium on Middle and Upper Devonian stratigraphy of Pennsylvania and adjacent states: Pennsylvania Geological Survey General Geology Report, $4^{\text {th }}$ series, no. 39, p. 229-240.

Cecil, C.B., 2004a, Eolian dust and the origin of Devonian cherts in the Appalachian basin, USA [abs.]: Geological Society of America, Northeastern - Southeastern Section Joint Annual Meeting Abstracts with Program, accessed July 29, 2011, at http://gsa.confex.com/gsa/2004NE/finalprogram/abstract_69642.htm.

Cecil, C.B., 2004b, Eolian dust and the origin of sedimentary chert: U. S. Geological Survey Open-file Report 2004-1098, 13 p., accessed July 29, 2011, at http://pubs.usgs.gov/of/2004/1098/2004-1098.pdf.

Cecil, C.B., 2009, An empirical paleoclimate model for the origin of Carboniferous strata in North America [abs.]: Geological Society of America Abstracts with Programs, Paper No. 163-11, accessed July, 29, 2011, at http://gsa.confex.com/gsa/2009AM/finalprogram/abstract_161590.htm.

Cecil, C.B., Ahlbrandt, T.S., and Heald, M.T., 1991, Paleoclimatic implications for the origin of Paleozoic quartz arenites in the Appalachian basin [abs.]: Geological Society of America Abstracts with Programs, v. 23, no. 5, p. A72.

Cecil, C.B., Brezinski, D.K., and Dulong, F.T., 2004, The Paleozoic record of changes in global climate and sea level: central Appalachian basin, in Southworth, Scott, and Burton, William, eds., Geology of the national capital region - field trip guidebook: U.S. Geological Survey Circular 1264, Chapter 3, p. 78-135, accessed July 29, 2011, at http://pubs.usgs.gov/circ/2004/1264/pdf/trip3.pdf.

Clark, S.H.B., and Mosier, E.L., 1989, Barite nodules in Devonian shale and mudstone of western Virginia: U.S. Geological Survey Bulletin 1880, 30 p.

Cook, T.D., and Bally, A.W., eds., 1975, Stratigraphic atlas of North and Central America: Princeton, N.J., Princeton University Press, 272 p.

Cooper, B.N., 1939, Geology of the Draper Mountain area, Virginia: Virginia Geological Survey Bulletin 55, 98 p.

de Witt, Wallace, Jr., Roen, J.B., and Wallace, L.G., 1993, Stratigraphy of Devonian black shales and associated rocks in the Appalachian Basin, in Roen, J.B., and Kepferle, R.C., eds., Petroleum geology of the Devonian and Mississippian black shale of eastern North America: U.S. Geological Survey Bulletin 1909, p. B1-B57. 
Dennison, J.M., 1988, Field trip road log: Devonian delta east-central West Virginia and adjacent Virginia: American Association of Petroleum Geologists Eastern Section Meeting, Geologic field guide, p. 96-145.

Dennison, J.M., 2005, Geologic field guide to Devonian stratigraphy and hydrocarbon geology near U.S. Route 250 in West Virginia and Virginia: American Association of Petroleum Geologists Eastern Section Meeting 2005, 187 p.

Dennison, J.M., and Head, J.W., 1975, Sea level variations interpreted from the Appalachian basin Silurian and Devonian: American Journal of Science, v. 275, p. 1089-1120.

Dicken, C.L., Nicholson, S.W., Horton, J.D., Kinney, S.A., Gunther, Gregory, Foose, M.P., and Mueller, J.A.L., 2005, Preliminary integrated geologic map databases for the United States: Delaware, Maryland, New York, Pennsylvania, and Virginia: U.S. Geological Survey OpenFile Report 2005-1325, accessed June 28, 2010, at http://pubs.usgs.gov/of/2005/1325/.

Diecchio, R.J., 1985, Regional controls of gas accumulation in Oriskany Sandstone, central Appalachian basin: American Association of Petroleum Geologists Bulletin, v. 69, p. 722-732. Dorobek, S.L., and Read, J.F., 1986, Sedimentology and basin evolution of the Siluro-Devonian

Helderberg Group, central Appalachians: Journal of Sedimentary Petrology, v. 56, p. 601-613. Engelder, Terry, and Whitaker, Amy, 2006, Early jointing in coal and black shale: Evidence for an Appalachian-wide stress field as a prelude to the Alleghanian orogeny: Geology, v. 34, p. 581-584.

Flaherty, K.J., 1996, Play Dho: Fractured Middle Devonian Huntersville Chert and Lower Devonian Oriskany Sandstone, in Roen, J.B., and Walker, B.J., eds., 1996, The atlas of major Appalachian gas plays: West Virginia Geological and Economic Survey Publication V-25, p. 103-108.

Grabau, A.W., 1940, The rhythm of the ages: Peking, China, Henri Vetch, 561 p.

Hall, James, 1839, Third annual report of the fourth geological district of the State of New York:

New York Geological Survey Annual Report, p. 287-339.

Harris, A.G., Stamm, N.R., Weary, D.J., Repetski, J.E., Stamm, R.G., and Parker, R.A., 1994, Conodont color alteration index (CAI) map and conodont-based age determinations for the Winchester 30' x 60' quadrangle and adjacent area, Virginia, West Virginia, and Maryland: U.S. Geological Survey Miscellaneous Field Studies Map and Report MF-2239, 40 p., 1 sheet.

Hasson, K.O., and Dennison, J.M., 1968, Relation of type Millboro Shale in Virginia to Romney Group (Devonian) of West Virginia and Maryland: Geological Society of America Special Paper 115, p. 476-477.

Hasson, K.O., and Dennison, J.M., 1988, Devonian shale lithostratigraphy, central Appalachians, U.S.A., in McMillan, N.J., Embry, A.F., and Glass, D.J., eds., Devonian of the world: Proceedings of the Second International Symposium on the Devonian System: Canadian Society of Petroleum Geologists Memoir 14, v. 2, p. 157-177.

Haynes, J.T., and Whitmeyer, S.J., 2010, Geologic map of the north half of the Williamsville 71/2 minute quadrangle, Highland and Bath Counties, Virginia: unpublished geologic map submitted to Educational Component of the National Cooperative Geologic Mapping Program (EDMAP), U.S. Geological Survey.

Hill, D.G., and Lombardi, T.E., 2002, Fractured gas shale potential in New York: Report prepared for the New York State Energy Research and Development Authority; accessed July 29, 2011, at http://esogis.nysm.nysed.gov/esogisdata/downloads/NYSERDA/5012/Fractured\%20Gas\%20Sh ale\%20Potential\%20in\%20New\%20York/Fractured\%20Gas\%20Shale\%20Potential\%20in\%2 oNew\%20York.pdf. 
Kulander, B.R., and Dean, S.L., 1986, Structure and tectonics of central and southern

Appalachian Valley and Ridge and Plateau Provinces, West Virginia and Virginia: American Association of Petroleum Geologists Bulletin, v. 70, p. 1674-1684.

Lesure, F.G., 1957, Geology of the Clifton Forge iron district, Virginia: Bulletin of the Virginia Polytechnic Institute, Engineering Experiment Station Series No. 118, v. 50, no. 7, 130 p.

Limerick, Samuel, Luo, Lucy, Long, Gary, Morehouse, David, Perrin, Jack, Jackson, Steve, and King, Robert, 2005, Appalachian basin, eastern West Virginia (Panel 5 of 7), oil and gas fields by 2001 gas reserve class: U.S. Department of Energy, Energy Information Administration, 1 sheet.

Lundegard, P.D., Samuels, N.D., and Pryor, W.A., 1985, Upper Devonian turbidite sequence, central and southern Appalachian basin: contrasts with submarine fan deposits, in Woodrow, D.L., and Sevon, W.D., eds., The Catskill Delta: Geological Society of America Special Paper 201, p. 107-121.

McDowell, R.R., Britton, J.Q., Avary, K.L, Matchen, D.L., Diecchio, R.J., Hicks, K.E., Walkup, L.C., Burns, M.S., and Waggy, P.J., 2007, Bedrock geologic map of the Fort Seybert 7.5' quadrangle, West Virginia: West Virginia Geological and Economic Survey Open File Map OF-0408, 1 sheet.

Milici, R.C., and Swezey, C.S., 2006, Assessment of Appalachian Basin oil and gas resources: Devonian Shale-Middle and Upper Paleozoic Total Petroleum System: U.S. Geological Survey Open-File Report 2006-1237, 70 p.

Nicholson, S.W., Dicken, C.L., Horton, J.D., Labay, K.A., Foose, M.P., and Mueller, J.A.L., 2005, Preliminary integrated geologic map databases for the United States: Kentucky, Ohio, Tennessee, and West Virginia: U.S. Geological Survey Open-File Report 2005-1324, accessed June 28, 2010, at http://pubs.usgs.gov/of/2005/1324/.

Nuelle, L.M., and Shelton, K.L., 1986, Geologic and geochemical evidence of possible bedded barite deposits in Devonian rocks of the Valley and Ridge province, Appalachian Mountains: Economic Geology, v. 81, p. 1408-1430.

Patchen, D.G., 1968, Oriskany Sandstone-Huntersville Chert gas production in the eastern half of West Virginia: West Virginia Geological and Economic Survey Circular 9, 30 p.

Rader, E.K., and Gathright, T.M., II, 2001, Geologic map of the Front Royal 30 x 60 minute quadrangle: portions of Clarke, Page, Rockingham, Shenandoah, and Warren Counties, Virginia: Virginia Division of Mineral Resources Publication 162, color 1:100,000-scale geologic map, 1 sheet.

Rader, E.K., and Wilkes, G.P., 2001, Geologic map of the Virginia portion of the Staunton 30 x 60 minute quadrangle: Virginia Division of Mineral Resources Publication 163, color 1:100,000-scale geologic map, 1 sheet.

Ryder, R.T., Trippi, M.H., Swezey, C.S., Milici, R.C., Repetski, J.E., Ruppert, L.F., and Rowan, E.L., 2011, A regional perspective of the Devonian shale and Ordovician Utica shale total petroleum systems of the Appalachian basin [abs.]: American Association of Petroleum Geologists, Eastern Section 2011 meeting abstracts with program; accessed July 29, 2011, at http://www.gswweb.org/aapg/abstracts/Ryder.pdf.

Scotese, C.S., 2003, Paleomap Project: Web site accessed July 29, 2011, at http://www.scotese.com.

Swezey, C.S., 2008, Regional stratigraphy and petroleum systems of the Michigan basin, North America: U.S. Geological Survey Scientific Investigations Map 2978, 1 sheet, accessed July 29, 2011, at http://pubs.usgs.gov/sim/2978/.

Swezey, C.S., 2009, Regional stratigraphy and petroleum systems of the Illinois basin, U.S.A.: U.S. Geological Survey Scientific Investigations Map 3068, 1 sheet, accessed July 29, 2011, at http://pubs.usgs.gov/sim/3068. 
Vanuxem, Lardner, 1839, New York Geological Survey, Third annual report of the Geological Survey of the third district: New York Geological Survey, Annual Report 1839, p. 273.

Wheeler, R.L., 2002, Distinguishing seismic from nonseismic soft-sediment structures - criteria from seismic-hazard analysis, in Ettensohn, F.R., Rast, N., and Brett, C.E., eds., Ancient seismites: Boulder, Colo., Geological Society of America Special Paper 359, p. 1-11. Willard, Bradford, 1935, Hamilton Group of central Pennsylvania: Geological Society of America Bulletin, v. 46, p. 195-224.

Willard, Bradford, 1939, Middle Devonian, Stroudsburgian Stage, in The Devonian of Pennsylvania: Pennsylvania Geological Survey, $4^{\text {th }}$ Series, Bulletin G19, p. 131-160.

Woodrow, D.L., Dennison, J.M., Ettensohn, F.R., Sevon, W.T., and Kirchgasser, W.T., 1988, Middle and Upper Devonian stratigraphy and paleogeography of the central and southern Appalachians and eastern Midcontinent, in McMillan, N.J., Embry, A.F., and Glass, D.J., eds., Devonian of the world: Canadian Society of Petroleum Geologists Memoir 14, v. 1, p. 277-301.

Woodrow, D.L., and Sevon, W.D., eds., 1985, The Catskill Delta: Geological Society of America Special Paper 201, 246 p.

Young, R.S., and Harnsberger, W.T., 1955, Geology of Bergton gas field, Rockingham County, Virginia: American Association of Petroleum Geologists Bulletin, v. 39, p. 317-328. 